\title{
Article
}

\section{A Common Law for Our Age of Colonialism: The Judicial Divestiture of Indian Tribal Authority over Nonmembers}

\author{
Philip P. Frickey ${ }^{\dagger}$
}

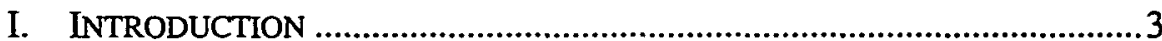

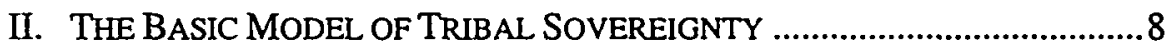

A. Foundational Premises ...............................................................8

B. The Fragility of These Principles in the Context of Non-Indians in Indian Country

III. DIVESTING TRIBAL TERRTTORIAL SOVEREIGNTY BY REDUCING THE TERRTTORY

IV. DIVESTING TRIBAL TERRTTORIAL SOVEREIGNTY BY REDUCING THE SOVEREIGNTY

A. The Foundational Precedent: Williams v. Lee and

Tribal-Court Jurisdiction in Civil Cases Brought by

Nonmembers Against Members. .28

B. Congressional Authorization of Tribal Power ................................31

C. Tribal Criminal Jurisdiction over Nonmembers .............................34

1. Oliphant-Non-Indians and Criminal Jurisdiction ..................34

2. Duro-Nonmember Indians and Criminal Jurisdiction ...........39

$\dagger$ Irving Younger Professor of Law, University of Minnesota. William Eskridge, Daniel Farber, David Getches, Joseph Sax, Joseph Singer, and Mark Van Norman provided valuable comments on an earlier draft. George Mader provided helpful research assistance. Apologies to Guido Calabresi for my title, which borrows from that of his book. A Common Law for the Age of Statutes, and thanks to him as well for the conversation mentioned infra notc 140. 
D. Tribal Civil Regulation of Nonmembers in the Absence of Congressional Approval ................................................43

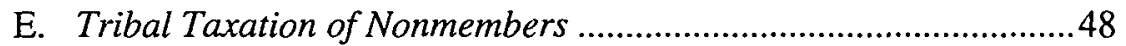

F. Tribal-Court Jurisdiction in Civil Cases Involving Nonmember Defendants ...........................................................51

G. Conclusion..................................................................................57

V. DOING WHAT COMES NATURALlY: METHODOLOGICAL RECONCEPTUALIZATIONS OF THE COURT'S OPINIONS CONCERNING TRIBAL AUTHORITY OVER NONMEMBERS .......................58

A. Judicial Lawmaking in the Guise of Routine Statutory Interpretation ....................................................................58

B. Bringing the Constitution to Indian Country ..................................64

C. Harmonizing Federal Indian Law with the Anglo-American

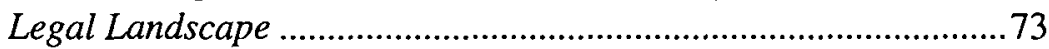

D. The Consequences of Doing What Comes Naturally: Anglocentric Analogical Reasoning................................................78

VI. Conclusion: SOME AlteRnatives to tHe NEW HARMONIZATION OF FEDERAL INDIAN LAW. 


\section{INTRODUCTION}

Surely Oliver Wendell Holmes, Jr. gave federal Indian law no thought when he wrote that "experience"-including "[t]he felt necessities of the time" and "even the prejudices which judges share with their fellowmen"-contributes more "than the syllogism" to the development of judge-made law. ${ }^{1}$ Nor was federal Indian law on his mind when he contrasted an "ideal system of law" based on "science" with the one he inhabited, in which "tradition, or vague sentiment" produced doctrines that were "accidental relics of early notions." 2 Yet his aphoristic analysis strikingly resonates with both sides in a key dispute of federal Indian lawwhether a tribe may regulate all persons within the historical boundary of its reservation-that has produced both incoherent Supreme Court precedents and incandescent controversies in the lives of the people subject to them. Consider an example.

Located in rural South Dakota, the Cheyenne River Sioux Reservation may seem far removed from the great legal controversies of our day. Yet, in less than a decade, it was the setting for two important cases concerning contemporary tribal authority. In the first, Solem v. Bartlett, ${ }^{3}$ the Supreme Court held that reservation borders specified in a nineteenth-century treaty survived the later enactment of a federal statute that opened the reservation for non-Indian homesteading and that has resulted in a significant nonIndian population there. The Court concluded:

When both [the statute] and its legislative history fail to provide substantial and compelling evidence of a congressional intention to diminish Indian lands, we are bound by our traditional solicitude for the Indian tribes to rule that diminishment did not take place and that the old reservation boundaries survived the opening. ${ }^{4}$

As a result, the tribe has potentially significant authority over nonIndian reservation landowners. ${ }^{5}$ At least some of these non-Indians feel betrayed. In their view, Solem ignored their reasonable expectations and those of their predecessors that non-Indian lands were outside the reservation. They complain of being subject to a sovereign in which they have no say, a sort of "taxation without representation" foreign to

1. Oliver Wendell holmes, Jr., The Common Law 1 (Boston, Litule, Brown \& Co. 1881).

2. Oliver Wendell Holmes, JR., Leaming and Science, in Collected LeGal Papers $138,139(1920)$.

3. 465 U.S. 463 (1984).

4. Id. at 472 .

5. See City of Timber Lake v. Cheyenne River Sioux Tribe, 10 F.3d 554 (8th Cir. 1993) (upholding tribal regulation of non-Indian liquor transactions). 
America. ${ }^{6}$ They could invoke Holmes to contend that "tradition, or vague sentiment" - what the Court in Solem called its "traditional solicitude for the Indian tribes" - has produced an "accidental relic" of tribal sovereignty inconsistent both with longstanding congressional and private expectations and with fundamental faimess.

In the second case, South Dakota v. Bourland, ${ }^{7}$ the Court held that the tribe could not regulate non-Indian hunting and fishing in an area where Congress had taken reservation land to build a dam, reservoir, and public recreation area. Even though the land remained within reservation boundaries, the Court concluded that, "when Congress has broadly opened up such land to non-Indians, the effect of the transfer is the destruction of preexisting Indian rights to regulatory control." 8

Bourland and Solem fit together awkwardly in both law and life. Doctrinally, the focus in Bourland on the effect of the congressional alienation of Indian land seems inconsistent with Solem, where the reservation remained intact despite the congressional alienation of Indian land because no clear congressional intent to diminish tribal authority had been shown. As a practical matter, Bourland probably antagonizes tribal members as much as Solem angers non-Indian reservation residents. Because of Bourland, the tribe lacks integrated regulatory authority over its territory. Tribal leaders, too, could invoke Holmes in contending that tribal sovereignty, long recognized by the Supreme Court, was displaced by a one-sided perception of non-Indian "felt necessities" to be free from tribal authority that are rooted in the "prejudices which judges share with their fellow-men [and women]."

The controversy at Cheyenne River is contemporary federal Indian law in microcosm. What the Supreme Court said long ago remains true today: The relation of Indian tribes to the broader American system "has always been an anomalous one and of a complex character." The Constitution does not clearly delineate the relationship among tribes, the federal government, and the states. ${ }^{10}$ It is unsurprising, then, that the task of rationalizing the field has largely fallen to the Supreme Court. Given the

6. A non-Indian resident of the Cheyenne River Reservation put it as follows:

They [the tribe] have no right to tell me what to do-I'm not Indian!... If this were Indian land, it would make sense. But we're a non-Indian town. There is no Indian land here. This is all homestead land, and the tribe was paid for it. I already pay taxes to the State of South Dakota. The tribe doesn't provide us with any services. There's no tribal law enforcement here. I can't vote in tribal elections or on anything else that happens on the reservation. What they're talking about is taxation without representation.

FERGUS M. BORDEWICH, KILLING THE WHITE MAN'S INDIAN 97 (1996).

7. 508 U.S. 679 (1993).

8. Id. at 692 .

9. United States v. Kagama, 118 U.S. 375, 381 (1886).

10. The Constitution mentions Indians only three times. Congress may regulate commerce "with the Indian Tribes," U.S. CoNST. art. I, § 8, cl. 3, and "Indians not taxed" are not counted when apportioning the House of Representatives, id. $\S 2$, cl. 3 ; id. amend. XIV, $\$ 2$. 
lack of guidance in positive law, the complexity of the issues, and the tangled normative questions surrounding the colonial displacement of indigenous peoples to construct a constitutional democracy, it is also not surprising that the resulting decisional law is as incoherent as it is complicated. ${ }^{11}$

As the Cheyenne River cases indicate, one of the most vexing clusters of questions involves the geographical extent of reservations containing many non-Indians and the authority of tribes to regulate nonmembers found in "Indian country." 12 Over the past four decades, the Supreme Court has decided six cases concerning reservation boundaries in addition to Solem. ${ }^{13}$ Although the cases purport to follow Solem's injunction that only clear congressional intent may work a reduction in reservation size, Part III demonstrates that their results cannot be squared with that standard. As Part IV documents, over the same period the Court has decided the remarkable number of fourteen cases involving tribal criminal, civil, and judicial authority over nonmembers found on reservations. ${ }^{14}$ Tribes prevailed in two seemingly easy cases - considering whether Congress could authorize tribal civil regulation of nonmembers ${ }^{15}$ and whether a tribe could tax the sale of a product to a nonmember ${ }^{16}$-as well as in three more controversial settings. ${ }^{17}$

11. See, e.g., Philip P. Frickey, Adjudication and lis Disconsents: Coherence and Conciliation in Federal Indian Law, 110 HARV. L. REV. 1754 (1997).

12. A federal criminal statute defines "Indian country" as

(a) all land within the limits of any Indian reservation under the jurisdiction of the United States government, notwithstanding the issuance of any patent, and, including rights-of-way running through the reservation, (b) all dependent Indian communities within the borders of the United States whether within the original or subsequently acquired territory thereof, and whether within or without the limits of a state, and (c) all Indian allotments, the Indian titles to which have not been extinguished, including rights-of-way running through the same.

18 U.S.C. $\$ 1151$ (1994). The Supreme Court has borrowed this definition for civil cases as well. See DeCoteau v. District County Court 420 U.S. 425,427 n.2 (1975).

13. See South Dakota v. Yankton Sioux Tribe, 118 S. C. 789 (1998); Hagen v. Utah, 510 U.S. 399 (1994); Rosebud Sioux Tribe v. Kneip, 430 U.S. 584 (1977); DeCoteatu, 420 U.S. 425; Mattz v. Amett, 412 U.S. 481 (1973); Seymour v. Superintendent, 368 U.S. 351 (1962).

14. See El Paso Natural Gas Co. v. Neztsosie, 119 S. C. 1430 (1999): Strate v. A-1 Contractors, 520 U.S. 438 (1997); South Dakota v. Bourland, 508 U.S. 679 (1993); Duro v. Reina, 495 U.S. 676 (1990); Brendale v. Confederated Tribes \& Bands of the Yakima Indian Nation, 492 U.S. 408 (1989); Iowa Mut. Ins. Co. v. LaPlante, 480 U.S. 9 (1987); National Farmers Union Ins. Cos. v. Crow Tribe, 471 U.S. 845 (1985); Kerr-McGee Corp. v. Navajo Tribe, 471 U.S. 195 (1985); Merrion v. Jicarilla Apache Tribe, 455 U.S. 130 (1982): Montana v. United States, 450 U.S. 544 (1981); Washington v. Confederated Tribes of the Colville Reservation. 447 U.S. 134 (1980); Oliphant v. Suquamish Indian Tribe, 435 U.S. 191 (1978); United States v. Mazuric, 419 U.S. 544 (1975); Williams v. Lee, 358 U.S. 217 (1959).

15. See Mazurie, 419 U.S. 544; infra text accompanying notes 148-162.

16. See Confederated Tribes, 447 U.S. 134; infra text accompanying notes 240-243.

17. Williams held that an action brought by a nonmember against a member to collect on a debt incurred in Indian country must be heand in tribal cour. For a discussion of Williams, see infra text accompanying notes 133-147. Kerr-McGee and Merrion upheld tribal power to impose a severance tax upon a non-Indian company extracting minerals from tribal land. For discussion of Merrion, see infra text accompanying notes 244-250; for a discussion of Kerr-McGee, see infra note 248. 
Three other cases reached peculiar compromises. ${ }^{18}$ The other six decisions diminished the tribal capacity to deal with nonmembers who fail to comply with reservation law. Are these opinions defeats for legitimate tribal authority, a kind of ongoing judicial colonization in Indian country? Or do they reflect a proper respect for the civil rights of American citizens who, because they cannot participate in tribal government or serve on tribal juries and are not members of the ethnic group exercising sovereign authority, lack the actual and virtual representation that provides the customary nonjudicial protection from governmental abuse in the United States? ${ }^{19}$ Moreover, whatever might be the appropriate normative conclusions about these decisions, do they fit together into a conceptual whole or disaggregate into incoherence?

This Article examines the concept of tribal sovereignty that was originally developed by the Supreme Court and that has evolved as the result of clashes with the interests of nonmembers. Part II traces the traditional model of tribal authority, which at least implicitly assumed that tribes have geographical sovereignty over their reservations and all persons found there. In recent years, the Supreme Court has undercut this understanding in two fundamental ways. As Part III demonstrates, the Court has sometimes reduced tribal geographical sovereignty by diminishing reservation boundaries to free largely non-Indian areas from tribal control. As Part IV documents, the Court has also substantially undermined tribal authority even within acknowledged reservation borders by concluding that tribes have no criminal, and only limited civil, jurisdiction over nonmembers found there. ${ }^{20}$

On the surface, the analysis in Parts III and IV seems to reveal an incoherence between the outcomes of these decisions and their purported doctrinal underpinnings. Part $\mathrm{V}$ suggests, however, that an unstated

18. The Court reached an odd 4-2-3 split in the Brendale case, with the outcomes on the issues controlled by the two-Justice swing faction. See infra text accompanying notes 222-230. In National Farmers Union Insurance Cos. and Iowa Mutual, the Court appeared to create a presumption favoring tribal-court jurisdiction over civil cases brought by a tribal member against a nonmember on a cause of action arising in Indian country. In Strate, however, a case arising on non-Indian land, the Court deviated from that approach and understood the earlier cases as simply sometimes requiring such a nonmember defendant to exhaust tribal-court remedies before seeking federal judicial relief against the tribal-court action. See infra text accompanying notes 254-277. For a discussion of Neztsosie, the most recent decision on tribal-court jurisdiction, see infra note 277.

19. See generally JOHN HART ELY, DEMOCRACY AND DISTRUST: A THEORY OF JUDICIAL REVIEW 77-101 (1980) (arguing that the Federal Constitution assumes a process of representative government that presumptively provides adequate actual and virtual representation of citizens).

20. For an earlier recognition of these strategies, see Robert Laurence, The Dominant Society's Judicial Reluctance To Allow Tribal Civil Law To Apply to Non-Indians: Reservation Diminishment, Modern Demography and the Indian Civil Rights Act, 30 U. RICH. L. REV. 781 (1996) [hereinafter Laurence, Judicial Reluctance]; and Robert Laurence, The Unseemly Nature of Reservation Diminishment by Judicial, as Opposed to Legislative, Fiat and the Ironic Role of the Indian Civil Rights Act in Limiting Both, 71 N.D. L. REV. 393 (1995). 
assumption underlies all of them: Tribal sovereignty over non-Indian areas and tribal authority to regulate significant nonmember interests are inconsistent with what the Supreme Court presumes to be the wishes of Congress. Because in these cases the congressional intent is unstated, however, the outcomes turn on judicial presumptions, rather than legislative resolutions, concerning the question whether tribes are sovereigns or merely membership organizations. Thus, it is the Court, not Congress, that has exercised front-line responsibility for the vast erosion of tribal sovereignty. The coherence that underlies the doctrinal confusion in the cases is a strong, albeit largely unarticulated and undefended, judicial aversion to basic claims of tribal authority over nonmembers that is implicitly projected upon Congress as well.

That the Court has exercised this extraordinary authority in an area in which Congress has long operated with plenary power ${ }^{21}$ supports the disturbing conclusion that the Court has assumed a legislative functionthat of implementing the ongoing colonial process. 22 Part $\mathrm{V}$ suggests that the Court has done so by flattening federal Indian law into the broader American public law by importing general constitutional and subconstitutional values into the field. The Court has undertaken this task without congressional guidance. A half-millennium after the colonial process began, in our time of great skepticism concerning colonization, ${ }^{23}$ our least democratic branch has become our most enthusiastic colonial agent.

The primary purpose of this Article is to engage in a wide-ranging and open-minded exploration of the contemporary Supreme Court's consideration of tribal sovereignty. I have attempted to be generous to the Court in searching for descriptive coherence and normative support for its work, even when that leads to conclusions inconsistent with my views supporting tribal sovereignty. In doing so, I articulate a variety of possible coherentist interpretations of the decisional law. This speculative and polite search for coherence should not be confused with either doctrinal reality or normative attractiveness. Indeed, as I shall explain, my speculations not only have descriptive problems associated with them-they are often in great tension with precedent and broader legal principles-but they are rooted as well in a normatively unattractive judicial colonial impulse beneath the dignity of the best qualities of federal Indian law. Ultimately, I

21. See infra text accompanying notes $48-53$.

22. For earlier commentary critical of the Coure in this respect, see Philip P. Frickey. Marshalling Past and Present: Colonialism, Constinutionalism, and Interpretation in Federal Indian Law, 107 HARV. L. REV. 381, 422-26, $432-39$ (1993): and David H. Getches, Conquering the Cultural Frontier: The New Subjectivism of the Supreme Court in Indian Law, 84 CAL. L. REV. 1573, 1575 (1996).

23. See, e.g., Philip P. Frickey, Domesticating Federal Indian Law, 81 MINN. L. REv. 31,76 \& n.177 (1996) (summarizing the decolonization movement in the international community). 
conclude that the law remains muddled in many respects. What I identify is more an unreflective judicial trend rooted in apparent uneasiness with tribal authority than a paradigmatic, entrenched doctrinal shift. Especially because the Court has paid little attention to the tension between longstanding principles of federal Indian law and the contemporary judicial drift away from them, there remains room for future elaborations ratifying meaningful tribal authority. Nonetheless, my account raises significant questions concerning whether the contemporary Court is likely to embrace an approach to federal Indian law that is both doctrinally coherent and normatively defensible. Accordingly, Part VI considers the roles that other actors might play in circumventing this judicial trend.

\section{THE BASIC MODEL OF TRIBAL SOVEREIGNTY}

\section{A. Foundational Premises}

Questions concerning tribal power are, of course, not new. In his monumental attempt to systematize federal Indian law, Felix Cohen addressed the place of tribal power within the American scheme of governance. ${ }^{24}$ Cohen concluded that " $[t]$ he whole course of judicial decision" 25 adhered to three basic principles. First, prior to European contact, a tribe possessed "all the powers of any sovereign state." ${ }^{26}$ Second, the European colonial process, which Cohen labeled "[c]onquest,"

renders the tribe subject to the legislative power of the United States and, in substance, terminates the external powers of sovereignty of the tribe, e.g., its power to enter into treaties with foreign nations, but does not by itself affect the internal sovereignty of the tribe, i.e., its powers of local self-government. ${ }^{27}$

Third, tribes therefore retain internal sovereignty "subject to qualification by treaties and by express legislation of Congress." ${ }^{28}$ Thus, tribal powers generally are not "delegated powers granted by express acts of Congress," but instead are "inherent powers of a limited sovereignty which has never been extinguished." ${ }^{29}$ Consistently with established canons of

24. See FELIX S. COHEN, HANDBOOK OF FEDERAL INDIAN LAW (1941). On Cohen's jurispndence in general and in federal Indian law in particular, see Stephen M. Feldman. Felix $S$. Cohen and His Jurisprudence: Reflections on Federal Indian Law, 35 BuFF. L. REV. 479 (1986). Probably his most famous jurisprudential writing is Felix S. Cohen, Transcendental Nonsense and the Functional Approach, 35 CoLUM. L. REV. 809 (1935).

25. COHEN, supra note 24 , at 123.

26. Id.

27. Id. (footnote omitted).

28. Id.

29. Id. at 122 (emphasis omitted). 
interpretation, ${ }^{30}$ ambiguities in federal statutes that might be read as invading tribal authority are construed narrowly to protect tribal interests." Similarly, provisions of Indian treaties that might undercut tribal authority are also read narrowly, based on two key assumptions: The treaty transaction was a cession of rights by the tribe rather than a granting of rights by the United States, ${ }^{32}$ and these cessions, along with all other treaty provisions, are to be interpreted as the Indians would have understood them. ${ }^{33}$

Cohen's synthesis was rooted in two eras of Supreme Court decisionmaking. ${ }^{34}$ In the early nineteenth century, the Marshall Court developed most of the foundational principles of federal Indian law in a trio of cases. In Johnson v. McIntosh ${ }^{35}$ Chief Justice Marshall's opinion for the Court concluded that, upon "discovery" by Europeans, tribes lost their status as complete sovereigns and, in particular, their ability to engage in external relations with any sovereign other than the European discovering country. ${ }^{36}$ Marshall then explained, in Cherokee Nation v. Georgia, ${ }^{37}$ that

30. For modern examinations, see Frickey, supra note 22; and Charles F. Wilkinson \& John M. Volkman, Judicial Review of Indian Treaty Abrogation: "As Long as Water Flows, or Grass Grows upon the Earth"-How Long a Time Is Thar?, 63 CAL. L. REV. 601 (1975).

31. See COHEN, supra note 24 , at 122.

32. See id.

33. See id. at 37. Taken together, these concepts require an inquiry into whether the Indians understood that they were ceding away a particular interest, rather than whether the United States understood that it was granting that interest to the tribe or whether the language of the treaty provided any seemingly objective answer to this question.

34. By this I do not mean that Cohen's treatise presented some objective, detached synthesis of easily derived principles. Because federal Indian law is notoriously incoherent, it has been especially subject to conceptual molding. As Felix Frankfurter wrote in honor of Cohen's treatise, "Only a ripe and imaginative scholar with a synthesizing faculty would have brought luminous order out of such a mish-mash." Felix Frankfurter, Foreword to Felix S. Cohen. Dialogue on Private Property, 9 RuTGERs L. REv. 355, 356 (1954). Indeed, Cohen forthrightly acknowledged the normative spirit animating his work:

What has made this work possible, in the final analysis, is a set of beliefs that form the intellectual equipment of a generation-a belief that our treatment of the Indian in the past is not something of which a democracy can be proud, a belief that the protection of minority rights and the substitution of reason and agreement for force and dictation represent a contribution to civilization, a belief that confusion and ignorance in fields of law are allies of despotism, a belief that it is the duty of the Government to aid oppressed groups in the understanding and appreciation of their legal rights. a belief that understanding of the law, in Indian fields as elsewhere, requires more than textual exegesis, requires appreciation of history and understanding of cconomic. political. social, and moral problems.

COHEN, supra note 24 , at xviii. Nonetheless, as Harold Ickes wrote in his foreword to the Handbook, "Whatever legal force [the Handbook] will have must be derived from the original authorities which have been assiduously gathered and patiently analyzed." Harold L. Ickes, Foreword to id. at v, vi. As the discussion in the text indicates, the basic principles that I have taken from Cohen had significant precedential grounding.

35. 21 U.S. (8 Wheat.) 543 (1823).

36. In Johnson, Marshall stated that a tribe was locked into an exclusive sovereıgn-tosovereign relationship with the discovering European country, such that it could engage in treaty relations and land transactions only with the representatives of that country. See id. at 573.

37. 30 U.S. (5 Pet.) 1 (1831). 
although tribes had no sovereignty in an international sense, they retained some governmental authority within the United States. ${ }^{38}$ Marshall labeled the tribes "domestic dependent nations" 39 in a relationship with the United States that "resembles that of a ward to his guardian." 40 Finally, in Worcester v. Georgia ${ }^{4}$ - the most important decision in federal Indian law-Marshall concluded that, because the federal-tribal relationship was exclusive, states had no role in Indian country. Marshall analogized the relationship between tribes and the United States to that between a weaker sovereign and a stronger, supporting sovereign under international law. ${ }^{42}$ To be sure, a tribe could cede away power or property by treaty, but Marshall adopted canons of interpretation that require clarity before courts may conclude that a tribe has in fact given up valuable rights. ${ }^{43}$ Absent any clear treaty cession or congressional act, a tribe retained territorial sovereignty over its reservation. ${ }^{44}$

At the end of the nineteenth century, the Court made it even clearer that tribal authority is generally inherent and retained. Talton v. Mayes ${ }^{45}$ held that the Constitution did not apply to the grand jury indictment process adopted by the Cherokee Nation to prosecute its members in tribal court. The police powers of the tribe were not "Federal powers created by and springing from the Constitution," 46 but rather "existed prior to the Constitution" ${ }^{47}$ and amounted to retained, inherent sovereignty free from

38. Marshall stated that " [s]o much of the argument as was intended to prove the character of the Cherokees as a state, as a distinct political society, separated from others, capable of managing its own affairs and governing itself, has, in the opinion of a majority of the judges, been completely successful." Id. at 16. In Cherokee Nation, Marshall wrote for only one other Justice (McLean); two other Justices (Thompson and Story) concluded in dissent that the tribe was a foreign state, and the other two Justices participating (Johnson and Baldwin) thought that it possessed no sovereignty at all. Marshall's opinion was, therefore, something of a middle ground. and it is relied upon today despite its lack of complete precedential value. See, e.g., Alaska v. Native Village of Venetie Tribal Gov't, 118 S. Ct. 948, 954 n.5 (1998); Oklahoma Tax Comm'n v. Citizens Band of Potawatomi Indian Tribe, 498 U.S. 505, 509 (1991).

39. Cherokee Nation, 30 U.S. at 17.

40. Id.

41. 31 U.S. (6 Pet.) 515 (1832).

42. See id. at 561 .

43. Marshall understood the treaty transaction to be a ceding of rights by the tribe, not a granting of rights by the United States, with the key question being what the Indians thought they were giving up. See id. at 552-53. He also assumed that the purpose of the treaty was to promote peace rather than to "annihilat[e] the political existence of one of the parties," and stated that the contrary conclusion could be supported only by "openly avowed" treaty language. Id. at 554 . On Marshall's interpretive strategies, see Frickey, supra note 22, at 384-417.

44. Marshall wrote:

The Cherokee nation, then, is a distinct community occupying its own territory. with boundaries accurately described, in which the laws of Georgia can have no force, and which the citizens of Georgia have no right to enter, but with the assent of the Cherokees themselves, or in conformity with treaties, and with the acts of congress.

Worcester, 31 U.S. (6 Pet.) at 561.

45. 163 U.S. $376(1896)$.

46. Id. at 382 .

47. Id. at 384 . 
federal constitutional constraint. Taken together, Worcester and Talton constitute the conceptual high-water mark of tribal sovereignty in federal Indian law and, as Parts III and IV indicate, remain formidable precedents antagonistic to modern judicial efforts to undercut tribal authority.

At the turn of the century, the Court also clarified the final element of Cohen's three principles concerning tribal sovereignty: the role of congressional authority to diminish tribal power. In Lone Wolf $v$. Hitchcock, ${ }^{48}$ the Court concluded that Congress had "[p]lenary authority over the tribal relations of the Indians," 49 a power that the Court deemed "a political one, not subject to be controlled by the judicial department of the government." 50 Although the implication that exercises of congressional power over Indian affairs are nonjusticiable political questions has not survived more recent cases, ${ }^{51}$ the Court continues to refer to the "plenary power" of Congress over Indian affairs. ${ }^{52}$ Indeed, the Court has never invalidated a federal statute on the ground that it invaded tribal authority. ${ }^{33}$

In addition to being rooted in precedent, Cohen's three principles represented a normative accommodation of our colonial heritage and a judicial respect for tribal survival as a self-governing authority. The principles accept the inevitable: The United States resulted from a colonial process that cannot be undone at this late date, no matter the normative concerns that might be raised about it. Thus, in light of "the actual state of things," 54 courts viewed themselves as impotent to consider basic challenges to historical colonization, such as the involuntary loss of tribal authority to engage in government relations and land transactions with any entity other than the United States and the presumed supremacy of Congress over Indian affairs. Moreover, tribes themselves had ceded away other important interests on a treaty-by-treaty basis. Despite these factors,

48. 187 U.S. 553 (1903).

49. Id. at 565 .

50. Id.; see also United States v. Sandoval, 231 U.S. 28, 34 (1913) (holding that Congress's plenary power extends even to Indians who are citizens and who hold property in fee simple): United States v. Kagama, 118 U.S. 375,380 (1886) (holding that Congress may criminalize even purely intratribal misconduct on the reservation).

51. See, e.g., United States v. Sioux Nation of Indians, 448 U.S. 371 (1980); Delaware Tribal Bus. Comm. v. Weeks, 430 U.S. 73 (1977).

52. See, e.g., Cotton Petroleum Corp. v. New Mexico, 490 U.S. 163, 192 (1989).

53. The most recent case striking down a federal statute involving Indian affairs, Babbint $v$. Youpee, 519 U.S. 234 (1997), and three earlier cases, Hodel v. Inving. 481 U.S. 704 (1987). Choate v. Trapp, 224 U.S. 665 (1912), and Jones v. Meehan, 175 U.S. I (1899), involved interference with individual Indian property rights. Cf. Sioux Nation of Indians, 448 U.S. 371 (upholding an award of just compensation for the taking of the Black Hills). Seminole Tribe $v$. Florida, 517 U.S. 44 (1996), invalidated a statutory provision on Eleventh Amendment grounds. Muskrat v. United States, 219 U.S. 346 (1911), invalidated a statute because it called upon courts to issue advisory opinions.

54. Johnson v. McIntosh, 21 U.S. (8 Wheat.) 543. 591 (1823). 
however, and in the face of the historical justifications for colonization, ${ }^{55}$ the Supreme Court had assumed that the relationship between the colonizers and the tribes was benign, one of trust and cooperation rather than of annihilation. ${ }^{56}$ Thus, treaties were viewed as solemn agreements between cooperative sovereigns under which the tribe, not the federal government, granted rights, which as in derogation of their own sovereignty should be narrowly construed. So, too, although Congress had the authority to destroy Indian rights, the assumption was that Congress would not do so lightly, and thus canons of interpretation protecting tribal interests were applied to statutory as well as treaty interpretation. ${ }^{57}$

These principles combine to form an institutionally sensitive approach to the ongoing American colonial process-the centuries-old but continuing series of conflicts between indigenous peoples and those elements of the dominant society seeking to displace their institutions and prerogatives. ${ }^{58}$ Under the canons of interpretation, positive law on the books (treaties, statutes, and so on) is construed narrowly to preserve tribal sovereignty against all but crystal-clear losses. This technique forces opponents of tribal power to bear the heavier burden in litigation-they must marshal the complexities of the case persuasively - and leaves the reviewing court a simple way to cut through the confusions of federal Indian law. If, as should often occur, tribal authority survives this challenge, its opponents then must bear the burden of legislative inertia. Although Congress may change the outcome, it may do so only openly, by clear statutory language that should flag the issue for legislators and lobbyists who favor Indian interests and that should ensure a fairer legislative fight. Because it is much easier to kill legislation than to enact it, ${ }^{59}$ tribal interests have significant advantages in the legislative struggle. Thus, the courts place significant side constraints on the imposition of new colonial intrusions while leaving the

55. In Johnson, Marshall acknowledged several such justifications-civilizing and Christianizing the Indians, see id. at 573, and promoting economic progress by authorizing "agriculturalists, merchants and manufacturers... to expel hunters from the territory they possess," id. at 588-but refused to become embroiled in the controversy over whether these rationales could justify colonization, see id. at 589 .

56. See Worcester v. Georgia, 31 U.S. (6 Pet.) 515, 546-47 (1832) (asserting that the European discovering countries did not generally interfere with internal tribal matters and obtained Indian lands and political allegiances by purchase, not by coercion); see also id. at 554 (stating that an Indian treaty represented a sovereign-to-sovereign peace agreement, not an act "annihilating the political existence of one of the parties").

57. See, e.g., Choate, 224 U.S. at 675-76, 678.

58. Here I borrow from my earlier commentary. See Frickey, supra note 22, at 416, 428-32. 438; see also Getches, supra note 22, at 1573-74, 1581-93, 1652-55 (describing and urging the retention of "foundation principles" of federal Indian law).

59. See, e.g., KAY LEHMAN SCHLOZMAN \& JOHN T. TIERNEY, ORGANIZED INTERESTS AND AMERICAN DEMOCRACY 314-15, 395-96, 398 (1986). 
ongoing issues of the relationship of tribes and the larger society in the hands of Congress. ${ }^{60}$

\section{B. The Fragility of These Principles in the Context of Non-Indians in Indian Country}

Under these principles, tribes possess all authority not lost as a result of original European contact, explicit treaty cessions, or unambiguous unilateral congressional action. Accordingly, absent treaty or statutory language to the contrary, non-Indians found on an Indian reservation would seem to be subject to tribal authority. Moreover, all three of these categories have significant limiting principles that further undercut any non-Indian immunity to tribal regulation.

As defined by the Marshall Court, the first category concerns the loss of authority to have government relations and land transactions with any entity other than the "discovering" European sovereign or its successor, the United States. It reflects the essential premises necessary to rationalize colonization from its outset and to promote the efficient displacement of indigenous interests on an ongoing basis. Under these assumptions, the colonial process is bilateral, involving subordinated tribes locked into an exclusive relationship with the dominant United States. The non-Indian side of the process is centralized in Congress, which is empowered to carry out the colonization of the continent. Thus, when a diminished tribal authority is traceable to this category, the reason is that the tribal power in question is inconsistent with the capacity of Congress to engage in efficient colonization. The rights of private individuals-such as non-Indians found in Indian country-are, accordingly, irrelevant.

Johnson v. McIntosh, ${ }^{61}$ the case establishing this category, makes this clear. Johnson held that, when a tribe allegedly transferred land to a nonIndian without the consent of the United States, and thus in violation of basic colonial assumptions, the putative purchaser received no rights cognizable in American courts. ${ }^{62}$ Instead, the Court concluded that the tribe had validly conveyed the Indian title when it later transferred the land to the United States. ${ }^{63}$ The best that the Court could do for the successors to the alleged first purchaser was to suggest that they approach the tribe and seek any relief available under tribal law. ${ }^{64}$ Thus, Johnson indicates that, in the

60. For my take on the limits on the supposed plenary power of Congress over Indian affairs, see Frickey, supra note 23. For a thorough overview of these issues, see Nell Jessup Newton, Federal Power over Indians: Its Sources, Scope, and Limitations, 132 U. PA. L. REV. 195 (1984).

61. 21 U.S. (8 Wheat) 543 (1823).

62. See id. at 587-89.

63. See id.

64. See id. at 593. 
absence of federal protection rooted in treaty or statute, non-Indians who enter Indian country must take tribal law as they find it. ${ }^{65}$

The other two categories of diminished tribal authority are, at least in theory, substantially confined as well. As mentioned above, the canons of interpretation require a clear statement in a treaty or statute before tribal interests are deemed lost. As described earlier, ${ }^{66}$ the Court's opinion in Solem refusing to find a diminishment of the boundaries of the Cheyenne River Sioux Reservation demonstrates both the outcome-determinative potential of these canons and their survival into modern-day jurisprudence.

When these three categories are examined together, then, it would seem inescapable that tribes retain territorial sovereignty over their reservations unless some federal treaty or statute has plainly abrogated it. Absent clear immunity in such positive law, non-Indians who find themselves on an Indian reservation would seem to be subject to the authority of the tribe, just as they would be subject to the authority of New York when strolling across Central Park. That is not how the law has turned out, however. As Part III demonstrates, the canons have lost much of their bite in the context of tribal regulation of nonmembers. As Part IV documents, the Court has also undermined tribal sovereignty by reopening the category of tribal powers that are inconsistent with domestic dependent status and then evaluating nonmember complaints about assertions of tribal authority on a case-by-case basis.

At least two factors explain the fragility of the principles that seemingly mandate tribal geographical sovereignty. First, they were developed in cases contesting the authority of tribes vis-à-vis the federal or state governments or the tribe's own members, not vis-à-vis non-Indians. The conclusion that tribes have authority to regulate non-Indians found on reservations follows logically from these cases, but was not at issue in any of them. The second, related factor is that these understandings were developed against the backdrop of a simple context, in which Indian reservations were perceived to be enclaves for Indians only. Congress shattered that understanding when it adopted the General Allotment Act of $1887,{ }^{67}$ a policy directive that reservations be divided up into allotments for tribal members, with the land left over opened to non-Indian homesteading. Implemented on a tribe-by-tribe basis, the allotment process was designed to assimilate Indians into the larger society. ${ }^{68}$ The allotments were to be

65. For helpful interpretations of Johnson along these lines, see Milner S. Ball, Constitution, Court, Indian Tribes, 1987 AM. B. FouND. RES. J. 3, 23-29; and J. Youngblood Henderson, Unraveling the Riddle of Aboriginal Title, 5 AM. INDIAN L. REV. 75, 93-96 (1977).

66. See supra text accompanying notes 3-4.

67. Dawes General Allotment Act of 1887, ch. 119, 24 Stat. 388 (codified as amended at 25 U.S.C. §§ 331-358 (1994)).

68. For an overview of the allotment process and its contemporary consequences. see Judith V. Royster, The Legacy of Allotment, 27 ARIZ. ST. L.J. 1 (1995). My conclusions in Parts III-V. 
held in trust for a period of time, rendering them inalienable and free from state taxation and providing an opportunity for the allottees to learn western agricultural ways. The theory was that, when the trust period ended and the land was transformed into fee simple status, the Indian owners would be assimilated into the agricultural economy. Reservations would disappear over time, and the "Indian problem" would be solved.

It never turned out that way. Allotment was a disastrous policy. When the allotments became alienable, sometimes much more quickly than originally planned, huge amounts of Indian land were lost through sales and tax foreclosures. ${ }^{69}$ By the 1920 s, it had become clear that allotment was a failure. ${ }^{70}$ In the Indian Reorganization Act of 1934 , Congress embraced this reality, extending the trust period for all remaining allotments in perpetuity and providing that no further allotments be made." Congress did not attempt to undo the effects of allotment, however. ${ }^{72}$

Federal Indian law has not been the same since the allotment era. Because of allotment, many reservations today have a significant nonIndian population and a checkerboard land pattern with non-Indian fee property mixed in with Indian allotments and collective tribal property. Indeed, the demographic diversity in Indian country today is remarkable. At one extreme, over ninety-six percent of the residents of the Navajo reservation are Indian. ${ }^{73}$ At the other extreme, the Port Madison Reservation of the Suquamish Indian Tribe in Washington contained over 2900 nonIndians and only fifty members at the time the tribe engaged in major litigation concerning its authority to regulate nonmembers. ${ }^{74}$

linking the Court's abandonment of undiluted principles of tribal sovereignty to the presence of non-Indians in Indian country as the result of the allotment process, are consistent with those of Royster, supra, at 70-78, and Getches, supra note 22, at 1622-26, as well as those that I articulated in an earlier article, see Philip P. Frickey. Congressional Intent, Practical Reasoning, and the Dynamic Nature of Federal Indian Law, 78 CAL. L. REv. 1137, 1150, 1180-81 (1990).

69. See, e.g., FELIX S. COHEN's HANDBOOK OF FEDERAL INDIAN LAW 138 (R. Strickland et al. eds., 1982).

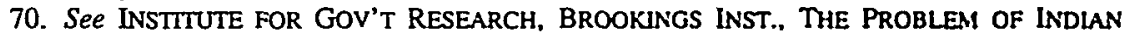
ADMINISTRATION 7, 460-62, 470-72 (Johnson Reprint Corp. 1971) (1928).

71. See Indian Reorganization Act of 1934 , ch. 576,48 Stat. 984 (codified as amended at 25 U.S.C. $\$ \S 461-479$ (1994)).

72. The Court addressed this matter in County of Yakima v. Confederated Tribes \& Bands of the Yakima Indian Nation, 502 U.S. 251 (1992):

Except by authorizing reacquisition of allotted lands in trust, however, Congress made no attempt to undo the dramatic effects of the alloument years on the ownership of former Indian lands. It neither imposed restraints on the ability of Indian allottces to alienate or encumber their fee-patented lands nor impaired the rights of those Id. at 255

non-Indians who had acquired title to over two-thirds of the Indian lands allotied ....

73. See L. Scott Gould, The Congressional Response to Duro v. Reina: Compromising Sovereignty and the Constitution, 28 U.C. DAVIS L. REV. 53, 137 tbl.5 (1994).

74. See Oliphant v. Suquamish Indian Tribe, 435 U.S. 191, 193 n.l (1978). For a discussion of this case, see infra text accompanying notes 163-193. For a quick overview of the demographic diversity in Indian country, see Gould, supra note 73, at 129 tbl.3. 
During the allotment era, another factor also undermined the simple "we/they" context of federal Indian policy. In 1924, Congress unilaterally conferred citizenship upon Indians who had not yet attained that status. ${ }^{75}$ Like it or not, Indians were now citizens of both the United States and their state of residence as well as members of their tribes.

These developments substantially complicate any analysis of contemporary federal Indian law. Where it was once plausible to imagine that the only important relationship in the field was a bilateral one between Congress and the tribes, the interests of individuals--Indian and non-Indian alike-are now salient by virtue of the congressional policies of allotment and Indian citizenship. Nonetheless, the federal policy of promoting tribal sovereignty was restored in 1934 and remains in place today. ${ }^{76}$ How might one rationalize this more complex context? To return to Holmes's aphoristic analysis: Which is today's "accidental relic," the presence of nonmembers on reservations long after the abandonment of allotment. or the continuation of tribal sovereignty itself? Can federal judges adjudicate disputes in this controversial environment by following the "felt necessities of the time" without falling victim to "shared prejudices"?

It is probably not surprising that, in this more muddled context, courts have sometimes limited tribal authority over nonmembers. Two basic strategies have emerged. As Solem indicates, one method is to reexamine the location of reservation boundaries in order to free largely non-Indian areas from tribal control. Because neither Congress's embrace of the allotment policy nor its subsequent abandonment of it explicitly dealt with the question of reservation boundaries, Congress created a conundrum of treaty and statutory interpretation concerning the limits of reservations. Part III examines how, despite the canons of interpretation, the contemporary Supreme Court has sometimes interpreted century-old allotment statutes as diminishing reservation size. A second avenue for truncating tribal authority is to conclude, as Bourland did, that nonmembers are immune from tribal power even if found on a reservation. As Part IV explains, the disruptive impact of allotment has led to a contemporary reevaluation of which tribal powers are inconsistent with current domestic dependent status.

75. See Act of June 2, 1924, ch. 233, 43 Stat. 253.

76. For a brief overview, see Frickey, supra note 68 , at $1138 \&$ n.7. $1178-79 \&$ nn.225-26. President Clinton has aggressively reaffirmed the principle of tribal sovereignty. See Consultation and Coordination with Indian Tribal Governments, Exec. Order No. 13,084, 63 Fed. Reg. 27,655 (1998); Government-to-Government Relations with Native American Tribal Governments: Memorandum for the Heads of Executive Departments and Agencies, 59 Fed. Reg. 22.951 (1994). 


\section{DIVESTING TRIBAL TERRITORIAL SOVEREIGNTY BY REDUCING THE TERRITORY}

The allotment policy produced the enduring presence of non-Indians in Indian country, the transfer of significant portions of formerly Indian land to non-Indians, and substantial conflict over reservation boundaries. Justice Marshall's opinion for the unanimous Court in Solem is the most honest attempt to understand what allotment was and what it produced. Unfortunately, by the time Solem was decided the Court had embraced an approach that is incompatible with candor.

In Solem, Justice Marshall began by noting that the allotment statutes "seldom detail whether opened lands retained reservation status or were divested of all Indian interests." $n$ This distinction was unimportant at the time of enactment because Congress understood reservation status and tribal ownership to be synonymous and assumed that allotment would rapidly assimilate Indians into the broader society, causing "the reservation system [to] cease to exist." 78 "Given this expectation, Congress naturally failed to be meticulous in clarifying whether a particular piece of legislation formally sliced a certain parcel of land off one reservation." 79 Years later, after the allotment process was abandoned, Congress "uncouple[d] reservation status from Indian ownership" ${ }^{80}$ by defining "Indian country" to encompass all reservation lands, including that owned by non-Indians. ${ }^{81}$

Note precisely what Marshall posited: The statutes did not address reservation boundaries, and Congress did not deliberate about them. A straightforward application of the principle that statutes diminish Indian interests only when Congress has spoken clearly ${ }^{82}$ would, therefore, compel the conclusion that reservation boundaries remained intact in every instance fairly covered by Marshall's historical generalizations-which would presumably include every allotment statute. The only way out of this conclusion would seem to be to abandon the clear-statement canon and privilege some other source of legal determinacy. One potential technique would be to fall back upon the original congressional purposes associated with allotment, which of course was designed to destroy the reservation system. Interpreting the statutes in light of their original purposes would produce the converse conclusion that the reservation was diminished in every instance fairly covered by Marshall's generalizations-again, presumably in every case. Yet in Solem Marshall squarely rejected any

77. Solem v. Bartlett, 465 U.S. 463,468 (1984).

78. Id.

79. 1 ld.

80. $I d$.

81. Id. (citing 18 U.S.C. § 1151 (1994)); see also supra note 12 (quoting this statute).

82. See supra text accompanying note 57 . 
categorical resolution of these controversies by such purposive interpretation. ${ }^{83}$ Instead, consistent with the canonical method, he wrote that Congress must "clearly evince an 'intent to change boundaries' before diminishment will be found." ${ }^{84}$

This resort to established principle did not, however, produce the categorical resolution of these controversies that logic would require. The four cases on diminishment prior to Solem had reached disparate outcomes - the first two had found no diminishment; ${ }^{85}$ the other two, with Marshall in dissent, had found diminishment. ${ }^{86}$ In attempting to follow these precedents in Solem, Marshall undermined the conceptual clarity and outcome-producing quality of the canonical approach by supplementing it in three ways.

The first was to categorize the cases based on the precise statutory text at issue in them. Marshall read the precedents as establishing what might uncharitably be called a "magic language" approach to statutory interpretation. In a case finding a diminishment, the statute stated that the tribe agreed to "cede, sell, relinquish, and convey to the United States all [the Indians'] claim, right, title and interest" ${ }^{87}$ in unallotted lands in return for a specified sum. In contrast, in a precedent finding no diminishment, the statute directed the Secretary of the Interior "to sell or dispose of" unallotted lands, with the tribe receiving whatever proceeds were generated. ${ }^{88}$ Thus,

[e]xplicit reference to cession or other language evidencing the present and total surrender of all tribal interests strongly suggests that Congress meant to divest from the reservation all unallotted opened lands.... When such language of cession is buttressed by an unconditional commitment from Congress to compensate the Indian tribe for its opened land, there is an almost insurmountable

83. According to Marshall:

Although the Congresses that passed the surplus land Acts anticipated the imminent demise of the reservation and, in fact, passed the Acts partially to facilitate the process, we have never been willing to extrapolate from this expectation a specific congressional purpose of diminishing reservations with the passage of every surplus land Act.

Solem, 465 U.S. at $468-69$.

84. Id. at 470 (quoting Rosebud Sioux Tribe v. Kneip, 430 U.S. 584, 615 (1977)).

85. See Mattz v. Amett, 412 U.S. 481 (1973); Seymour v. Superintendent, 368 U.S. 351 (1962).

86. See Kneip, 430 U.S. 584; DeCoteau v. District County Court, 420 U.S. 425 (1975). Marshall wrote a dissent in Kneip, see 430 U.S. at 615, and joined Justice Douglas's dissent in DeCoteau, see 420 U.S. at 460.

87. See Solem, 465 U.S. at 469 n.10 (discussing DeCoteau, 420 U.S. at $439-40$ n.22, 445).

88. See id. (discussing Seymour, 368 U.S. 351 ). 
presumption that Congress meant for the tribe's reservation to be diminished. ${ }^{89}$

It belabors the obvious to note that these conclusions cannot coincide with the approach embraced by Marshall earlier in Solem. Focusing on statutory text was disingenuous when he had already concluded that only clear congressional intent could diminish Indian interests and that Congress had not been meticulous in clarifying whether allotment affected reservation borders. In any event, surely even a modest application of the canon would treat "cede, sell, relinquish, and convey" for a specified amount as ambiguous concerning whether the tribe had simply agreed to convey land title or had also taken the extraordinary act of ceding away whatever sovereignty it had then or might be recognized as having in the future.

The second step Marshall took was to posit that, under the precedents, circumstances surrounding an enactment may support a finding of diminishment. ${ }^{90}$ To be sure, such circumstances did serve as the basis for the Court's inference of diminishment in a case where the statute arguatly lacked magic language. ${ }^{91}$ Inferences of diminishment, however, should not count under the canonical approach. Relying upon them is perilously close to adopting the purposive approach to interpreting allotment statutes that would likely result in diminishment in all cases and that Marshall had already rejected earlier in Solem.

Finally, Marshall read the cases as establishing that, "[t]o a lesser extent, ... events that occurred after the passage" of the statute should be examined "to decipher Congress['s] intentions." 92 The conceptual problem with this approach, of course, is that postenactment developments reveal nothing about original congressional intent, much less intent sufficiently clear to satisfy the canon. ${ }^{93}$ The relevant postenactment factors turn out to

89. Id at $470-71$.

90. See id at 471 (mentioning the negotiations history, legislative history, federal and state treatment of the area immediately following enactment, and demographics of the area soon after allotment).

91. See id. at 469 n.10, 471 (explaining Kneip, 430 U.S. 584). The first in a series of statutes concerning this reservation did contain "magic language," however. See Kneip. 430 U.S. at 591 n.8; cf. Hagen v. Utah, 510 U.S. 399, 427 (1994) (Blackmun. J., dissenting) (treating the Kneip case as involving magic language).

92. Solem, 465 U.S. at 471.

93. Marshall wrote that "we look to the subsequent demographic history of opened lands as one additional clue as to what Congress expected would happen once land on a particular reservation was opened to non-Indian settlers." Id. at 471-72. If only Congress could be so prescient in other areas in which it legislates! Marshall further explained: "Resort to subsequent demographic history is, of course, an unorthodox and potentially unreliable method of statutory interpretation. However, in the area of surplus land Acts, where various factors kept Congress from focusing on the diminishment issue, ... the technique is a necessary expedient." Id. at 472 n.13. Under the canonical approach supposedly followed in Solem, however, no expedient is needed, and the technique is irrelevant. 
be the demographics of the disputed area and its jurisdictional treatment by the federal and state governments-whether the area had "lost its Indian character" 94 and had fallen out of tribal control. Marshall noted "the obvious practical advantages of acquiescing to de facto diminishment" ${ }^{95}$ Such areas are more easily administered by state and local authorities. ${ }^{96}$ Conversely, "a largely Indian opened area" outside a reservation results in "imbalanced checkerboard jurisdiction" ${ }^{97}$ because the Indian trust lands remain under federal and tribal authority while neighboring non-Indian lands are under state and local control. ${ }^{98}$

Postenactment developments, the least legally probative considerations mentioned in Solem, turn out to be the most outcome-determinative factors in the cases. ${ }^{99}$ The two cases before Solem that found diminishment involved heavily non-Indian areas; ${ }^{100}$ the other two cases, in which no diminishment was found, contained no suggestion that the reservation had lost its Indian character. ${ }^{101}$ Despite all of its agonizing efforts to render the inquiry a matter of legal principle, Solem is consistent with this analysis. It stressed that allotment "was a failure" 102 on Cheyenne River, that the "population of the disputed area is now evenly divided between Indian and non-Indian residents," 103 that "roughly two-thirds of the Tribe's enrolled members live in the opened area," 104 and that the "seat of tribal government is now located in a town in the opened area, where most important tribal activities take place." 105 Accordingly, "it is impossible to say that the opened areas of the [reservation] have lost their Indian character." 106

Solem is a puzzle when viewed on its own terms, as a statutory interpretation case involving a canon focusing on congressional intent. When it and the prior diminishment cases are assessed through a wider lens, however, it seems that the Supreme Court resolved each of them not by

\section{Id. at 471 .}

95. Id.

96. See id. at 471 n. 12.

97. Id.

98. "Indian country" includes all Indian trust allotments of land and all dependent Indian communities, as well as all land within a reservation. See 18 U.S.C. \& 1151 (1994), quoted supra note 12.

99. See, for example, Laurence, Judicial Reluctance, supra note 20, at 789-90; and James M. Grijalva et al., Diminishment of Indian Reservations: Legislative or Judicial Fiat?, 71 N.D. L. REV. 415 (1995), especially the comments of Frank Pommersheim in Grijalva et al., supra. at 422. 100. See Rosebud Sioux Tribe v. Kneip, 430 U.S. 584, 604-05 (1977) (noting that the state had long exercised jurisdiction over the disputed area, which was over $90 \%$ non-Indian): DeCoteau v. District County Court, 420 U.S. 425, 428 (1975) (stating that the disputed area contained "about 3,000 tribal members and 30,000 non-Indians").

101. See Mattz v. Arnett, 412 U.S. 481, 505 (1973); Seymour v. Superintendent, 368 U.S. 351,356 (1962).

102. Solem, 465 U.S. at 480.

103. Id.

104. Id.

105. Id.

106. $I d$. 
statutory interpretation, but by practical, contextual judgments concerning whether, because of postenactment developments, the disputed area had lost its "Indian character." The judicial focus was on the current and the concrete, not on the historical or the textual, the supposed importance of "magic language" notwithstanding. In short, the Court implicitly embraced a common-law-like approach that displaced statutory interpretation.

A decade after Solem was decided, Hagen v. Utah ${ }^{107}$ returned the Court to the now-familiar pattern of reservation allotment, non-Indian settlement, and decades of jurisdictional confusion. The history of the statute in question seemed to fit Justice Marshall's conclusion in Solem that Congress did not consider reservation boundaries in opening the reservation. Nor did the statute contain the "magic language" of cession of tribal interests recognized in earlier cases. Accordingly, as the Solicitor General argued as amicus curiae in support of the tribal position, the canonical approach compelled the conclusion that the reservation had survived allotment intact. ${ }^{108}$ The opened area was eighty-five percent non-Indian, however. ${ }^{109}$ Predictably, the press of current context overwhelmed the canonical construct.

Justice O'Connor's majority opinion finding diminishment is susceptible to both legalistic and realistic readings. Legalistically, her approach was based on two premises. First, she rejected the Solicitor General's canonical argument because the precedents "require[] us to examine all the circumstances surrounding the opening of a reservation." 110 Second-and inconsistently-she created a new category of magic language that trumped all other potential sources of statutory meaning. She held that the statutory text providing that "all the unallotted lands within said reservation shall be restored to the public domain" amounted to a congressional directive that the lands had lost their Indian reservation status. ${ }^{111}$ Realistically, her opinion stressed current factors: the overwhelming non-Indian demographics and the longstanding state assertion of jurisdiction over the opened lands. ${ }^{112}$ These considerations "demonstrate[ a practical acknowledgment that the Reservation was diminished; a contrary conclusion would seriously disrupt the justifiable expectations of the people living in the area." 113

107. 510 U.S. 399 (1994).

108. See id. at 411-12.

109. See id. at 421.

110. Id. at 412 .

111. Id. As Justice Blackmun argued in dissent, however, the term "public domain" is ambiguous and could easily be understood as simply making the lands in question available for non-Indian purchase and settlement, not removing them from the reservation to boot. See id. at 427-30 (Blackmun, J., dissenting).

112. See id. at 421 .

113. Id. (emphasis added). 
Hagen stands in stark contrast to Solem, which rejected reliance upon general congressional assimilative purposes unadorned by explicit congressional intent. The most coherent understanding of Hagen is that, even in the absence of clear congressional intent, such a purpose does control if through the passage of time it has achieved fruition in current demographics, patterns of governance, and "justifiable expectations" of non-Indians. The alternative, and more legalistic, understanding of Hagen, which turns on an expandable category of magic language, is neither well justified in Hagen nor easy to square with the most recent diminishment case, which utterly deflates the importance of the text of positive law.

South Dakota v. Yankton Sioux Tribe ${ }^{114}$ involved facts that seem more like a law school examination question than a Supreme Court case. The surplus lands agreement contained the magic language supposedly indicating diminishment. Yet it also contained a seemingly bulletproof savings clause providing that "[n]othing in this agreement shall be construed to abrogate" the preexisting Indian treaty establishing the reservation. ${ }^{115}$ Of course, if the agreement diminished the reservation, it unquestionably abrogated the provisions of the earlier treaty. Thus, the Court seemed to have written itself into a corner in Yankton, for its "magic language" approach to diminishment ran squarely into the literal language of the savings clause. Presumably, even under a watered-down canonical approach, such a square textual conflict should be resolved in favor of the tribal position. Yet the demographics of the disputed area were, again, heavily non-Indian, ${ }^{116}$ and the state had exercised jurisdiction since the time of allotment. ${ }^{117}$ Should the Court simply abandon legalisms and capitulate to its perception of the practical solution-deferring to the status quo of non-Indian regional character, "reasonable" non-Indian expectations, and state jurisdiction?

As in Hagen, the impression of a non-Indian status quo made the outcome against the tribe in Yankton predictable, even if the legalistic rationale was difficult to foresee. ${ }^{118}$ Indeed, with Justice Blackmun now retired, no Justice even bothered to dissent from Justice O'Connor's opinion in Yankton finding a diminishment.

Legalistically, as one would expect, Justice O'Connor relied upon the presence of the magic language. The critical move in her opinion was then to conclude that a "literal construction of the saving clause" would

114. 118 S. Ct. 789 (1998). For a strong critique of the decision, see Judith V. Royster, of Surplus Lands and Landfills: The Case of the Yankton Sioux, 43 S.D. L. REV. 283 (1998).

115. Yankton, $118 \mathrm{~S}$. Ct. at 795 n.1.

116. See id. at 804 .

117. See id.

118. In answering a question posed in my fall 1996 examination on federal Indian law that was based on this case, a number of my students predicted that the tribe would lose because of "bad facts" but had difficulty articulating a legal theory to support that outcome. 
"impugn the entire sale." "In short, she reasoned that the magic language created such a strong presumption of diminishment that the savings clause could not be taken at face value. She did not consider the alternative explanation: that the savings clause showed the folly of relying upon magic language in the first place. Invoking the canon that courts should avoid absurd results, she then narrowly interpreted the savings clause as concerning only the continuation of the payment of annuities required by the earlier treaty, and not the integrity of the treaty-defined reservation borders. ${ }^{120}$ In response to the canonical argument that, at a minimum, the agreement was ambiguous and therefore should be interpreted to favor the tribe, she simply dogmatically stuck to the position that, under the relevant precedents, the presence of the magic language "plainly indicates diminishment," and that the canonical method is not "a license to disregard clear expressions of tribal and congressional intent." 121

Even aside from the canon, however, formidable principles of interpretation stood in the way of privileging the magic language and essentially writing the savings clause out of the agreement. The Court today approaches statutory interpretation with an eye toward textual integrity ${ }^{122}$ a "holistic endeavor" 123 that seeks to avoid the conclusion that any portion of text is redundant or superfluous or should be read out of a statute. Tellingly, the savings clause at issue in Yankton was apparently the strongest version of any such clause found in an Indian treaty or agreement. ${ }^{124}$ The contrast between it and the weaker clauses in other treaties and agreements should have led the Court to give it its plain meaning. The Court has engaged in this sort of "whole code" harmonization approach in recent years. ${ }^{125}$ That it failed to undertake any effort in this regard demonstrates the degree to which the text of positive law and even the techniques of statutory interpretation lack explanatory value in these cases, the invocation of "magic language" and canonical method notwithstanding.

Realistically, the savings clause did not stand much of a chance of surviving state assumption of jurisdiction and non-Indian demographic dominance. That the Court felt comfortable deferring to its perception of the status quo was indicated by its statement that "the area remains

119. Yarkton, 118 S. Ct. at 799 (quoting State v. Greger, 559 N.W.2d 854. 863 (S.D. 1997)).

120. See id. at 799-800.

121. Id at 800-01 (quoting DeCoteau v. District County Court. 420 U.S. 425,447 (1975)).

122. See generally William N. Eskridge. Jr., The New Texfualism, 37 UCLA L. REv. 621 (1990) (documenting the rise of the "new textualism," under which statutory interpretation is determined by assessing the ordinary meaning and coherence of text).

123. United Sav. Ass'n v. Timbers of Inwood Forest Assocs., 484 U.S. 365, 371 (1988).

124. See Brief Amici Curiae of Standing Rock Sioux Tribe and Assiniboine and Sioux Tribes of the Fort Peck Reservation in Support of Respondent Yankion Sioux Tribe at 4-9, South Dakota v. Yankton Sioux Tribe, 118 S. Ct. 789 (1998) (No. 96-1581).

125. See, e.g., West Virginia Univ. Hosps. v. Casey, 499 U.S. 83. 100-01 (1991). 
'predominantly populated by non-Indians with only a few surviving pockets of Indian allotments,' and those demographics signify a diminished reservation." 126

Taken as a whole, the judicial method in the diminishment cases might appear to be essentially lawless. To place a legalistic gloss on what amounted to mere deference to the perceived status quo, the Court first gave undue weight to language of cession and payment of a sum certain. Next, in Solem, which involved an area that, to non-Indian eyes, had not lost its Indian character, the Court unduly contrasted the legal impact of the "magic language" with words_- "sell and dispose of"-meaning about the same thing. Throughout these cases, the Court maintained that it had not abandoned the canonical method, in which only clear congressional intent could result in diminishment. Yet, in Yankton, the most recent case, the canonical method ended up completely impotent, lacking even sufficient force to tip the scales in favor of the tribe when a square textual conflict arose between recognized "magic language" and an impenetrable savings clause. In totality, the cases suggest that, to adapt an old joke about Congress, no Indian reservation is safe while the Supreme Court is in session.

Perhaps it is unfair, however, to castigate the Court for these decisions. After all, it was Congress that established the policy of allotment in order to destroy reservations. Congress then abandoned the policy, but did nothing to undo the damage already wrought by it. The Court is left in the unhappy situation of having to clean up the mess, a century later, on a case-by-case basis. The Court has, arguably, tried to reach practical resolutions of each dispute, deferring to the demographics and settled jurisdictional patterns that are present.

Indeed, what the Court has done might be defensible not just practically, but jurisprudentially as well. In all these cases, no explicit statutory text or clear legislative intent governs the diminishment question, but a general congressional purpose is embedded in every allotment statute-to destroy the reservation system and assimilate Indians into the larger society. Under the common practices of statutory interpretation, statutory purpose is the next best source of meaning where statutory text and legislative intent are inconclusive. ${ }^{127}$ In light of its "traditional solicitude for the Indian tribes," however, as Justice Marshall explained in

126. Yankton, 118 S. Ct. at 804 (quoting Solem v. Bartlett, 465 U.S. 463, 471 n.12 (1984)) (emphasis added).

127. See William N. Eskridge, Jr. \& Philip P. Frickey, Statutory Interpretation as Practical Reasoning, 42 STAN. L. REV. 321, 345-62 (1990). Under the model of statutory interpretation proposed in Henry M. HART, JR. \& Albert M. SACKS, THE LEGal Process: Basic Problems IN THE MAKING AND APPLICATION OF LAW 1374-80 (William N. Eskridge, Jr. \& Philip P. Frickey eds., 1994), the judicial attribution of purpose is the primary method of ascertaining statutory meaning. 
Solem, ${ }^{128}$ the Court has not implemented this general congressional purpose in every case. Where the regional character and settled jurisdictional patterns provide practical support for treating the disputed area as Indian country, the Court has done so. These are instances of dynamic statutory interpretation, in which general legislative purpose is deflated in light of subsequent circumstances unforeseen by the legislature. ${ }^{129}$ But where current circumstances seem consistent with original general congressional purpose, the Court has deferred to legislative supremacy by reaching the assimilative result of diminishment.

This account is the best that I can muster in support of the diminishment cases. Even under it, the Court scores poorly on any evaluation of its candor. If I have portrayed accurately what the Court has done, why it has done it, and how what it has done might be supportable jurisprudentially, the Court should forthrightly abandon the fiction that the cases are rooted in explicit congressional intent. It should admit that the basic inquiry is whether century-old general congressional purpose has reached fruition in the current context.

In the final analysis, however, having done the best I can to put a good jurisprudential face on the Court's work, I still find it exceptionally wanting. It ignores at least two important factors.

The first problem with the Court's work is that Congress has repudiated the allotment policy. The Court has never explained why an obsolete general congressional purpose lacking specific statutory text or clear legislative intent purporting to bind future generations deserves respect today. Moreover, by refusing to admit that it is implementing a general (and repudiated) congressional purpose rather than explicit congressional intent, the Court has sought to shift the blame for the erosion of tribal authority to a century-old Congress rather than where it belongs-the current Court. ${ }^{130}$

Presumably, what is motivating the Court is not some jurisprudential notion that it must implement obsolete statutory purpose, come what may. Instead, the animating factor is surely the desire to protect what the Court in Hagen called the "justifiable expectations" ${ }^{131}$ of the non-Indians now

128. Solem v. Bartleth, 465 U.S. 463,472 (1984).

129. See generally WILlIAM N. ESKRIDGE. JR., DYNAMIC STATUTORY INTERPRETATION (1994).

130. The effort to pass the buck is illustrated by Yankton:

The allotment era has long since ended, and its guiding philosophy has been repudiated. Tribal communities struggled but endured. preserved their cultural roots, and remained. for the most part, near their historic lands. But despite the present-day understanding of a "government-to-govemment relationship between the United States and each Indian tribe," see, e.g., 25 U.S.C. \$ 3601, we must give effect to Congress's intent in passing the $1894 \mathrm{Act}$. Here, as in DeCoreau, we believe that Congress spoke clearly, and although "[s]ome might wish [it] had spoken differently... we cannot remake history."

118 S. Ct. at 805 (quoting DeCoteau v. District County Coun, 420 U.S. 425,449 (1975)).

131. Hagen v. Utah, 510 U.S. 399, 421 (1994). 
residing on reservations. In addition, presumably the Court believes that it should try to allocate jurisdiction so that largely non-Indian areas are subject to state, rather than tribal and federal, control. These are weighty policy considerations, and it will not do for those who sympathize with tribes to brush them off. The real culprit is not the non-Indians, but Congress, which established the policy creating the incentives for nonIndian settlement and then abandoned it, leaving the non-Indians high and dry while doing little to undo the damage caused to tribal interests. There is plenty of pain to go around in the historical and contemporary lessons of allotment.

At a minimum, however, the Court has never sought to justify that it is empowered to balance such hardships in the first place, much less to identify what counts as hardship and what importance should be given to each hardship. The Court seems to see these matters as one-sided, involving unfairly put-upon non-Indians who suffer from potential regulation by an archaic sovereign that continues to exist merely as one of Holmes's accidents of history. The baseline assumption seems to be that state jurisdiction over Indian and non-Indian alike is customary, fair, and efficient, while tribal responsibility concerning non-Indians is bizarre, unfair, and inefficiently overlapping with state authority. Why is non-Indian autonomy privileged and tribal authority displaced-in the context of a repudiated assimilationist policy and a current policy of promoting tribal sovereignty? What is it about assimilation and state jurisdiction that strikes the Court as coherent, and tribal autonomy and geographical sovereignty as incoherent? Does the judicial instinct grow out of melting-pot notions of "We the People," ignoring that "We" did not create our constitutional democracy on uninhabited land, but rather placed our system on top of, and ultimately displaced, preexisting "Peoples"? Under a broader perspective, what is natural, neutral, and coherent may become quite confused.

The second problem with what the Court has done in the diminishment cases is that, while claiming the contrary, it has veered away from the canonical method of resolving federal Indian law disputes, a technique rooted in over a century and a half of precedent. To be sure, the Court has the authority to do this, but at a minimum it should discuss the problem forthrightly. Why does the presence of a sufficient number of non-Indians undermine the canonical method? Of course, that method was created in the absence of significant non-Indian interests, and it may be appropriate to reconsider it in light of the more complicated contemporary circumstances. But a reading of these cases suggests not a careful current reevaluation, but a casual, unreflective concession to non-Indian instincts-Holmes's " felt necessities of the time," which may contain the seeds of "prejudices which judges share with their fellow [citizens]." In any event, regardless of 
whether the Court's instincts merit the epithet "prejudice," it seems clear with which of their fellow citizens the Justices share more empathy.

In the last analysis, then, it is not unfair to hold the Court responsible in these cases. It is the Court, after all, that is exercising the critical choice of preferring general, obsolete congressional purpose to the canonical method. No positive law-nothing in the Constitution or federal statute-compels the Court to embrace one approach or the other. In our written corpus of law, it is the Court's own opinions that provide the most relevant text to evaluate in making this choice. And the most longstanding, and most thoughtful, of them support a canonical approach. ${ }^{132}$ Of course, whichever way the Court goes, Congress has the authority to alter the outcome. But this allocation of first-line judicial case-by-case responsibility and secondlevel discretionary legislative revisionary capacity just reaffirms the common-law feel of this domain.

In conclusion, the Court has commissioned itself in these cases to rework jurisdictional lines in federal Indian law using a methodology that Holmes would have recognized as case-by-case common-lawmaking rooted in "felt necessities." Unfortunately, the Court has not acknowledged the pretense of its nod to statutory interpretation and the reality of its embrace of common-law methodology to reach these results, much less defended its movement away from the canonical scheme established in longstanding precedent. Moreover, only in a circuitous way has the Court identified the postenactment factors that seem to be driving these outcomes. Solem embarrassingly admitted that these factors have little to do with statutory interpretation, but no opinion carefully considers how they combine in a defensible and predictable manner in the Court's broader common-law methodology. One is left with the suspicion that a number of unarticulated (and perhaps even unrecognized) values are at work. The elegant formulation of Indian law principles has been displaced, in a more culturally complicated context, by an ad hoc balancing test. Whether an area is "Indian country" is no longer as much a question of law as it is one of fact. Much of the impetus for this shift seems to be a sense that nonmembers are "really" in a region meriting the term "Indian country" only when the area has retained its "Indian character" - a culturally loaded concept of dubious determinacy in the hands of non-Indian judges.

As the next Part indicates, this same problem has arisen when the Court has encountered the authority of tribes to regulate nonmembers even within acknowledged reservation boundaries. Here, too, the traditional principles have been displaced on a case-by-case basis by unarticulated values and felt necessities.

132. See Frickey, supra note 22, at $385-417$ (describing the methodology of the Marshall Court in federal Indian law cases). 


\section{DIVESTING TRIBAL TERRITORIAL SOVEREIGNTY BY REDUCING THE SOVEREIGNTY}

In its first two encounters with assertions of tribal power over nonmembers in Indian country, the Supreme Court dismissed the objections of nonmembers and affirmed tribal authority. These cases, which involved tribal-court jurisdiction over civil disputes with non-Indian plaintiffs and tribal capacity to exercise power authorized by Congress, are the subjects of Sections A and B of this Part. The implication of these precedents that tribes possess full territorial sovereignty did not survive later cases involving more difficult questions of tribal authority over nonmembers, however. Unfortunately, the Court has failed to articulate a principled and coherent understanding of this series of decisions. Accordingly, the cases are best categorized by subject matter rather than by rationale. In the absence of congressional authorization of, or nonmember consent to, tribal action, the Court has forbidden tribal criminal jurisdiction over nonmembers, as Section $C$ documents, and precluded civil regulation of nonmembers unless their conduct threatens core tribal interests, as Section $\mathrm{D}$ demonstrates. These cases might be explainable by a judicial presumption that tribal regulatory authority over nonmembers is curtailed when they may not be excluded from the reservation, but this rationale cannot be squared with cases upholding tribal power to tax them, as Section E demonstrates. Finally, as Section F explains, in yet another series of cases concerning tribal-court jurisdiction in civil cases with nonmember defendants, the Court initially took a sympathetic approach to tribal authority, only to undercut it in more recent precedent.

What follows is an elaborate account of six categories of cases. When the decisions are assessed on their own terms, the search for coherence within and across these categories shall prove elusive. Later, in Part V, I suggest that a different framework of analysis may prove more successful in explaining the underlying pattern of precedent.

\section{A. The Foundational Precedent: Williams v. Lee and Tribal-Court Jurisdiction in Civil Cases Brought by Nonmembers Against Members}

In Williams $v$. Lee, ${ }^{133}$ a non-Indian operating a store on the Navajo Reservation brought an action in Arizona state court against a Navajo family that had allegedly failed to pay for goods sold on credit. The state courts entertained the case because no federal law preempted their jurisdiction. ${ }^{134}$ On review, the Supreme Court faced its first decision in " the

133. 358 U.S. 217 (1959).

134. See Williams v. Lee, 319 P.2d 998 (Ariz. 1958). 
modern era of federal Indian law," ${ }^{135}$ at least in part because this was the Court's first encounter with tribal sovereignty in a contemporary context in which non-Indians were involved.

Because no treaty or statute controlled, the Court had significant discretion in resolving the dispute. Should it adhere to traditional constructs, rooted in Marshall Court decisions adopted when Indian reservations consisted simply of Indian land inhabited by Indians, to invalidate state jurisdiction and leave the matter to the tribal court? Or should changed circumstances-the granting of United States citizenship to Indians; the complicated post-allotment demographic context; a few Allotment-era and later precedents undermining the notion that the federaltribal relationship left no role for states in Indian country ${ }^{136}$-lead the Court to abandon tribal sovereignty and allow state courts to apply state law to resolve the dispute?

Writing for a unanimous Court, Justice Black blended the decisions of the Marshall Court and the institutional sensitivity of the traditional constructs with the path of subsequent federal Indian law. Black wrote that tribes, which originally were "separate nations," 137 had been induced " $[t]$ hrough conquest and treaties ... to give up complete independence and the right to go to war in exchange for federal protection, aid, and grants of land." 138 Nonetheless, he continued, Worcester had held that tribes remained independent of state law on the reservation. Black described Worcester as one of Chief Justice Marshall's "most courageous and eloquent opinions." 139 "Despite bitter criticism and the defiance of Georgia which refused to obey this Court's mandate," Black continued, "the broad principles of that decision came to be accepted as law." 1+0

But what of later precedents allowing state law to seep into Indian country? For the Court in Williams, they did not undermine the general rule of Worcester, which could be dislodged only by agreement or statute, not by judicial decision. Thus, the Court concluded: "Essentially, absent governing Acts of Congress, the question has always been whether the state action infringed on the right of reservation Indians to make their own laws and be ruled by them." ${ }^{141}$ State-court jurisdiction "would undermine the

135. Charles F. Wilkinson, AMERICAN INDIANS, TIME, AND THE LAW 1 (1987).

136. For the Court's own brief overview of the precedents, see Williams, 358 U.S. at 219-20.

137. Id at 218.

138. Id.

139. Id at 219.

140. Id. Guido Calabresi, who clerked for Justice Black at the time, once mentioned to me that Justice Frankfurter's note to Black joining the opinion in Williams said that he was pleased to concur in this indirect reaffirmation of Brown v. Board of Education. Willioms was decided only a year after Cooper v. Aaron, 358 U.S. 1 (1958), involving the resistance of state officials to school integration. See Robert A. Burt, Constitutional Law and the Teaching of the Parables, 93 YALE L.J. 455, 482 n.89 (1984) (reporting a similar conversation with Calabresi).

141. Williams, 358 U.S. at 220. 
authority of the tribal courts over Reservation affairs and hence would infringe on the right of the Indians to govern themselves," ${ }^{142}$ presumably because self-government includes having one's own courts apply one's own rules of decision to disputes arising within one's own territory.

But what of the more complicated demographic context? The Court in Williams forced the non-Indian plaintiff to bring the case in tribal court ${ }^{143}$ and assumed that it would be resolved under tribal law, even though he had no vote in tribal elections and, presumably, only tribal members could serve on juries. Any claim of unfairness, Justice Black wrote, foundered on the notion of territorial sovereignty and its corollary, implied consent to governmental authority. Consistent with the traditional principles, Black considered Congress, not the Court, the appropriate institution for altering federal Indian law in light of changed circumstances. ${ }^{144}$

On its surface, Williams was simply about state-court jurisdiction. The Court's rationale for barring that jurisdiction, however, reaffirmed the concept of tribal sovereignty in the modern, more demographically complicated era. Perhaps one reason the Court did so was that, from the tribal point of view, Williams was a wonderful test case. It arose on the Navajo Reservation, which was never generally subjected to allotment and is the paradigm of a reservation retaining its Indian character in the modern era. ${ }^{145}$ Moreover, as Justice Black noted, the Navajo had tribal courts in place to resolve "suits by outsiders against Indian defendants." 146 Finally, unlike a non-Indian reservation landowner, the non-Indian in Williams could not claim any arguably reasonable expectations concerning immunity from tribal regulation: He was on the reservation only by virtue of a federal license to be an "Indian trader." ${ }^{47}$

Over a decade and a half passed before the Supreme Court again encountered the assertion of tribal authority over a non-Indian found on a reservation. When it returned to the subject, it considered a case that, in

142. Id. at 223.

143. The case involved no federal question or diverse citizenship supporting federal jurisdiction.

144. Black wrote:

It is immaterial that respondent is not an Indian. He was on the Reservation and the transaction with an Indian took place there.... The cases in this Court have consistently guarded the authority of Indian governments over their reservations. Congress recognized this authority in the Navajos in the Treaty of 1868 . and has done so ever since. If this power is to be taken away from them, it is for Congress to do it.

Williams, 358 U.S. at 223 (citations omitted). Earlier Black had noted that Congress had given Arizona the ability to obtain jurisdiction for its courts over civil cases arising on Indian reservations and that the state had never exercised this option. See id. at 222-23 (citing Public Law 280 , Act of Aug. 15, 1953, ch. 505, \$§ 6-7,67 Stat. 590).

145. See supra text accompanying note 73 .

146. Williams, 358 U.S. at 222 . At the time, such tribal courts were relatively scarce. See WILKINSON, supra note 135 , at 2.

147. See Williams, 358 U.S. at 217. 
some sense, might have been considerably easier than Williams for ruling in favor of tribal sovereignty.

\section{B. Congressional Authorization of Tribal Power}

United States v. Mazurie ${ }^{148}$ directly posed the complaint of non-Indians that they should not be subject to tribal authority. Unlike Williams, where tribal capacity to establish law on the reservation came into the equation indirectly, as a matter of judicial civil jurisdiction, Mazurie involved nonIndians subjected to federal criminal prosecution for failing to adhere to tribal law.

Mazurie concerned a federal criminal statute requiring all vendors of alcohol in Indian country to comply with both state and tribal law. ${ }^{149}$ NonIndians who operated a bar on reservation land that they held in fee failed to comply with tribal liquor licensing laws and were federally prosecuted. The Court of Appeals for the Tenth Circuit threw out the case on the ground that the statute exceeded the power of Congress over Indian affairs. ${ }^{150}$ Embracing the popular sentiment of non-Indians in Indian country, ${ }^{151}$ the court of appeals viewed the tribe as simply a membership organization of American citizens that could have no authority over "other citizens who do not belong, and who cannot participate in any way in the [tribal] organization." 152 The court concluded that "Congress cannot delegate its authority to a private, voluntary organization, which is obviously not a governmental agency, to regulate a business on privately owned lands, no matter where located." 153

In reversing, the Supreme Court did not reach the question whether the tribe's inherent sovereignty was expansive enough to allow it to regulate non-Indian alcohol vendors in the absence of authorization by Congress. Instead, the Court took a narrower route, concluding that the statute constituted a lawful congressional delegation of regulatory power to the tribe. Writing for a unanimous Court, Justice Rehnquist conceptualized tribes not as "private, voluntary organizations," 1st but instead as "unique aggregations possessing attributes of sovereignty over both their members

148. 419 U.S. 544 (1975).

149. Federal criminal law outlaws the introduction of alcohol into Indian country, see id. at 545 (citing 18 U.S.C. $\$ 1154$ ), unless the transaction is in conformity with state law *and with an ordinance duly adopted by the tribe having jurisdiction over such area of Indian country, certified by the Secretary of the Interior, and published in the Federal Register," id. at 547 n.4 (quoting 18 U.S.C. \$ 1161).

150. See United States v. Mazurie, 487 F.2d 14 (10th Cir. 1973).

151. See supra note 6 and accompanying text.

152. Mazurie, 487 F.2d at 19.

153. Id

154. United States v. Mazurie, 419 U.S. 544, 557 (1975). 
and their territory." ${ }^{155}$ Because tribes were governmental entities possessing at least some "independent authority over the subject matter," ${ }^{156}$ Congress could lawfully "vest in tribal councils this portion of its own authority "to regulate Commerce ... with the Indian tribes." 157

But what of the non-Indians' complaints of unfairness? The Court offered three rejoinders. First, it quoted language from Williams recognizing tribal territorial sovereignty. ${ }^{158}$ Second, the Court noted that Congress had provided protection against arbitrary tribal action: Tribal ordinances were subject to the approval of the Secretary of the Interior, and the Indian Civil Rights Act of $1968^{159}$ imposed upon tribes most of the limitations of the Bill of Rights, including due process and equal protection. Third, if the tribal regulation were viewed as an act of delegated federal authority, the Fifth Amendment might itself attach to the tribal action. ${ }^{160}$

Mazurie was an easy case. In an area in which Congress has "plenary power," one would expect the Court to defer to an explicit congressional command. Moreover, the situation of the non-Indians in Mazurie hardly seemed dire: Williams had long before found implied non-Indian consent to tribal territorial sovereignty, and Congress had expressly authorized the tribe to act. In addition to this ample notice of their obligations to obey tribal law, the civil rights of nonmembers seemed adequately protected as well.

But even if easy cases do not make bad law, they can warp perceptions of the surrounding legal domain. If the presence of express congressional authorization of tribal power made Mazurie simple, would the absence of such explicit permission in later cases give rise to a negative inference about tribal power in those settings? What should be done in intermediate situations, in which Congress has not expressly authorized the tribes to regulate non-Indians but has sent signals disapproving of state regulatory power over the same subject matter?

Reconsider Williams in this light. Congress had provided no clear answer to the jurisdictional conflict between state and tribal courts over reservation-based civil suits by non-Indians against tribal members. The Court had to choose between leaving the traditional approach in place, thereby placing the burden of inertia to obtain congressional relief from

155. Id.

156. $I d$.

157. Id. (quoting U.S. CONST. art. I, $\S 8$ ). The Court supported its conclusion that the delegation of legislative power is less troublesome when the recipient possesses independent authority over the subject matter by citing United States v. Curtiss-Wright Export Corp., 299 U.S. 304 (1936). See Mazurie, 419 U.S. at 557.

158. See Mazurie, 419 U.S. at 558 (quoting the passage from Williams found supra note 144).

159. Pub. L. No. $90-284, \S \S 201-203,82$ Stat. $73,77-78$ (1968) (codified as amended at 25 U.S.C. $\S \S 1301-1303(1994))$.

160. See Mazurie, 419 U.S. at 558 n. 12. 
tribal authority on those similarly situated to the non-Indian plaintiff, and abandoning those constructs and shifting the burden of legislative inertia to the tribes. Thus in Williams, as in most other federal Indian law disputes, where Congress has not settled the matter, resolution turns on the application of judicially constructed presumptions. Traditionally, these presumptions have favored the tribes, but perhaps by the mid-twentieth century this scheme was insufficiently sensitive to the changed circumstances in Indian country.

The Court in Williams stuck with the traditional approach, but it was not without some congressional guidance in doing so. Although Congress had never expressly either forbidden state courts or authorized tribal courts to exercise jurisdiction over non-Indian plaintiffs for reservation-based causes of action, it had provided, in Public Law 280, a means for Arizona to assume jurisdiction over such cases. ${ }^{161}$ The enactment of Public Law 280 thus gave rise to a negative inference about congressional intent to allow state courts to exercise jurisdiction over such cases in the absence of state compliance with the statute's opt-in scheme.

A negative inference concerning state power is not nearly as probative of the extent of tribal sovereignty as direct congressional authorization of tribal authority, of course. Indeed, if all that courts needed to resolve these disputes was the availability of a plausible negative inference, the tribes would prevail in all cases except those in which a federal statute or treaty expressly forbade them to regulate. This is so because the traditional constructs purport to set the relevant baseline of tribal power over nonIndians: The power exists unless the tribe has expressly ceded it away or Congress has expressly abrogated it. And yet it was the tension between the traditional approach and the changed circumstances in Indian country that gave rise to the extensive litigation about tribal authority over non-Indians that began in Williams.

Taken together, Williams and Mazurie support the notion that tribal sovereignty is territorial, reaching Indian and non-Indian alike on the reservation. Yet the express congressional authorization in Mazurie and the implied congressional disapproval of competing state-court jurisdiction in Williams made these decisions potentially distinguishable in later cases as being based on express or implied congressional intent rather than on the traditional baselines of tribal sovereignty. Moreover, one can easily imagine situations involving tribal regulation of nonmembers in which the stakes are more substantial than in these cases. ${ }^{162}$ An obvious contrast to Williams (a

161. See supra note 144 .

162. Williams simply narrows the cours available to non-Indians to collect reservation-based debts from tribal members. Presumably, creditors who wish to avoid tribal court have other means to protect their interests, and if they do not, nothing prevents them from censing to do business on the reservation. Mazurie did involve the prosecution of non-Indians for disobeying tribal law, but 
civil case with a non-Indian plaintiff) and Mazurie (a federal prosecution of a non-Indian) would be a tribal criminal prosecution of a non-Indian in tribal court. It did not take long for such a case to emerge.

\section{Tribal Criminal Jurisdiction over Nonmembers}

\section{Oliphant—Non-Indians and Criminal Jurisdiction}

In 1978, three years after it decided Mazurie, the Supreme Court handed down Oliphant $v$. Suquamish Indian Tribe ${ }^{163}$ A non-Indian who lived on the Port Madison Reservation of the Suquamish Indian Tribe in the State of Washington had allegedly assaulted a tribal police officer; another such non-Indian had allegedly crashed his vehicle into a tribal police car after a high-speed chase. The state could not prosecute them. ${ }^{164}$ The federal government could have, ${ }^{165}$ but apparently never did. The tribe sought to do so.

The absence of state-court jurisdiction in Oliphant was clearer than it was over the non-Indian's cause of action in Williams. Unlike in Williams, however, federal jurisdiction was present in Oliphant. Thus, the case turned on whether the federal jurisdiction was exclusive or whether the tribal court had concurrent jurisdiction. The issue was of practical as well as theoretical importance, because if the tribes lacked authority they would have no effective criminal sanctions available against non-Indians unless the United States Attorney-who might be located hundreds of miles awayprosecuted even minor offenses in federal court.

In Oliphant, Justice Rehnquist's majority opinion identified no treaty in which the tribe had ceded away its authority ${ }^{166}$ nor any federal statute that abrogated the tribe's police power. ${ }^{167}$ Under the traditional constructs, that

in a context in which Congress had incorporated tribal law into federal law, the prosecutor was the United States Attorney, and the prosecution was in federal court, with all constitutional procedural protections available. See Mazurie, 419 U.S. at 545-50.

163. 435 U.S. 191 (1978). For criticism of Oliphant, see, for example, Russel Lawrence Barsh \& James Youngblood Henderson, The Betrayal: Oliphant v. Suquamish Indian Tribe and the Hunting of the Snark, 63 MINN. L. REV. 609 (1979); and Robert A. Williams, Jr., The Algebra of Federal Indian Law: The Hard Trail of Decolonizing and Americanizing the White Man's Indian Jurisprudence, 1986 WIS. L. REV. 219.

164. States covered by Public Law 280 have criminal jurisdiction over Indian country found within them. See 18 U.S.C. $\S 1162$ (1994). At one point Washington had Public Law 280 jurisdiction over the Port Madison Reservation, but pursuant to a statutory procedure the state had retroceded this authority back to the federal government before these incidents occurred. See Oliphant v. Schlie, 544 F.2d 1007, 1012 (9th Cir. 1976). Absent a delegation of federal authority, such as that found in Public Law 280, state courts have criminal jurisdiction in Indian country only when both the victim and the perpetrator are non-Indian. See United States v. McBratney. 104 U.S. 621,624 (1881).

165. See 18 U.S.C. $\$ 1152$.

166. See Oliphant, 435 U.S. at 206.

167. See id. at 201-06. 
should have ended the matter-the tribe retained its inherent territorial sovereignty.

Indeed, even moving beyond this approach and examining the implications of related congressional actions, as might have been done in Williams and Mazurie, supports this conclusion. The Indian Civil Rights Act (ICRA) requires tribes to accord "any person" many of the criminalprocedure guarantees of the Bill of Rights, ${ }^{168}$ suggesting that Congress assumed that non-Indians could be prosecuted by tribes. ${ }^{169}$ The statute providing federal jurisdiction over offenses by non-Indians against Indians ${ }^{170}$ contains no hint that concurrent tribal jurisdiction is preempted.

Finally, basic systemic concerns support concurrent tribal jurisdiction. First, in addition to requiring tribes to respect basic civil liberties, ICRA provides that someone confined by a tribe may seek federal habeas corpus relief. ${ }^{171}$ Thus, non-Indian criminal defendants in tribal courts would be better protected against tribal action than are the non-Indian civil plaintiffs who are relegated to those courts under Williams, for the latter have no federal means to ensure compliance with ICRA. ${ }^{172}$ Second, because federal courts and prosecutors are not well situated to handle local crimes, as a functional matter the police power in Indian country should be allocated between the two local jurisdictions, the state and the tribe. Since Worcester, however, state authority in Indian country has been generally precluded absent clear congressional authorization, ${ }^{173}$ and there are obvious policy reasons for doing so. ${ }^{174}$ In a situation like that in Oliphant, where the state lacks such authorization, the most efficient approach would be for the tribe to prosecute minor offenses and to refer serious crimes to the United States Attorney. ICRA, in fact, encourages this approach because it limits the criminal sanctions that a tribe may impose..$^{75}$

Despite all these formal and functional justifications, the Court in Oliphant held that "Indians do not have criminal jurisdiction over non-

168. 25 U.S.C. § 1302 (1994).

169. Indeed, as introduced, the bill provided that its protections extended to "American Indians"; a later amendment changed this to "any person," suggesting that Congress assumed that tribes could have jurisdiction over non-Indians. See Frickey, supra note 68, at 1162-63.

170. See 18 U.S.C. $\$ 1152$.

171. See 25 U.S.C. \& 1303.

172. See Santa Clara Pueblo v. Martinez, 436 U.S. 49, $58-59$ (1978) (holding that ICRA provides no implied cause of action for civil relief against a tribe in federal court).

173. See supra text accompanying notes $41-44$.

174. See United States v. Kagama, 118 U.S. 375, 383-84 (1886) (lodging plenary power over Indian affairs in Congress rather than the states in part because tribes owe no allegiance to the states, receive no protection from them, and "[b]ecause of the local ill feeling, the people of the States where they are found are often their deadliest enemies").

175. At the time of Oliphant, ICRA limited tribal sanctions to six months in jail and/or a $\$ 500$ fine. See Indian Civil Rights Act of 1968, Pub. L. No. 90-284, $\$ 202(7) .82$ Stat. 73. 77. A 1986 amendment allows tribes to impose a term of one year in jail and/or a fine of $\$ 5000$. The current version is codified at 25 U.S.C. \$1302(7). 
Indians absent affirmative delegation of such power by Congress." 176 Because no treaty cession or congressional abrogation supported this conclusion, the Court fell back upon the only other theory of diminished tribal authority: the one prohibiting tribes from exercising powers "inconsistent with their status" ${ }^{177}$ as domestic dependent nations. In effect, the Court reopened a category of diminished tribal authority that had been thought closed forever since the Marshall Court. ${ }^{178}$ For the first time in 150 years, the Court took it upon itself to impose new limitations on tribal sovereignty.

Although Justice Rehnquist conceded that territorial sovereignty is "central" to the interests of any government, ${ }^{179}$ he concluded that tribal criminal jurisdiction over nonmembers was inconsistent with tribal status for two reasons. The first, a supposed "commonly shared presumption of Congress, the Executive Branch, and lower federal courts that tribal courts do not have the power to try non-Indians," ${ }^{180}$ in fact carried little weight. ${ }^{181}$ The second, and controlling, factor was the interest of the United States in protecting its citizens from "unwarranted intrusions on their personal liberty.... By submitting to the overriding sovereignty of the United States, Indian tribes therefore necessarily give up their power to try nonIndian citizens of the United States except in a manner acceptable to Congress." 182 Tribes had been "incorporat[ed] into the territory of the United States" - they are "domestic" sovereigns whose authority is subject to evaluation by the Court. ${ }^{183}$ Their submission to the United States made them "dependent" as well--their "exercise of separate power is constrained so as not to conflict with the interests of this overriding sovereignty." 184

As with the reservation-diminishment cases analyzed in Part III, Oliphant is subject to a realistic reading. The demographics in Oliphant made it a horrible test case for affirming tribal sovereignty in the modern

176. Oliphant v. Suquamish Indian Tribes, 435 U.S. 191, 208 (1978).

177. Id. (quoting the Court of Appeals below) (emphasis omitted).

178. See supra text accompanying notes 35-36, 61-65. In introducing his overview of the Marshall Court's decisions, Justice Rehnquist wrote that " $[w]$ e have already described some of the inherent limitations on tribal powers that stem from their incorporation into the United States." Oliphant, 435 U.S. at 209 (emphasis added). Before Oliphant, one would have thought that the Marshall Court had specified all such limitations.

179. Oliphant, 435 U.S. at 210.

180. Id. at 206.

181. Justice Rehnquist admitted that this factor was "not conclusive on the issue before us." Id. In fact, the assertion lacks historical support. See Frickey, supra note 68, at 1161-63.

182. Oliphant, 435 U.S. at 210. Apparently, the Court considered ICRA insufficiently protective of non-Indians because the Act did not prevent the use of an all-Indian jury, see Oliphant, 435 U.S. at 194 n.4, or a trial "according to [the tribe's] own customs and procedure." id. at 211 .

183. Id. at 209.

184. Id. 
context. The case was all over but for the rationale when, at the end of the first paragraph of the opinion, the first footnote reported that 2928 nonIndians and only fifty tribal members lived on the reservation. ${ }^{185}$ As Vine Deloria has written, this situation essentially mooted the argument for tribal sovereignty. ${ }^{186}$

The challenge for the Court in Oliphant, as in the diminishment cases, was to articulate a legalistic rationale for deferring to the current context. The opinion is subject to at least two readings. One-which is wildly counterfactual-is that the tribes willingly submitted to the overriding sovereignty of the United States. Another, much more plausible, understanding is that the outcome in Oliphant, like those in the diminishment cases, is not based on Indian consent. Under this vision, the United States involuntarily incorporated the tribes and achieved dominant sovereignty over them by an assertion of colonial prerogatives that eventually reached contemporary contextual fruition. The colonial process did not end at some point in the distant past. Instead, it is an ongoing process that is not even limited to new congressional exercises of its plenary power over Indian affairs. The ongoing colonization of the continent now includes a judicial role as well, adjudicating the depreciated status of tribal authority on a case-by-case basis.

Although this theory makes sense of Oliphant, it lacked precedential support. Recall that the Marshall Court had simply deferred to past colonial practice in limiting tribal authority to engage in land transactions and treaty relations. ${ }^{187}$ The Court embraced a political-question-like notion that, in a direct conflict between the colonizing nation and the indigenous entity, the colonial judiciary, as the "courts of the conqueror," ${ }^{188}$ must defer to the

185. See id. at 193 n.1.

186. According to Deloria:

The facts of the situation make the Indian argument not only moot but demonstrate that it was based on an idea of sovereignty having litule relation to actual reality. ... The doctrine of tribal sovereignty, perhaps relevant for a large reservation such as the Navajo with millions of acres of land and over 100,000 Indian residents, was expected to control the courr's thinking in defiance of the actual facts. Surely, here was an instance of a doctrine run amok.

When attomeys and scholars come to believe that doctrines have a greater reality than the data from which they are derived, all aspects of the judicial process suffer accordingly.

Vine Deloria, Jr., Laws Founded in Justice and Humanify: Reflections on the Content and Character of Federal Indian Law, 31 ARIZ L. REV. 203, 215 (1989).

187. See supra text accompanying notes 35-36.

188. In Johnson v. McIntosh, 21 U.S. (8 Wheat.) 543 (1823), Chief Justice Marshall stated:

We will not enter into the controversy, whether agriculturists, merchants, and manufacturers, have a right, on abstract principles, to expel hunters from the territory they possess, or to contract their limits. Conquest gives a title which the Courts of the conqueror cannot deny, whatever the private and speculative opinions of individuals may be, respecting the original justice of the claim which has been successfully asserted.

Id. at 588 . 
prerogatives of its sister political branch. ${ }^{189}$ In short, the Marshall Court considered tribes subservient to clear assertions of authority deemed necessary for the colonizing government to conduct the colonial process efficiently. Oliphant involved no conflict of this sort. Congress had never outlawed tribal criminal jurisdiction over non-Indians, and such tribal conduct did not threaten to undermine Congress's authority over Indian affairs. Instead of involving a conflict between sovereigns, Oliphant involved a matter of individual rights against governmental authority. But when the Marshall Court had encountered a case of arguable tribal mistreatment of a non-Indian, it took no steps to protect the person. ${ }^{190}$ In short, something new was at work in Oliphant.

If Oliphant lacked support in the venerable precedent it invoked, it bore a similarity to more recent cases. As Part III demonstrated, in the reservation-diminishment cases the Court has attempted to protect nonIndians found on allotted reservations from the authority of a government (the tribe) in which they have no vote. ${ }^{191}$ The setting in Oliphant was similar: Allotment had devastated the Port Madison Reservation. Because of the bizarre demographics there, non-Indian residents might have had "justifiable expectations" of immunity from tribal regulation similar to those supposedly held by the non-Indians in the diminishment cases. The problem was that in Oliphant there was no contention that the reservation had been diminished; thus, the Court had to limit tribal territorial sovereignty by limiting the sovereignty rather than the territory.

But what of Williams and Mazurie, where the Court concluded that non-Indians were subject to tribal power? The easiest distinction is that Oliphant involved tribal criminal jurisdiction-the ultimate tribal intrusion upon non-Indian personal liberty. In Mazurie, the criminal jurisdiction was federal, and the Constitution squarely attached to it. Williams involved tribal civil jurisdiction over a cause of action arising from the voluntary and commercial non-Indian presence in the quintessential region of Indian sovereignty, the Navajo Nation.

Nonetheless, taken as a whole, Williams, Mazurie, and Oliphant may lack coherence. From the standpoint of fairness, subjecting a non-Indian with a retail store in Indian country to the exclusive jurisdiction of tribal court for collection actions may be at least as troubling as subjecting a nonIndian reservation resident to tribal jurisdiction over minor crimes, when the tribe may impose only modest sanctions, must follow most of the guarantees found in the Bill of Rights, and is subject to federal habeas

189. See supra the opening paragraphs of Section II.B.

190. See supra text accompanying notes 61-65.

191. See supra notes 77-132 and accompanying text. 
corpus review. ${ }^{192}$ One is left wondering whether there is anything more substantial than a judicial gut instinct at work in these cases. ${ }^{193}$

\section{Duro-Nonmember Indians and Criminal Jurisdiction}

In a case following Oliphant, the Court again considered tribal criminal jurisdiction and produced an opinion that more clearly revealed the sources of the values at work in the judicial divestment of tribal authority. Duro $v$. Reina ${ }^{194}$ concerned tribal prosecution of a nonmember Indian-that is, a member of a tribe different from the one bringing the charges. Oliphant's concern about protecting the personal liberty of citizens against tribal intrusion foreordained the conclusion that the tribe lacked jurisdiction. ${ }^{195}$ Duro forthrightly acknowledged that, after Oliphant, tribes lack full territorial sovereignty. ${ }^{196}$ Instead, "the retained sovereignty of the tribes is that needed to control their own internal relations, and to preserve their unique customs and social order." 197 Duro distinguished Williams as involving tribal-court jurisdiction over a civil, not a criminal, matter. ${ }^{198}$ It concluded: "The exercise of criminal jurisdiction subjects a person not only to the adjudicatory power of the tribunal, but also to the prosecuting power of the tribe, and involves a far more direct intrusion on personal liberties." 199

192. See supra notes $168-175$ and accompanying text.

193. Perhaps these cases can be explained by asking whether the Coun could attribute its result to the action of a more democratic institution. In Mazurie. Congress had mandated that tribal legislative authority reached non-Indians, making it easy to suggest that any unfaimess was the work of Congress, not of the Court, and accordingly that attempts to change the outcome belonged in the legislative, not the judicial, process. Similarly, in Williams. Congress, through Public Law 280, had put in place a procedure whereby Arizona could obtain civil judicial jurisdiction over the non-Indian's cause of action, and Arizona had failed to use it. It is not easy to distinguish Williams and Oliphant on this score, however. Recall that, by virtue of Public Law 280 , Washington had possessed, and then retroceded, jurisdiction over the reservation involved in Oliphant. See supra note 164. The retrocession was valid only because the Secretary of the Interior accepted it. See Oliphant v. Schlie, 544 F.2d 1007, 1012 (9th Cir. 1976). Recall as well that Congress, in the Indian Civil Rights Act, has subjected tribal courts to most Bill of Rights limitations and to federal habeas corpus review. Thus, the Court in Oliphant could have upheld tribal jurisdiction on the ground that it was deferring to congressional, executive, and state action. Congress could easily have altered that result, of course. Thus, it is not clear that deference to the federal and state political branches can suppor the results in both Williams and Oliphant.

194. 495 U.S. 676 (1990).

195. In Duro, the Court noted that, in addition to civil-liberies justifications, Oliphant had relied upon the perceived shared assumptions of the federal branches. See id. at 705. Considering the weakness of this argument in Oliphant, see supra text accompanying notes 180-181, it is remarkable to read that a "review of history" concerning the issue in Duro was "somewhat less illuminating than in Oliphant, but tends to support the conclusion we reach," Duro, 495 U.S. at 688-89.

196. See Duro, 495 U.S. at 685.

197. Id. at 685-86.

198. See id. at 687.

199. Id. at 688. 
The Court in Duro attempted to make sense of the precedents by articulating a theory of consent to government. Tribal criminal jurisdiction over members is "justified by the voluntary character of tribal membership and the concomitant right of participation in a tribal government, the authority of which rests on consent." ${ }^{200}$ In contrast, nonmember Indians, like other American citizens, "are embraced within our Nation's 'great solicitude that its citizens be protected ... from unwarranted intrusions on their personal liberty." ${ }^{201}$ That the Court purported to be extraordinarily concerned about civil liberties was demonstrated by a remarkable passage that raises doubts about whether Congress - despite its plenary power over Indian affairs-could, as it later $\mathrm{did}^{202}$ authorize tribal criminal jurisdiction over nonmembers:

Our cases suggest constitutional limitations even on the ability of Congress to subject American citizens to criminal proceedings before a tribunal that does not provide constitutional protections as a matter of right. Cf. Reid v. Covert, 354 U.S. 1 (1957). We have approved delegation to an Indian tribe of the authority to promulgate rules that may be enforced by criminal sanction in federal court, [citing Mazurie], but no delegation of authority to a tribe has to date included the power to punish non-members in tribal court. We decline to produce such a result through recognition of inherent tribal authority. ${ }^{203}$

The citation to Reid v. Covert suggests the extent to which the Court in Duro viewed tribal prosecution of nonmembers as bizarre. In Reid, the Court, with no majority opinion, held that civilian dependents of military personnel stationed overseas could not be prosecuted for capital offenses at courts-martial, where trial by jury was unavailable. ${ }^{204}$ Thus, the Court in Duro implicitly compared the prosecution of Duro, an Indian, in the court of another tribe, which by federal statute was subject to most Bill of Rights limitations and to federal habeas corpus review, to the prosecution of Covert, who had allegedly murdered her serviceman husband in England, in a court-martial subject only to the limitations imposed by military

200. Id. at 694 .

201. Id. at 692 (quoting Oliphant v. Suquamish Indian Tribe, 435 U.S. 191, 210 (1978) (alteration in original)).

202. See infra note 321 and accompanying text.

203. Duro, 495 U.S. at 693-94.

204. In Reid v. Covert, 354 U.S. 1 (1957), Justice Black's plurality opinion, joined by Chief Justice Warren and Justices Douglas and Brennan, concluded that the Constitution applied overseas to federal acts taken against American citizens. Justices Frankfurter and Harlan, concurring separately in the judgment, limited their extraterritorial constitutional inquiry to capital cases. The other two participating Justices (Clark and Burton) dissented. For an examination of the extraterritorial effect of the Constitution, see generally GERALD L. NEUMAN, STRANGERS TO THE CONSTITUTION: IMMIGRANTS, BORDERS, AND FUNDAMENTAL LAW (1996). 
regulations. The prosecuting tribe seemingly took on the aura of the military - a closed, insulated institution deemed beyond ordinary principles of law by virtue of its unique status and its inscrutability to the judiciaryand the tribal court was compared to a court-martial rather than to a court of general jurisdiction. The tribe and the military had authority over their members, but neither had the requisite connection to Duro or Covert to subject them to extraordinary govemmental power unconstrained by full constitutional protections. ${ }^{205}$

In particular, the reference in Duro to Reid may have been motivated by a sense that, as in a trial by court-martial of a civilian dependent of a servicemember, a nonmember subjected to tribal-court prosecution does not receive a jury of peers selected from the broader community to which she belongs. The plurality opinion in Reid stressed that the military officers empaneled to conduct a court-martial "do not and cannot have the independence of jurors drawn from the general public or of civilian judges." 206 Similarly, Duro stated that "[t]ribal courts are often 'subordinate to the political branches of tribal governments." 207

Whatever analogies the imagination might generate, however, Duro's citation of Reid raises far more questions than it answers. Duro conceded that the Constitution does not apply to tribal action ${ }^{205}$ and that the Indian Civil Rights Act stops short of imposing upon tribes statutory limitations that parallel the Constitution in all respects. ${ }^{209}$ How, then, is it that general

205. The Court in Duro stated:

With respect to ... internal laws and usages, the tribes are left with broad freedom not enjoyed by any other govemmental authority in this country.... This is all the more reason to reject an extension of tribal authority over those who have not given the consent of the governed that provides a fundamental basis for power within our constitutional system.

Duro, 495 U.S. at 694 (citation omitted): cf. Reid, 354 U.S. at 19-23 (plurality opinion) (finding that Article I, Section 8, of the Constitution, which empowers Congress " [ $t$ ]o make Rules for the Government and Regulation of the land and naval Forces" and has been held to authorize trial of servicemembers without full Bill of Rights protections, did not apply to civilian dependents of servicemembers, because they were not in the military service).

206. Reid, 354 U.S. at 36 (plurality opinion).

207. Duro, 495 U.S. at 693 . The general legal community knows litule about the structure and operation of tribal courts. For a recent survey of tribal-court opinions that concludes that nonIndian criticism of tribal courts is often unfounded and grounded in ignorance, see Nell Jessup Newton, Tribal Court Praxis: One Year in the Life of Twenty Indian Tribal Courts, 22 AM. INDIAN L. REV. 285 (1998). As Joseph Singer has pointed out to me, it seems odd to assume the worst about tribal judges when, in light of the plenary power doctrine, they have every incentive to perform in a manner acceptable to Congress.

208. See Duro, 495 U.S. at 693.

209. See id. ("The Indian Civil Rights Act of 1968 provides some statutory guarantees of fair procedure, but these guarantees are not equivalent to their constitutional counterparns. There is, for example, no right under the Act to appointed counsel for those unable to afford a lawyer."). In addition, see Oliphant v. Suquamish Indian Tribe, 435 U.S. 191. 194 \& 194 n.4 (1978), which states that the Indian Civil Rights Act does not preclude tribes from using all-member juries in criminal cases. 
constitutional values so centrally inform the Duro opinion? ${ }^{210}$ What authorizes the Court to impose limitations beyond those already applied to tribes by Congress in ICRA? ? $^{21}$ In Reid, one issue was whether the constitutional limitations ordinarily applying to federal action operated extraterritorially. Duro dealt with inherent tribal power-which is beyond the reach of the Bill of Rights but subject to plenary congressional powerexercised within its customary territorial domain. Duro might suggest, in roundabout parallelism to Reid-which held that there is no categorical exception to the application of the Bill of Rights to extraterritorial federal action-that, when nonmembers are regulated, there is an exception to the nonapplication of the Bill of Rights to intraterritorial tribal action. Any effort to render this instinct doctrinally coherent seems doomed, however. If the Constitution applies to tribal action, it must protect members as well as nonmembers. Yet Duro made clear that members cannot invoke the Constitution when in conflict with their tribes. ${ }^{212}$

Thus, Reid and Duro seem to have less to do with each other than it might at first have appeared. Moreover, unlike Reid, where the source of judicial authority-the Constitution-was clear and its scope was contested, Duro does nothing to clarify either the source or the scope of the ongoing judicial power, first recognized in Oliphant, to truncate tribal sovereignty on a case-by-case basis at the behest of nonmembers. Yet the analogy between the jurisdiction of courts-martial over nonservicemembers

210. Cf. Oliphant, 435 U.S. at 210 ("But from the formation of the Union and the adoption of the Bill of Rights, the United States has manifested an equally great solicitude that its citizens be protected by the United States from unwarranted intrusions on their personal liberty.").

211. In addition, the result in Duro was inconsistent with another indicator of congressional intent, because it created a jurisdictional void in an area governed by federal statute. The Major Crimes Act, 18 U.S.C. $\$ 1153$ (1994), provides that, in Indian country, "[a]ny Indian" who commits one of the serious crimes listed in the statute is subject to federal prosecution. For less serious offenses by Indians, federal law extends into Indian country the criminal statutes governing federal enclaves, but contains an exception for "offenses committed by one Indian against the person or property of another Indian." 18 U.S.C. \& 1152 . Thus, these statutes provide that "nonmajor crimes" committed by one "Indian against the person or property of another Indian" fall outside federal jurisdiction. Because, in the absence of congressional authorization. the states have criminal jurisdiction in Indian country only when both the victim and perpetrator are non-Indian, see United States v. McBratney, 104 U.S. 621, 624 (1881), the inevitable conclusion is that tribal courts have exclusive jurisdiction over all "Indian/Indian" offenses that are not major crimes. Because these statutes use the term "Indian" rather than "member," their plain meaning is that tribal courts have exclusive jurisdiction over nonmajor offenses committed by all Indians, member and nonmember alike. By denying tribal courts jurisdiction over nonmembers, Duro thus seemed to create a jurisdictional void in which no sovereign could prosecute. Rather than viewing this absurd result as counseling against its holding, the Court in Duro simply suggested that the problem be fixed by reinterpretation of the statutes, by tribal consent to state jurisdiction, or by congressional legislation. See Duro, 495 U.S. at 697-98. These suggestions substitute either formless judicial revisionism or tribal capitulation for any serious grappling with the conundrum.

212. For the Court in Duro, tribal authority to regulate members free from constitutional restraint turned on their consent. See Duro, 495 U.S. at 694. This consent, however, cannot possibly rise to the level required to constitute a knowing and voluntary relinquishment of constitutional rights. After all, both members and nonmembers are American citizens. 
and tribal-court criminal jurisdiction over nonmembers, and the implicit assumption that the Constitution protects ordinary citizens from being dragged into military or tribal justice, may speak volumes about the background norms driving the ongoing judicial diminishment of tribal authority. ${ }^{213}$

\section{Tribal Civil Regulation of Nonmembers in the Absence of Congressional Approval}

Soon after it precluded tribal criminal jurisdiction over non-Indians in Oliphant, the Court considered tribal civil regulation of nonmembers. Once again, the legacy of allotment undermined the tribal position. And once again, the precedential effect was chaotic. Based on Oliphant, in the absence of congressional consent, one might have expected the Court to preclude all tribal authority over nonmembers. Alternatively, given Williams, which recognized exclusive tribal-court jurisdiction over civil cases brought by non-Indians against tribal members, one might have expected the Court to allow tribes to apply their civil laws to nonmembers. The Court took neither tack.

In Montana v. United States, ${ }^{214}$ a tribe outlawed nonmember hunting or fishing even on fee lands owned by nonmembers as the result of allotment. Justice Stewart's opinion in Montana began in Oliphant-like fashion, stating that "[t]he areas in which such implicit divestiture of sovereignty has been held to have occurred are those involving the relations between an Indian tribe and nonmembers of the tribe." ${ }^{115} \mathrm{He}$ continued: "[E]xercise of tribal power beyond what is necessary to protect tribal self-government or to control internal relations is inconsistent with the dependent status of the tribes, and so cannot survive without express congressional delegation." 216 $\mathrm{He}$ concluded that "[s]ince regulation of hunting and fishing by nonmembers of a tribe on lands no longer owned by the tribe bears no clear relationship to tribal self-government or internal relations, the general principles of retained inherent sovereignty did not authorize" the tribe to regulate as it wished. ${ }^{217}$ More generally, he read Oliphant for the proposition that "the inherent sovereign powers of an Indian tribe do not extend to the activities of nonmembers of the tribe." 218

213. See infra Section V.B.

214. 450 U.S. 544 (1981).

215. Id. at 564 (quoting United States v. Wheeler, 435 U.S. 313, 326 (1978)). The language quoted from Wheeler is dictum. Wheeler concerned whether a tribe retained inherent criminal jurisdiction over its members. The Court in Wheeler upheld tribal authority on those facts.

216. Id.

217. Id. at 564-65.

218. Id. at 565 . 
Justice Stewart then rapidly undercut these seemingly clear, if drastic, principles by announcing what have become known as the "Montana exceptions":

To be sure, Indian tribes retain inherent sovereign power to exercise some forms of civil jurisdiction over non-Indians on their reservations, even on non-Indian fee lands. A tribe may regulate, through taxation, licensing, or other means, the activities of nonmembers who enter consensual relationships with the tribe or its members, through commercial dealing, contracts, leases, or other arrangements. [Citing, e.g., Williams.] A tribe may also retain inherent power to exercise civil authority over the conduct of nonIndians on fee lands within its reservation when that conduct threatens or has some direct effect on the political integrity, the economic security, or the health or welfare of the tribe. ${ }^{219}$

These two categories are far from clear. As to the first, Duro did later identify "consent" as the source of tribal authority. ${ }^{220}$ But it must seem ironic to the non-Indian merchant in Williams that his implied consent to exclusive tribal-court civil jurisdiction was valid, while Oliphant's choice to reside in Indian country could not support tribal criminal jurisdiction. More generally, an examination of cases following Montana indicates that the Court has not taken a consistent approach to nonmember consent to tribal authority. ${ }^{221}$ As to the second exception, tribal civil authority might extend to nonconsenting nonmembers who undermine core tribal interests.

Two later cases concerned tribal civil regulation of nonmembers on non-Indian property. In the first, Brendale $v$. Confederated Tribes \& Bands of the Yakima Indian Nation, ${ }^{222}$ the tribe sought to zone all reservation property, ircluding nonmember fee lands. Four Justices, in an opinion by Justice White, would have revised the second Montana exception to deny tribal authority to zone nonmember land. ${ }^{223}$ For White, that exception merely identified instances in which the tribe could complain to county zoning authorities that activities on nonmember land interfered with the use

219. Id. at 565-66 (citations omitted).

220. See supra text accompanying note 200.

221. See Frickey, supra note 11, at 1768-77 (concluding that criminal jurisdiction cases turn on tribal membership, that tribal-court civil jurisdiction and taxation cases turn more on the traditional presumption that presence in a territory amounts to implied consent to governmental authority, and that civil regulatory cases are too incoherent to support any obvious paradigm based on consent). But see L. Scott Gould, The Consent Paradigm: Tribal Sovereignty at the Millennium, 96 COLUM. L. REV. 809 (1996) (arguing that a "consent paradigm" best explains the cases).

222. 492 U.S. 408 (1989). For an insightful critique, see Joseph William Singer, Sovereignty and Property, 86 Nw. U. L. REv. 1 (1991).

223. See Brendale, 492 U.S. at $428-30$. 
of neighboring Indian land. ${ }^{224}$ Three Justices, in an opinion by Justice Blackmun, would have reread the second exception to provide presumptive tribal authority to zone throughout the reservation. ${ }^{23}$ The remaining two Justices controlled the outcome. Justice Stevens, joined by Justice O'Connor, argued that context should control. He concluded that the tribe could zone nonmember land in the closed area of the reservation, where almost all the land was Indian trust land, the area was basically wilderness and had significant cultural and religious significance for the tribe, and the tribe had maintained its general authority to exclude nonmembers ${ }^{226}$ and had retained "its legitimate interest in the preservation of the character of the reservation." 227 In contrast, he concluded that the tribe had no power to zone nonmember land in the opened part of the reservation, where the tribe lacked the general authority to exclude nonmembers, where much of the land was owned by nonmembers and had been developed, and where eighty percent of the residents were nonmembers. ${ }^{228}$ In Stevens's conclusion that the "open area has lost its character as an exclusive tribal resource," 229 one hears the echo of the realistic reading of the diminishment cases, under which the issue is whether the area in question has lost its "essential Indian character." 230

The final case involving tribal civil regulation of nonmembers, South Dakota v. Bourland, ${ }^{231}$ has already been mentioned. ${ }^{232}$ Bourland concerned whether the Cheyenne River Sioux Tribe could regulate nonmember hunting and fishing in a federal recreation area located on the reservation but open to the general public. The federal statute creating the recreation area did not clearly resolve the issue. The case seemed similar to Oliphant and the later cases involving the implicit divestiture of retained tribal sovereignty, for it appeared to involve whether, in the absence of clear congressional guidance, the Court would itself further diminish tribal territorial sovereignty by limiting the sovereignty.

Consider several ways in which the precedents interacted in the Bourland situation. First, consistent with Williams's broad affirmation of tribal-court civil jurisdiction over non-Indian plaintiffs, the Court could have concluded that the voluntary presence of nonmembers on the reservation subjected them to tribal civil authority. To be sure, that

224. See id. at $430-31$.

225. See id. at 462 (Blackmun, J., joined by Brennan \& Marshall, JJ., concurring in pan and dissenting in part).

226. See id. at $438-44$ (Stevens, J., joined by $\mathrm{O}^{\prime}$ Connor, J., announcing the judgment).

227. Id. at 442 .

228. See id. at $444-47$

229. Id. at 447.

230. See supra text accompanying notes $99-106,112-113,126,131-132$.

231. 508 U.S. 679 (1993).

232. See supra text accompanying notes 7-8. 
expansive view of nonmember consent might seem inconsistent with Montana, but a potentially important distinction existed: In Bourland, nonmembers were on federal land, not on nonmember fee land as in Montana, and thus notions of personal liberty associated with property ownership were arguably irrelevant. As this suggests, a second option in Bourland would have been to expand the concern about nonmember civil rights recognized most clearly in the criminal jurisdiction cases to create a flat rule prohibiting tribal civil, as well as criminal, regulation of nonmembers regardless of their location on the reservation. But that outcome would have been inconsistent both with the result in Brendale, which allowed the tribe to zone nonmember land in the closed reservation area, and with the "Montana exception" that seemingly recognized tribal authority to regulate nonmembers in compelling circumstances. It also would have been in great tension with Williams, which assumed that the tribal court would apply tribal law in exercising its exclusive jurisdiction over a civil action brought by a non-Indian. Alternatively, a third approach would have been to limit Montana and Brendale to the circumstance of nonmember presence on nonmember fee lands, thereby allowing the tribe to regulate nonmembers in the recreation area. Alas, this option also was fraught with problems, for it would have been in tension with the controlling two-Justice opinion in Brendale, in which Justice Stevens stressed that when a reservation area is opened and the tribe loses the ability to exclude nonmembers from it, the tribe may well have lost its civil regulatory authority as well.

Perhaps understandably in light of this precedential chaos, Justice Thomas's majority opinion in Bourland avoided all of these options. In effect, it abandoned the unstated premise of all the implicit-divestiture cases - that the absence of clear congressional intent concerning tribal authority to regulate nonmembers left a void to be filled by the Court as a matter of federal common law. But what was wrong with this premise, Justice Thomas implied, was not the judicial recognition of new limitations on tribal sovereignty. Rather, the mistake was in assuming that Congress had not resolved the issue against tribal sovereignty in the first place.

Justice Thomas essentially returned to the approach taken in the diminishment cases, where the Court consistently stated that only clear congressional intent could result in diminishment, yet always found diminishment where the purpose and effect of the congressional action were to destroy the Indian character of the reservation area. ${ }^{233} \mathrm{He}$ wrote that, "regardless of whether land is conveyed pursuant to an Act of Congress for homesteading or for flood control purposes, when Congress has broadly opened up [reservation] land to non-Indians, the effect of the transfer is the

233. See supra text accompanying notes 127-129. 
destruction of pre-existing Indian rights to regulatory control." 23s The message of Bourland was that Congress, not the Court, bore the responsibility for the loss of tribal geographical sovereignty.

In a sense, Bourland might seem a somewhat refreshing exercise in candor. Of course Congress was the institution that opened up the reservations and created the current jurisdictional nightmare. All the diminishment cases, and every implicit-divestiture case except Bourland, involved the current consequences of the congressionally adopted, abandoned, but never undone policy of allotment, the general purpose of which was to destroy reservations and to encourage Indian assimilation. As explained earlier, ${ }^{235}$ such a general purpose is usually a useful tool in statutory interpretation where clear statutory text or legislative intent is absent, as it has been in all these cases. When relying upon general purpose seems consistent with the most practical outcome on the facts, deferring to it can be particularly attractive. ${ }^{236}$ At all events, such an approach ties the result in the case to congressional lawmaking, not to judicial freewheeling in the absence of a statutory framework. Bourland might seem a useful corrective to the unconstrained judicial policy judgments most clearly evident in Oliphant and Duro, where a creeping constitutionalism seems to have invaded federal Indian law and precluded tribal criminal jurisdiction over nonmembers even though the Constitution does not apply to tribal action. In addition, because it provides a potentially clear rule about the abrogation of tribal regulatory power over nonmembers when Congress has opened reservation areas, Bourland might seem preferable to the incoherent aggregation of Justices concerning a similar question of tribal zoning power in Brendale.

Unfortunately, there are nonetheless extreme problems with the result and rationale in Bourland. As in the diminishment cases, the Court in Bourland purported to adhere to the clear-statement canon concerning congressional intent ${ }^{237}$ while abandoning it as a practical matter. Both the diminishment cases and Bourland used a judicial sleight of hand, creating a rule of law to trump the legal effect of the clear-statement canon. In the diminishment cases, the rule concerns the legal effect of the presence of "magic language" in the allotment statute or agreement; ${ }^{238}$ in Bourland it involves the legal effect upon tribal sovereignty of broadly opening the reservation to nonmembers.

234. Bourland, 508 U.S. at 692 (emphasis added).

235. See supra text accompanying note 127.

236. Thus, a purposive approach to statutory interpretation generally embraces the best contextual answer consistent with the purposes animating the statute. See HART \& SACKS, supra note 127 , at $1374-80$.

237. See Bourland, 508 U.S. at 687.

238. See supra text accompanying notes 87-89.111. 
Moreover, although the diminishment cases can at least be defended as deferring to the "justifiable expectations" of non-Indians, ${ }^{239}$ no such contextual factors supported Bourland. Indeed, if the reasonable expectations of nonmembers were all that were at stake, they would seem amply protected merely by posting signs indicating that entry into the recreational area subjected the nonmember to tribal hunting and fishing laws. A nonmember hunting or fishing on private reservation land might have "reasonable expectations" related to basic Anglo-American assumptions about the autonomy of property owners. It is not all that surprising that the Court in Montana protected those interests. But a nonmember driving onto the reservation to hunt or fish on public land can claim no such expectations. If, as both the diminishment cases and the implicit-divestiture cases suggest, the basic judicial instinct is to protect the reasonable reliance interests of nonmembers while preserving whatever residual tribal sovereignty remains consistent with that approach, then Bourland is a mystery.

Furthermore, as the next Section explains, Bourland's solicitude for nonmember freedom from tribal civil regulation even when no obvious reliance interest was at stake was radically inconsistent with the results in cases concerning tribal taxation of nonmembers that had been decided a decade earlier but were nowhere even mentioned in the Bourland opinion. The tension between the Court's approach to tribal general civil regulation of nonmembers and tribal taxation of nonmembers seems particularly incoherent. After all, taxation is usually conceptualized as simply a kind of civil regulation. Nonetheless, because the taxation cases take a strikingly different approach to the importance of nonmember consent and reliance interests, they require separate treatment.

\section{E. Tribal Taxation of Nonmembers}

Two years after Oliphant precluded tribal criminal jurisdiction over non-Indians and one year before Montana limited many aspects of tribal civil regulation of nonmembers, Washington $v$. Confederated Tribes of the Colville Indian Reservation ${ }^{240}$ upheld a tribal sales tax imposed on nonmembers who entered the reservation to buy products. Legalistically, the Court concluded that "[t]he power to tax transactions occurring on trust lands and significantly involving a tribe or its members is a fundamental attribute of sovereignty" ${ }^{241}$ that Congress had never abrogated, that the federal government had assumed to be valid, and that was not "inconsistent

239. Hagen v. Utah, 510 U.S. 399, 421 (1994); see also supra text accompanying notes 112 113.

240. 447 U.S. 134 (1980).

241. Id. at 152 . 
with the overriding interests of the National Government." 2+2 Thus, the tribe could impose the tax despite its domestic dependent status.

Presumably, the Court found the case far afield from Oliphant-the only implicit-divestiture case then on the books-because it is difficult to perceive any risk of unfairness to nonmembers. Unlike in the diminishment cases as well as in Oliphant and its progeny, where Congress had opened up the reservation to nonmembers and thereby encouraged them to take important actions based on their potentially reasonable reliance upon the expectation of freedom from tribal regulation, in Confederated Tribes all the nonmember had to do to avoid the tax was to decline to engage in the transaction. A year later in Montana, the Court seemingly recognized this factor when it cited Confederated Tribes in support of its exception to the preclusion of tribal regulatory authority where nonmembers have voluntarily entered into relationships with tribes. ${ }^{243}$ That raises the question, however, why over a decade later the Court in Bourland protected nonmembers who could have avoided tribal regulation simply by not hunting or fishing in the recreational area. Legalistically, the difference could be that the transactions occurred on tribal trust land in Confederated Tribes. Because the tribe had the authority to exclude nonmembers from this land, it could condition their entry upon consent to pay a tax. Unfortunately, this explanation does not make sense of another, more important tribal taxation case.

In Merrion $v$. Jicarilla Apache Tribe, ${ }^{244}$ the tribe had entered into longterm mineral leases under which nonmember companies extracted oil and gas from tribal lands and paid the tribe a royalty. Many years later, the tribe imposed a severance tax upon the extraction of these minerals. The leases in question were silent concerning the imposition of tribal taxes. The practical effect of the tax was to increase the tribe's, and to decrease the companies', net revenue. ${ }^{245}$ Understandably, the companies challenged the

242. Id. at 153. The Court's explanation of why tribal taxation of nonmembers was consistent with domestic dependent status was extraordinarily cursory:

Tribal powers are not implicitly divested by virtue of the tribes' dependent status. This

Court has found such a divestiture in cases where the exercise of tribal sovereignty would be inconsistent with the overriding interests of the National Govemment, as when the tribes seek to engage in foreign relations, alienate their lands to non-Indians without federal consent, or prosecute non-Indians in tribal courts which do not accord the full protections of the Bill of Rights. ... In the present cases, we can see no overriding federal interest that would necessarily be frustrated by tribal taxation. ... Id. at 153-54 (citations omitted).

243. Recall that this "Montana exception" stated that "[a] tribe may regulate, through taxation, licensing, or other means, the activities of nonmembers who enter consensual relationships with the tribe or its members, through commercial dealing, contracts, leases, or other arrangements." Montana v. United States, 450 U.S. 544, 565-66 (1981) (citing, among other cases, Confederated Tribes, 447 U.S. at 152-54).

244. 455 U.S. 130 (1982).

245. See id. at 167 (Stevens, J., dissenting). 
tax, which surely appeared to them to be a unilateral rewriting of the original deal. Moreover, unlike the potential nonmember one-shot purchasers in Confederated Tribes, the companies in Merrion had a longterm contractual relationship with the tribe and had presumably sunk significant costs into this project in reliance upon their understanding of the original arrangement.

As in Confederated Tribes, Congress had not clearly precluded the tax at issue in Merrion, and the tax did involve tribal trust lands. A huge potential distinction existed, however: Because the tribe in Merrion had entered into the leases, arguably it did not have the authority to exclude the nonmember companies. ${ }^{246}$ Justice Marshall's majority opinion in Merrion nonetheless upheld the tribal authority to tax, concluding that "there is a significant territorial component to tribal power" ${ }^{247}$ and that "[t]he power to tax is an essential attribute of Indian sovereignty because it is a necessary instrument of self-government and territorial management." 248 Of course, these premises would seem equally applicable to all the implicit-divestiture cases, for surely criminal (Oliphant, Duro) and civil (Montana, Brendale, Bourland) regulation is likewise "a necessary instrument of selfgovernment and territorial management."

Under Merrion, a tribe can tax a nonmember company with presumably significant "justifiable expectations" to the contrary in a circumstance where the tribe has agreed to allow the company on the reservation. Yet, absent congressional authorization or clear nonmember consent, a tribe cannot criminally sanction nonmember residents of the reservation (Oliphant, Duro), cannot regulate nonmembers who hunt or fish on nonmember fee lands unless their conduct threatens a core tribal interest (Montana), might be able to zone some nonmember lands on the reservation (Brendale), and yet cannot even regulate the hunting or fishing of transient nonmembers who come to a federal recreational area within the reservation (Bourland). Doctrinally, perhaps the best reconciliation of the cases is that when Congress destroys the tribal power to exclude nonmembers-as the Court understands the allotment statutes to have done with respect to nonmember landowners-the congressional action should

246. In addition, because the tribe was the sole royalty holder, the oil companies could not rely upon opposition to the tax from private royalty holders. See Frickey, supra note 11, at 1171 n.193.

247. Merrion, 455 U.S. at 142.

248. Id. at 137. Justice Marshall also disposed of another argument, rooted in Oliphant, see supra text accompanying notes $180-181$, by concluding that the federal governmental branches had assumed that tribes possess the power to tax nonmembers, see Merrion, 455 U.S. at 139-41.

In Merrion, the Court stressed that, pursuant to a requirement in the tribal constitution, the Secretary of the Interior had approved the tribal tax before it took effect. See id. at 135-36, 141. $150 \&$ n.16, 155. In a circumstance where no tribal or federal law required Secretarial approval of such a tax, however, the Court found the tax to be within the tribe's inherent authority. See KerrMcGee Corp. v. Navajo Tribe, 471 U.S. 195 (1985). 
be broadly construed to immunize nonmembers from unilateral tribal regulation. In contrast, in the absence of congressional intrusion upon tribal sovereignty, the tribe may condition nonmember entry upon consent to tribal regulation (Confederated Tribes), and tribal waiver of the power to exclude, as an action in derogation of sovereignty, shall, according to established canons of construction, be narrowly construed, such that the tribe shall be held as not having lost it or other sovereign powers unless the tribe has explicitly waived them as well (Merrion). ${ }^{249}$

One gets the sense, though, that such exercises in case-crunching hold little hope for rationalizing for very long as unruly an area as federal Indian law. ${ }^{250}$ Every option seems fraught with normative and doctrinal dilemmas. To take a final example, consider whether the Court should overrule Merrion and simply view the tribal power to exclude as including the lesser power of the tribe to admit nonmembers and subject them to civil regulation. The normative unattractiveness of this option, which would destroy one of the few remaining zones of vital tribal authority, should be evident. Moreover, its contribution to doctrinal coherence would be problematic, because even this partial reconstruction is in tension with the final cluster of cases involving tribal attempts to regulate nonmembers. The next Section turns to these cases. As with tribal taxation of nonmembers, tribal-court jurisdiction over nonmember defendants began as a unique category of civil regulation in which tribes possessed authority transcending the grudging general regulatory power captured in the Montana exceptions. Unlike tribal taxation, however, tribal-court civil jurisdiction over nonmembers has been eroded by recent precedent.

\section{F. Tribal-Court Jurisdiction in Civil Cases Involving Nonmember Defendants}

When the Supreme Court first considered whether a tribal court could hear a civil case brought by a member against a nonmember defendant, it had already decided Williams, Oliphant, Montana, and Merrion. These cases suggested at least three options. First, the Court could equate tribalcourt criminal and civil jurisdiction by holding that non-Indians are just as immune from defending civil cases in tribal court as Oliphant renders them immune from defending criminal charges there. Many of the factors

249. This theory may not adequately explain Duro, which involved a nonmember Indian criminal defendant living on an unallotted reservation (and thus one where Congress had not expressly extinguished the tribe's authority to exclude a large category of nonmembers). The Court in Duro, however, did leave open the question whether a tribe could obtain criminal jurisdiction by consent of the nonmember defendant "in retum for [the] tribe's agreement not to exercise its power to exclude [the] offender from tribal lands." Duro v. Reina. 495 U.S. 676, 689 (1990).

250. So I have argued before. See Frickey, supra note 11, at 1767-68, 1775-80. 
supporting Oliphant-the supposed unfairness of subjecting non-Indians to tribal court, where unique tribal laws and customs are followed and only tribal members may be on the jury, all beyond the reach of the Constitution ${ }^{251}$ - would seem applicable in the context of non-Indian civil defendants as well. Yet such a flat prohibition would be in great tension with Williams, which relegates a nonmember civil plaintiff to tribal court when suing a member on a cause of action arising in Indian country. Second, the Court could equate tribal-court civil jurisdiction with tribal civil regulatory power by concluding that tribal-court jurisdiction over nonmember civil defendants must satisfy one of the "Montana exceptions." ${ }^{252}$ Again, this outcome would be in tension with Williams. Third, the Court could conclude that, like taxation in Merrion, civil judicial jurisdiction is a fundamental attribute of tribal sovereignty, the retention of which is consistent with the shared assumptions of the federal governmental branches. This outcome would, of course, be consistent with Williams, but it would raise the question why tribal-court civil jurisdiction is privileged while, under Montana, tribal-council civil regulatory authority is not.

In this jurisprudential land of ultimate incoherence-or at least in which every case is distinguishable from what has come before-it is perhaps not surprising that, at least at first, the Court followed none of these options. ${ }^{253}$ Instead, the Court attempted to construct an institutionally sensitive approach to tribal-court jurisdiction in civil cases involving nonmember defendants.

251. See supra note 182 .

252. See supra text accompanying notes $219-221$.

253. The Court did not, as it had done in Oliphant, disqualify tribal courts from hearing cases against non-Indians, perhaps because, as Williams had suggested long before, civil cases raise fewer civil liberties concerns than criminal cases. The Court did not even create, along the lines of Montana, a rule against tribal adjudicatory power subject to exceptions. Perhaps the explanation here is simply the distinction between tribal judicial jurisdiction, which was recognized over nonmember plaintiffs in Williams, and the tribal regulatory jurisdiction looked upon with disfavor in Montana. It is no secret that judges have often made more generous assumptions about the likelihood of the legitimate exercise of authority by judges than by others possessing the coercive power of govemment. Compare, e.g., Shuttlesworth v. City of Birmingham, 394 U.S. 147 (1969) (striking down an ordinance giving local officials complete discretion to issue parade permits as a prior restraint upon expressive activity), with Walker v. City of Birmingham, 388 U.S. 307 (1967) (upholding an injunction incorporating such an unconstitutional prior restraint system). Yet neither did the Court embrace Merrion-like essentialist notions of tribal sovereignty and return all the way to Williams by assuming that nonmembers in tribal court have no cognizable complaints. A potentially key distinction is that the nonmember oil companies in Merrion and the nonmember merchant in Williams had voluntarily entered Indian country for commercial purposes and, arguably, implicitly consented to take tribal laws and institutions as they found them. In contrast. at least many potential nonmember civil defendants in cases arising in Indian country could be fee-simple landowners (as in Montana and Brendale), residents (as in Oliphant), or others entitled to enter the reservation for noncommercial purposes (as in Bourland) pursuant to explicit congressional actions destroying the tribal authority to exclude nonmembers, which arguably create "justifiable expectations" inconsistent with full tribal territorial sovereignty. 
In the first case, National Farmers Union Insurance Cos. v. Crow Tribe, ${ }^{254}$ the Court refused to provide a categorical answer to the question whether a tribal court may exercise civil jurisdiction over a nonmember defendant. It did hold that federal courts have federal-question jurisdiction to hear challenges to tribal-court jurisdiction over nonmembers. ${ }^{255}$ But the Court then undercut the utility to nonmembers of this jurisdiction by declining to expand the rationale of Oliphant to preclude tribal-court civil jurisdiction over them. Oliphant was distinguishable because, although the shared assumptions of the federal branches counseled against criminal jurisdiction, ${ }^{256}$ they provided no clear answer concerning civil jurisdiction. 257 Thus, "the existence and extent of a tribal court's jurisdiction will require a careful examination of tribal sovereignty, the extent to which that sovereignty has been altered, divested, or diminished, as well as a detailed study of relevant statutes, Executive Branch policy as embodied in treaties and elsewhere, and administrative or judicial decisions." 258 The Court concluded that the best institution to have frontline responsibility for this inquiry was the tribal court itself. ${ }^{259}$

Two years later, in Iowa Mutual Insurance Co. v. LaPlante, ${ }^{260}$ the Court applied this exhaustion requirement to federal suits using diversity jurisdiction to attack tribal-court jurisdiction. Iowa Mutual contained two important elaborations upon National Farmers. First, it clarified that nonmembers were required to exhaust all tribal-court remedies, including appellate ones. ${ }^{261}$ Second, in a mind-bending passage, it seemed to invoke Montana, which found no tribal civil regulatory power over nonmembers

254. 471 U.S. 845 (1985).

255. See id. at 852-53.

256. See supra text accompanying notes $180-181$.

257. Congress had provided federal criminal jurisdiction over the offense in Oliphant, but no federal civil jurisdiction over the alleged ton in National Farmers. See National Farmers, 471 U.S. at 854. In addition, unlike the inconsistent federal executive understandings in Oliphant, see Oliphant v. Suquamish Indian Tribe, 435 U.S. 191, 199-201 (1978), an Altomey General opinion had concluded that tribal cours at least sometimes had jurisdiction over a civil case with a nonmember defendant, see National Farmers, 471 U.S. at 854-55.

258. National Farmers, 471 U.S. at 855-56 (footnote omitted).

259. The Court stated:

We believe that examination should be conducted in the first instance in the Tribal Court itself. Our cases have often recognized that Congress is committed to a policy of supporting tribal self-government and self-determination. That policy favors a rule that will provide the forum whose jurisdiction is being challenged the first opportunity to evaluate the factual and legal bases for the challenge. Moreover the orderly administration of justice in the federal court will be served by allowing a full record to be developed in the Tribal Court before either the merits or any question conceming appropriate relief is addressed.... Exhaustion of tribal court remedies, moreover, will encourage tribal courts to explain to the parties the precise basis for accepting jurisdiction, and will also provide other cours with the benefit of their expertise in such matters in the event of further judicial review.

Id. at 856-57 (footnotes omitted).

260. 480 U.S. 9 (1987).

261. See id at 16-17. 
except in exceptional circumstances, ${ }^{262}$ in support of a presumption favoring tribal-court civil jurisdiction over nonmembers:

Tribal authority over the activities of non-Indians on reservation lands is an important part of tribal sovereignty. . . . Civil jurisdiction over such activities presumptively lies in the tribal courts unless affirmatively limited by a specific treaty provision or federal statute. "Because the Tribe retains all inherent attributes of sovereignty that have not been divested by the Federal Government, the proper inference from silence... is that the sovereign power ... remains intact." 263

National Farmers held out the promise of a tribal-federal judicial relationship under which tribal courts could flourish. ${ }^{264} \mathrm{~A}$ puzzling problem lurked just below the surface, however. The Court in National Farmers never explained how requiring exhaustion of tribal-court remedies by nonmember defendants in civil cases could be squared with Montana's approach to tribal civil regulatory jurisdiction. The Court in National Farmers did not specify whether, in the absence of a governing federal treaty or statutory provision, tribal-court jurisdiction in these cases was presumptively valid, presumptively invalid, or turned on some other inquiry, such as whether the reservation context had retained a sufficiently Indian character or whether the dispute in question implicated important tribal interests. Absent such guidance, the Court left the legal community with only a surmise: Presumably the exhaustion requirement was not merely a charade-tribal courts must have valid jurisdiction over at least many civil cases involving nonmember defendants, mustn't they? That Iowa Mutual later stated that tribal courts presumptively have jurisdiction over nonmember civil defendants made sense in light of the exhaustion policy, but did nothing to resolve the tension between this approach and Montana.

When, after a decade, the Court returned to the tension between National Farmers and Montana, it took up the problem in the context of facts that failed to illuminate the tribal interests at stake. Strate v. A-l Contractors $^{265}$ arose out of an automobile accident on a state highway

262. See supra text accompanying notes $219-221$.

263. Iowa Mutual, 480 U.S. at 18 (quoting Merrion v. Jicarilla Apache Tribe, 455 U.S. 130. 149 n.14 (1982)). In addition to Montana, the Court cited Washington v. Confederated Tribes of the Colville Indian Reservation, 447 U.S. 134 (1980), discussed supra text accompanyıng notes 240-243, which allowed tribes to impose a sales tax upon transient non-Indian purchasers of goods in Indian country, and Fisher v. District Court, 424 U.S. 382 (1976), which precluded statecourt jurisdiction over adoption or custody proceedings concerning reservation-domiciled Indian children.

264. See, e.g., Frank Pommersheim, Braid of Feathers: American Indian law and CONTEMPORARY TRIBAL LIFE 50, 57, 81, 93, 96-98, 194 (1995).

265. 520 U.S. 438 (1997). 
running through an Indian reservation. A-1 Contractors, a non-Indian company, was performing road work on the reservation as a subcontractor for a tribal corporation. An A-1 gravel truck driven by a non-Indian employee collided with a car driven by a non-Indian, Mrs. Fredericks, who was married to a tribal member and who permanently resided on the reservation. Her children (who were tribal members) and she brought suit against A-1 in tribal court. After exhausting all tribal-court remedies, A-1 sought federal judicial relief from the suit. By this time, Mrs. Fredericks stood alone as the plaintiff, ${ }^{266}$ leaving (from the standpoint of tribal interests) an unpalatable fact pattern in which all parties in the case were non-Indian.

The division in the Eighth Circuit, sitting en banc, demonstrated the plasticity of the precedents. The majority of the Eighth Circuit, which denied tribal-court jurisdiction, considered Montana the controlling precedent on the authority of tribal institutions, including courts, to regulate nonmembers in civil matters. ${ }^{267}$ For the majority, National Farmers was a case about exhaustion of tribal remedies, not a decision that tribal courts actually had jurisdiction over nonmember civil defendants. ${ }^{268}$ The language in Iowa Mutual indicating wide-ranging tribal-court jurisdiction over nonmember civil defendants was narrowly understood as applying only to those circumstances in which, under Montana, the tribe would have civil regulatory jurisdiction as well. ${ }^{269}$ Of course, the dissenters took the opposite tack. Relying on the helpful language in Iowa Mutual, they concluded that the tribal court presumptively had jurisdiction over civil suits arising within reservation borders. ${ }^{270}$ Montana was narrowly construed as involving only the implicit divestiture of tribal sovereignty over nonmember conduct on nonmember fee lands, not nonmember conduct throughout the reservation in general or even on portions of the reservation, like the state highway, where the tribe had lost the ability to exclude nonmembers. ${ }^{271}$

The contesting blocs of the Eighth Circuit thus manipulated, but could not resolve, the underlying tension between Montana and National Farmers. The majority of the Eighth Circuit privileged Montana, thereby identifying a unified approach to tribal authority over nonmembers at the risk of transforming the exhaustion requirement of National Farmers and Iowa Mutual into a pointless exercise-why require nonmember defendants to exhaust remedies in courts that do not presumptively have jurisdiction over them in the first place? The dissenting approach in the Eighth Circuit

266. See id at 444 n.3.

267. See A-1 Contractors v. Strate, 76 F.3d 930, 934-35 (8th Cir. 1996).

268. See id. at 936.

269. See id. at $935-36$.

270. See id. at 946 (McMillian, J., dissenting).

271. See id. at 947 . 
faced the opposite problem-if tribal courts presumptively have wideranging jurisdiction over nonmember civil defendants, how can tribal regulatory power over nonmembers be invalid in the absence of a "Montana exception"? If a tribal court applied tribal law to a nonmember civil defendant, would that not be an exercise of tribal regulatory authority?

When the case reached the Supreme Court, something had to give, and it was not surprising what it was. ${ }^{272}$ Justice Ginsburg's unanimous opinion in Strate generally followed the path of the majority of the Eighth Circuit, treating Montana as the controlling precedent concerning tribal-court civil authority over nonmembers. ${ }^{273}$ Ginsburg called the exhaustion requirement of National Farmers a "prudential," not a jurisdictional, rule. ${ }^{274}$ The contrary language in Iowa Mutual was drained of life by limiting it to situations in which the tribe could claim regulatory authority over nonmembers under Montana. ${ }^{275}$ The opinion waffled on a critical point, however. To be sure, Ginsburg did not limit Montana to tribal regulatory authority over nonmember fee lands. She did, however, equate the highway right-of-way to such lands: As with the allotment process that created nonmember fee lands, the tribe had consented to the creation of the rightof-way and had been compensated for it, and the federal government had granted the right-of-way to the state free from any reservation of sovereign rights on behalf of the tribe. ${ }^{276}$ Thus, Strate leaves open a variety of questions about tribal-court jurisdiction and exhaustion of tribal-court remedies concerning nonmember defendants where the cause of action arises on a reservation site other than nonmember fee lands, state or federal roads, or similar areas in which the federal government has explicitly divested the tribe of property rights and the power to exclude nonmembers. ${ }^{277}$

272. For a thorough doctrinal analysis suggesting that the Court should have overcome its instincts to protect nonmembers and recognized tribal adjudicative authority broader than tribal regulatory power, see Laurie Reynolds, "Jurisdiction" in Federal Indian Law: Confusion. Contradiction, and Supreme Court Precedent, 27 N.M. L. REv. 359 (1997).

273. See Strate, 520 U.S. at 445.

274. Id. at 453.

275. See id.

276. See id. at 454-55.

277. Strate also surely leaves open the question whether a tribal court may exercisc jurisdiction over a civil case involving a member plaintiff and a nonmember defendant. See id. at 441 (narrowly defining the question in the case as one concerning tribal-court jurisdiction over a civil suit arising out of an auto accident on a state highway between two nonmembers). But see Wilson v. Marchington, 127 F.3d 805, 813-14 (9th Cir. 1997), cert. denied, 118 S. Ct. 1516 (1998) (holding that a tribal court lacked jurisdiction over a case brought by a member against a nonmember).

In its most recent decision, El Paso Natural Gas Co. v. Neztsosie, 119 S. Ct. 1430 (1999), the Court continued its trend of depriving a tribal court of civil jurisdiction, but this time in a much narrower setting than that in Strate. The case involved claims of injury resulting from uranium mining operations. As the Court explained, in the Price-Anderson Act, 42 U.S.C. \$ 2014 (1994), Congress expressed a clear preference that federal district courts resolve certain liability claims related to the operations of the nuclear industry. Although Congress never expressly 


\section{G. Conclusion}

Whatever might be its ultimate reach, Strate continued a theme recognized in Bourland (the Court's most recent civil regulatory case) and Yankton (the Court's most recent reservation-diminishment case): When Congress opened a reservation area to nonmember entry, that action had the legal effect of presumptively immunizing nonmembers from tribal authority. Regardless of how the opinions read, it no longer really matters much how the statutory text reads. No longer is there a search for congressional intent clearly preempting tribal power over nonmembers. The reason that none of this matters is that the driving force in these cases is not whether Congress has clearly divested tribes of sovereignty. It is now sufficient that Congress intruded upon tribal sovereignty in ways that, the current Court concludes, are inconsistent with tribal authority in light of the practical circumstances and settled expectations of nonmembers.

It seems beyond question that, notwithstanding the plenary power of Congress over Indian affairs and despite the canons of interpretation that supposedly resolve open questions in favor of the tribes unless Congress has spoken clearly to the contrary, the Court has accorded itself front-line responsibility to handle current controversies in federal Indian law rather than simply to freeze the legal status quo and await definitive congressional resolution. What seems in significant doubt is how the Court's approach to the field can be rendered explicable. On their own terms, the opinions congeal into an incoherent muddle. Yet perhaps there are unarticulated or only vaguely identified values that can lend some explanatory light to this murky area. It is to this search for lurking factors that the next Part turns.

preempted tribal-court jurisdiction over such claims, the federal policy favoring a federal forum is much clearer than that involving diversity jurisdiction and routine tort cases applied by analogy in Strate. Neztsosie also contains language reading Strate quite narrowly:

[Petitioners argue] that the Tribal Courts somehow lacked jurisdiction over Price-

Anderson claims because under [Strate] a tribal court has jurisdiction over a nonmember only where the tribe has regulatory jurisdiction with respect to the matter at issue, and Congress has completely occupied the field of nuclear regulation. But Strate dealt with claims against nonmembers arising on state highways, and "express[ed] no view on the governing law or proper forum when an accident occurs on a tribal road within a reservation." By contrast, the events in question here occurred on tribal lands. Neztsosie, 119 S. Ct at 1436 n.4 (citations omitted). 


\section{DOING What COMES NATURALlY: METHODOLOGICAL RECONCEPTUALIZATIONS OF THE COURT'S OPINIONS CONCERNING TRIBAL AUTHORITY OVER NONMEMBERS}

\section{A. Judicial Lawmaking in the Guise of Routine Statutory Interpretation}

The most obvious methodological point about contemporary federal Indian law is that, in the absence of targeted congressional guidance, the Supreme Court stands ready to protect arguably significant nonmember interests rather than to wait for Congress to address the problem. It does not seem to make much difference whether, as in Oliphant, the Court acknowledges that no authoritative text controls and that the Court is engaged in federal common-lawmaking that divests tribes of inherent sovereignty or whether, as in Yankton, the Court purports to rely upon statutory or treaty text to diminish tribal interests. In both scenarios, the Court reaches whatever result seems most practical in the current context. The Court has, in effect, embraced a common law for our age of colonialism.

A striking evolution in judicial methodology has occurred in order to free the Court to pursue this mission. The canons of interpretation that once seemed to influence strongly, if not control, outcomes in federal Indian law cases $^{278}$ have lost their force in the context of significant nonmember interests. ${ }^{279}$ Yankton is only the most illuminating example of a process of gradual degradation of the canons. ${ }^{280}$ Even six years ago, it seemed possible to imagine a revival of the canons as a practical judicial strategy to force the Court to maintain the status quo and thereby require Congress to do the ugly work of implementing the ongoing processes of colonization. ${ }^{281}$ It is not too late to return to these conceptions of the appropriate judicial role, ${ }^{282}$ but that would require a judicial appreciation for the historical and contemporary value of the canons, ${ }^{283}$ an attitudinal shift that seems unlikely to occur.

This unraveling of the canonical approach is profoundly important. Quite often, the essential argumentative move in a statutory interpretation case is finding a way in which textual silence works in your favor. Canons of clear statement provide advocates with an excellent way of achieving this argument-structuring and outcome-producing result. Advocates for tribes have used this technique for years, contending that, under the Indian

278. See Wilkinson \& Volkman, supra note 30, at 617-20.

279. See Getches, supra note 22 , at 1620-22.

280. See Frickey, supra note 22, at 418-26.

281. See id. at $437-39$.

282. For a recent proposal, see Getches, supra note 22, at 1654-55.

283. For an attempt to make this case, see Frickey, supra note 22, at 406-40. 
law canons, silent or ambiguous statutory or treaty text must be interpreted in favor of tribal interests, preserving the status quo and forcing opponents of tribal interests to bear the burden of legislative inertia and persuade Congress to override tribal interests expressly. ${ }^{284}$ If, as Parts III and IV suggest, those canons have lost their force in federal Indian law where significant nonmember interests are at stake, the entire structure of dialogue in the field has shifted, and along with it the key institutional responsibilities.

In place of the canonical method, where only clear treaty or statutory text or congressional intent may displace tribal interests, the Court in such recent cases as Yankton, Strate, and Bourland took a more abstract interpretive approach, under which general congressional purposes control if they have worked their way sufficiently into the adjudicatory context. During the oral argument in Strate, a Justice said that nonmembers who stay on the good roads should be all right. ${ }^{2.55}$ As both civil regulatory precedents-Montana, Brendale, and Bourland, involving tribal power to regulate nonmembers on non-Indian reservation lands-and diminishment cases-Yankton and Hagen, involving reservation areas with largely nonIndian demographics-suggest, the same point could be made about nonmembers who find themselves in other "non-Indian" reservation areas.

Indeed, because there is always some text lurking in the background somewhere-some treaty, some federal statute of potential relevance-this new-found judicial freedom in interpretation seems to be merging with the Court's longer-standing approach to the common-law aspects of federal Indian law. For example, Oliphant, a case in which the Court did not conceive of itself as interpreting authoritative text at all, might be profitably reconceptualized. In light of just how loose "statutory interpretation" has become in federal Indian law, it would not be difficult to redraft the Oliphant opinion so that its rationale is one of statutory interpretation rather than federal common-lawmaking. Using Bourland as a guide, the revised opinion could conclude that the allotment statute in question, by opening the reservation to nonmember fee owners, abrogating the tribal power to exclude nonmembers, and resulting in a reservation overwhelmingly nonIndian today, destroyed tribal territorial criminal jurisdiction. This "interpretation" of the allotment statute would be as consistent with the general congressional purposes associated with allotment as the treaty or

284. See, e.g., Bryan v. Itasca County, 426 U.S. 373 (1976); see also Frickey, supra note 22. at $429-32$ (discussing Bryan).

285. "Just stay on the good roads; you've got nothing to worry about. Stay on the state highways." United States Supreme Court Official Transcript. Strate v. A-1 Contractors, 520 U.S. 438 (1997) (No. 95-1872), available in 1997 WL 10398, at *43; see also Phillip Allen White, Comment, The Tribal Exhaustion Doctrine: "Just Stay on the Good Roads, and You've Got Nothing to Worry About," 22 AM. INDLAN L. REV. 65, $65 \mathrm{n}{ }^{*}$ (1997) (attributing the comment to Justice Scalia). 
statutory interpretations in Yankton, Bourland, and Strate are consistent with general congressional purposes at work in those cases. If the seemingly bulletproof savings clause in Yankton is not enough to produce a contrary conclusion, then statutory or treaty silence on the key questionsas in Oliphant, Bourland, and Strate-should be no barrier at all. Ironically, an advantage of this rewriting of Oliphant from the tribal perspective is that it would not apply to unallotted reservations, such as the Navajo, where the area retains a solid "Indian character."

The apparent merger of statutory interpretation and commonlawmaking in these cases is highlighted by the role played by developments subsequent to the allotment of the reservation. In the reservationdiminishment cases, the Court has admitted that, in "interpreting" the allotment agreement or statute in question, it takes into account postenactment factors such as contemporary demographics and jurisdictional patterns that have arisen over time. ${ }^{286}$ This approach makes no sense if the interpretive touchstone of the agreement or statute in question is plain textual meaning (there is none), specific congressional intent about reservation boundaries (there is none), or original general congressional purposes (which are always assimilative, such that adhering to them would require that the tribes always lose, which they have not). This approach does become understandable, however, if we conceptualize the judicial role in these cases to be achieving a common-law-like resolution of a current dispute based on current context. ${ }^{27}$

At first glance, the Court's sensitivity to current context might seem to be a pragmatic interpretive effort defensible under William Eskridge's theory of "dynamic statutory interpretation." 288 To be sure, Eskridge has demonstrated both a positive case for dynamic interpretation-that judicial understandings of statutory meaning have sometimes evolved in light of changed circumstances unforeseen by the enacting legislature ${ }^{289}$-and a normative case as well-that such interpretation is sometimes consistent

286. See supra text accompanying notes $92-106,112-113,116-118,126$.

287. In the two principal inherent-sovereignty cases that still constitute victories for tribal sovereignty, Williams and Merrion, the reservations in question had never been allotted. Oliphant. the first modern case concluding that tribal sovereignty was inconsistent with domestic dependent nation status, involved a reservation that had been essentially destroyed by allotment. Once Oliphant decided that tribes lack inherent sovereignty to exercise criminal jurisdiction over nonIndians, however, it became irresistible in Duro to extend that rationale to protect nonmember Indians as well, even though the reservation in Duro had never been allotted. Perhaps in light of this fact, the Court in Duro did note the tribe's general power to exclude nonmembers, see Duro v. Reina, 495 U.S. 676, 696 (1990), which does not apply to nonmember fee owners on allotted reservations, see Brendale v. Confederated Tribes of Yakima Indian Nation, 492 U.S. 408, 422 (1989) (opinion of White, J.); id. at 436 (opinion of Stevens, J.). The Duro Court did not reach the question whether a tribe could condition permission to enter the reservation upon agreement to be subject to tribal authority. See Duro, 495 U.S. at 689; supra note 249.

288. See generally ESKRIDGE, supra note 129.

289. See id. at 9-105. 
with fundamental liberal, legal-process, and more openly normativist theories. ${ }^{290}$ For both descriptive and normative reasons, however, the Court's interpretive approach to federal Indian law is hard to defend within this framework.

First, the contrast between what the Court says controls-when, as in Yankton, it pretends that it is simply deferring to clear congressional inten ${ }^{291}$ - and the postenactment factors that actually are outcomedeterminative in these cases destroys all candor, an essential element for the assessment of dynamic interpretation. I would join Eskridge ${ }^{292}$ in asserting that the most defensible understanding of statutory interpretation, both positively and normatively, is a kind of critical pragmatism: one that attempts to construct practical outcomes in specific cases that resonate with the "complex web of social and legal practices" 293 found in the legal interpretive community while, simultaneously, critically reevaluating the elements of the web rather than simply deferring to the conventional wisdom. ${ }^{294}$ If the Court were to admit forthrightly that it was engaged in a similar enterprise in the diminishment cases, it would first be compelled to identify the values actually at work-primarily, the protection of the supposed reliance interests of non-Indians. It would then be required to consider the complex interpretive questions surrounding those interests, which would entail admitting that statutory text provides no guidance, that no original congressional intent on reservation borders existed, that the original congressional purposes of assimilation are obsolete, and that current federal policy favors tribal sovereignty. ${ }^{295}$ The Court would next be required to admit that changed circumstances have radically overthrown the allotment regime, leaving both tribes and non-Indians in disarray. The critical aspect of this kind of pragmatism would question whether Holmes's aphorism about "the prejudices judges share with their fellow [citizens]" provides a better explanation than any legalistic theory for the Court's privileging of the reliance interests of non-Indians over the interests of the tribes in preserving the remnants of reservations fractured by Congress's broken treaty promises. ${ }^{296}$

290. See id. at 107-204.

291. See supra note 130 and accompanying text.

292. And I have, more or less, in Eskridge \& Frickey, supra note 127. as well as in WILLAM N. ESKRIDGE, JR. \& PHIIP P. FRICKEY, CASES AND MATERIALS ON LEgISLATION: STATUTES AND THE CREATION OF PUBLIC POLICY (2d ed. 1995).

293. ESKRIDGE, supra note 129, at 201.

294. See id. at 199-204.

295. These factors track the elements of a diagram for pragmatic statutory interpretation that

Eskridge and I developed in Eskridge \& Frickey, supra note 127, at 345-62.

296. A journalist recently made the point this way:

The Lakotas were the victims of nineteenth-century social engineering that decimated their reservation. But the adventurous emigrants from Oslo and Odessa were also the victims of a terrible historical prank, the trick of the disappearing and now magically reappearing reservation. Their grandchildren are today discovering themselves in a 
Any suggestion that the Court has failed to appreciate the dynamic quality of its Indian law seems easily pushed aside by the startling contrast between two pronouncements of Justice Scalia. In his recently published Tanner Lectures, after first criticizing judicial reliance upon "unexpressed legislative intent" as "nothing but an invitation to judicial lawmaking," 297 Justice Scalia noted that "[t]here are more sophisticated routes to judicial lawmaking than reliance upon unexpressed legislative intent, but they will not often be found in judicial opinions because they are too obvious a usurpation." ${ }^{298} \mathrm{He}$ then referred to Eskridge's theory of dynamic statutory interpretation as a "modern and forthright approach to according courts the power to revise statutes" ${ }^{299}$ so that " $[t]$ he law means what it ought to mean." 300

Compare these comments to a remarkable memorandum found in the papers of Justice Marshall. It turns out that in Duro, Justice Scalia was

strange new political world that was not of their making, hungry for protection and obliged to learn the new and difficult language of tribal power. It is a rhetoric that, reasonably enough, demands for tribes a degree of self-government that is taken for granted by other Americans; it also asks non-Indians to live under tribal taxation, police, and courts of sometimes dubious reliability.

BORDEWICH, supra note 6 , at 328 . Contrast the views of a legal scholar:

No treaty promises were made to non-Indian settlers in the Indian country. At most, the federal government invited non-Indians into the Indian country with the understanding that eventually the Indians would assimilate and the tribes would disappear. That expectation may have created a form of psychological reliance, but it should have created no legal reliance interests....

But if the federal government made no promises to non-Indian settlers that could have ripened into vested rights, the government most assuredly did make those promises to the tribes [in treaties that were subsequently unilaterally abrogated through allotment].

Royster, supra note 68, at 71-72. Royster found no logic in the argument "that the government should now keep its 'promise' to the settlers, but not its promise to the tribes." Id. at 72 .

For the reasons briefly sketched infra note 369 , I would side with Royster, despite having more sympathy for the non-Indian position than she articulates, rather than with Bordewich, who may be guilty of overvaluing "melting pot" notions of social homogeneity. See BORDEWICH. supra note 6, at 329 (implausibly suggesting that retaining tribal sovereignty amounts to "legitimizing segregation for Indians[, which] will set a precedent for its potential imposition upon black, Asian, and Hispanic Americans"). Whichever way one comes out. however, it is striking that the Court has never engaged in anything approaching this sort of candid acknowledgment of the important factors.

297. ANTONIN SCALia, A MATTER OF INTERPRETATION: FEDERAL COURTS AND THE LAW 21 (1997). Lest I be accused of Scalia-bashing in the discussion that follows in the text, allow me to note my concurrence in Eskridge's critical but respectful review of this book. See William N. Eskridge, Jr., Textualism, The Unknown Ideal?, 96 MICH. L. REv. 1509 (1998). Justice Scalia's willingness to engage in candid theoretical and practical debate about statutory interpretation has been the single greatest blast of fresh air in a field that had long lain dormant to considered intellectual reevaluation. See Philip P. Frickey, Revisiting the Revival of Theory in Staturory Interpretation: A Lecture in Honor of Irving Younger, 84 MINN. L. REV. (forthcoming 1999) (assessing Justice Scalia's impact upon statutory interpretation).

298. SCALIA, supra note 297, at 21 (discussing the theory of judicial statutory revision in light of common-law evolution proposed in GUIDO CALABRESI, A COMMON LAW FOR THE AGE OF STATUTES (1982)).

299. Id. at 22 .

300. $I d$. 
inclined to join Justices Brennan and Marshall in dissenting from the majority's rejection of tribal-court criminal jurisdiction over nonmember Indians. Upon examining recent precedents with an eye toward writing the dissent that Brennan had assigned to him, however, Scalia changed his mind. He explained his reasoning to Brennan:

[O]ur opinions in this field have not posited an original state of affairs that can subsequently be altered only by explicit legislation, but have rather sought to discern what the current state of affairs ought to be by taking into account all legislation, and the congressional "expectations" that it reflects, down to the present day. ${ }^{301}$

Justice Scalia has several things exactly right. As his memorandum recognizes, the opinions in federal Indian law represent dynamic interpretation to the core. As he stated in his Tanner Lectures, presumably the opinions fail to acknowledge the dynamism because, in the eyes of many, it would be "too obvious a usurpation."

How could Justice Scalia embrace in federal Indian law precisely the sort of judicial revisionary power he later condemned in these lectures? In his memorandum to Justice Brennan, he explained that "I would not have taken that approach as an original matter, but it seems too deeply imbedded in our jurisprudence to be changed at this stage." ${ }^{302}$ Of course, he has not wavered in his attacks upon other "deeply imbedded" notions inconsistent with his jurisprudence, such as evolutive constitutional interpretation ${ }^{303}$ and the use of legislative history in statutory interpretation. ${ }^{304}$ It seems inescapable that the reason is that federal Indian law is not worth the bother. ${ }^{305}$ But at least Scalia deserves credit for understanding the conflict between his jurisprudential scheme and the interpretive practices of his colleagues and for initially voting for the former despite the siren call, so alluring to other Justices, of protecting non-Indian interests.

301. Memorandum from Justice Antonin Scalia to Justice William J. Brennan. Jr. Regarding Duro v. Reina (Apr. 4, 1990) (available in The Papers of Thurgood Marshall. Library of Congress) (emphasis added). David Getches uncovered this memorandum and discussed it in Getches, supra note 22, at 1575. I thank him for a copy of it.

302. Memorandum from Justice Scalia to Justice Brennan, supra note 301.

303. See, e.g., United States v. Virginia, 518 U.S. S15, 567 (1996) (Scalia. J., dissenting) ("[T]his most illiberal Court ... has embarked on a course of inscribing one after another of the current preferences of the society ... into our Basic Law.").

304. See, e.g., Bank One Chicago v. Midwest Bank \& Trust Co., 516 U.S. 264. 279 (1996) (Scalia, J., concurring in part and in the judgment). For remarkable examples, sec Lexecon, Inc. v. Milberg, Weiss, Bershad, Hynes \& Lerach, 523 U.S. 26, 28 n.† (1998) (noting that Justice Scalia refused to join the portion of the opinion stating why the other Justices rejected a legislativehistory argument); and Associates Commercial Corp. v. Rash, 520 U.S. 953, 955 n." (1997) (same).

305. Cf. Frickey, supra note 22, at 383 (noting reported remarks from Justices about how federal Indian law disputes are "peewee" cases, even "chickenshit cases"). 
If the Court's dynamism cannot be excused on the ground that it has been inadvertent, it can only be defended on the basis of the values that it promotes. At bottom, federal Indian law cases involving potential tribal authority over nonmembers pose a stark conflict among liberal values of personal autonomy and private property (protecting nonmember reliance interests; protecting that measure of inherent authority and territory of tribes that has not heretofore been involuntarily displaced by the colonial process) and among more communal values as well (the cross-cutting communal notions of nonmembers and members; the dilemma of creating a constitutional order based on social-contract theory through a colonial process displacing indigenous peoples). The Court's choices of values to be privileged fly in the face of institutional values-an established canonical interpretive regime dating back to the Marshall Court, which would require Congress, not the Court, to take express action before further diminishment of Indian interests is given legally cognizable effect. The Court has failed to acknowledge its remarkable dynamism, much less to include any critical element in it by testing whether the values that it privileges can withstand normative reassessment under the sort of "play of intelligence" that my colleague Daniel Farber has noted is the hallmark of balanced pragmatic legal analysis. ${ }^{306}$ For even if, as Eskridge suggests, critical dynamism in the pursuit of virtue is no vice, uncritical dynamism in the pursuit of the visceral is no virtue.

\section{B. Bringing the Constitution to Indian Country}

Of course, postenactment factors can involve legal as well as contextual evolution. In the more overtly common-law mode it used in Oliphant and Duro, the Court acknowledged that it was attempting to harmonize the legal as well as the contextual landscape. Oliphant stressed the expanding protections of civil liberties over time ${ }^{307}$ and the felt necessity of protecting "outsiders" against criminal prosecution by narrow entities that have

306. See Daniel Farber, Missing the "Play of Intelligence," 36 WM. \& MARY L. REV. 147 (1994). Farber, in tum, relied upon the advice of our late colleague, Irving Younger, conceming effective legal writing:

You must see through and around your subject, measuring it by more than one measuring stick, turning it over, testing it, arriving at a just and clear-headed assessment of its position in the hierarchy of things.

The word that best expresses this requisite distance is "detachment," understood as a certain amusement with the enterprise upon which you are engaged, a sense of humor about yourself and your works. If a lawyer has it, the lawyer's writing will unfailingly communicate the play of intelligence ("play" here being as important as "intelligence").

Id. at 166 (quoting Irving Younger, Let's Get Serious, A.B.A. J.. May 1, 1987, at 110).

307. See supra note 210. 
unique laws and uncommon procedures ${ }^{308}$ Duro emphasized that, since 1924, Native Americans have been citizens of the United States and presumably deserve the same protections of individual liberty generally available against governmental power and specifically extended to nonIndians as against tribal criminal authority in Oliphant. ${ }^{309}$ Indeed, Duro's citation to Reid v. Covert ${ }^{310}$ was a dramatic reference to evolving constitutional law that applies the Constitution to novel and narrowly defined governmental institutions.

In my judgment, what the Court has done-without any conscious reflection in its opinions-is to use federal common law to "quasiconstitutionalize" ${ }^{311}$ the relationship between tribes and nonmembers. This explains why the Court can pick and choose between members and nonmembers with respect to immunity from tribal regulation, rather than impose uniform limitations upon tribal action benefiting members and nonmembers alike.

It is obvious that the Court has found it increasingly incongruous that tribes, as entities within the borders of the United States subject to ultimate congressional control, may use the coercive power of government against nonmembers without being subject to all of the basic constitutional limitations and remedies. This incongruity has been heightened because in most of the cases the tribe has struggled to regulate such persons in circumstances in which Congress long ago destroyed the tribe's ability to exclude nonmembers and in which the region in question may have, to Anglo judicial eyes, lost its "Indian character." At least in such surroundings, tribal sovereignty might appear to be one of Holmes's accidental relics of history, and judicial intervention to protect nonmembers might seem to be required as an appropriate felt necessity in a society based on the fundamental rule of law encapsulated in constitutional values.

To be sure, the Indian Civil Rights Act does limit tribal authority over all persons, including nonmembers. But, as Oliphant and Duro stressed, ${ }^{312}$ the statute falls short of imposing all basic constitutional protections and remedies upon tribes, and tribes retain the authority to use all-member juries. As Duro indicated, a tribal member has the protection associated

308. See supra note 182.

309. See Duro v. Reina, 495 U.S. 676, 692-96 (1990).

310. See supra text accompanying notes 203-213.

311. By this I mean that the Courn is implementing constitutional values not by imposing the Constitution directly upon the tribes, but instead by treating those values as premises for federal common-lawmaking. The Court has used a similar technique in implementing the values of separation of powers and federalism indirectly, through clear-statement rules of statutory interpretation that cabin congressional intrusions upon these values. rather than by invalidating federal legislation as unconstitutional. See William N. Eskridge, Jr. \& Philip P. Frickey, QuasiConstitutional Law: Clear Statement Rules as Constitutional Lawmaking. 45 VAND. L. REV. 593 (1992).

312. See supra note 182 and text accompanying notes 208-209. 
with the right to vote in tribal elections and in any event may, by consent, buy into this scheme, but nonmembers without voting rights may have no apparent nonjudicial protections available. ${ }^{313}$

The Court's difficulty in harmonizing basic American values with tribal power is reminiscent of its struggles to expand the scope of the Constitution in other areas. It seems similar in impulse to the incorporation doctrine, whereby the Court, without any firm constitutional textual or historical hook, applied the most important provisions of the Bill of Rights to the states by way of the Due Process Clause of the Fourteenth Amendment. ${ }^{314}$ An even more striking example is the "reverse incorporation" doctrine arising from Bolling v. Sharpe, ${ }^{315}$ in which the Court concluded that the Fifth Amendment's Due Process Clause contains an implied equal protection limitation against federal action. In both incorporation and reverse incorporation, the Court essentially took it upon itself to complete an incomplete Constitution, one that did not clearly establish a baseline of nationally uniform protections against state governments and that failed expressly to limit federal action classifying persons on sensitive personal criteria such as race. Similarly, as Duro recognized by citing Reid v. Covert, the Court has struggled with whether the Constitution applies to federal action in foreign domains and to narrow institutions with unique authority over their members, such as the military (and now tribes).

Much in the pattern of federal Indian law precedents is analogous to these developments. Perhaps the most obvious is the implicit methodology of balancing. The incorporation doctrine began by imposing upon the states only those values "implicit in the concept of ordered liberty." 316 Similarly, when confronted with the question whether the Constitution "follows the flag" and applies outside the borders of the United States, the Court initially concluded that in unincorporated territories only fundamental protections of the Constitution attached to limit congressional power.$^{317}$ The Indian law cases have used a similar weighing process to conclude that tribal authority vis-à-vis nonmembers is prohibited for criminal jurisdiction,

313. See supra text accompanying notes $200-201$.

314. On the incorporation doctrine, see, for example, Jerold H. Israel, Selective Incorporation Revisited, 71 GEO. L.J. 253 (1982).

315. 347 U.S. 497 (1954).

316. Palko v. Connecticut, 302 U.S. 319,325 (1937). The standard has evolved such that today the question is whether the right is "fundamental to the American scheme of justice." Duncan v. Louisiana, 391 U.S. 145, 149 (1968).

317. See Downes v. Bidwell, 182 U.S. 244 (1901). For a helpful overview, see NeUMaN, supra note 204, at 4-5, 85-89. Although Downes and the other Insular Cases have never been overruled, their precedential value was undercut by Reid v. Covert, the case cited in Duro, see supra text accompanying notes 203-213, as suggesting limits even upon congressional authorization of tribal criminal jurisdiction over nonmembers. On the effect of Reid on the Insular Cases, see NEUMAN, supra note 204, at 5, 89-94, 101, 106. 
authorized for taxation, invalid for civil regulation except in specified circumstances, and unsettled for judicial jurisdiction in civil cases.

Other aspects of the federal Indian law cases do not fit the broader pattern of public-law evolution, however. The Court has never questioned Talton v. Mayes, which for a century has stood for the proposition that tribal action is not subject to the Constitution. ${ }^{318}$ Moreover, Oliphant and Duro do not impose limits upon a tribe's regulation of its own members. ${ }^{319}$ In contrast, the incorporation doctrine protects both state residents and outof-staters from abuses of state authority.

It also seems clear that the Court has retained the option of deferring to any responsive congressional action that disagrees with its precedents protecting nonmembers. Indeed, it expressly stated in Oliphant that Congress could authorize tribes to exercise criminal jurisdiction over nonIndians. ${ }^{320}$ Thus, when Congress acted upon this suggestion by passing legislation overturning the result in Duro by recognizing inherent tribal authority to prosecute nonmember Indians, ${ }^{321}$ it acted within its authority to control the allocation of sovereignty in Indian country. ${ }^{322}$ In contrast, of

318. See supra text accompanying notes 45-47, 208.

319. See Duro v. Reina, 495 U.S. 676, 693 (1990) ("The retained sovereignty of the tribe is but a recognition of certain additional authority the tribes maintain over Indians who consent to be tribal members.").

320. See Oliphant v. Suquamish Indian Tribe, 435 U.S. 191, 210 (1978) (“ By submitting to the overriding sovereignty of the United States. Indian tribes therefore necessarily give up their power to try non-Indian citizens of the United States except in a manner acceptable to Congress."); id. at 212 (stating that various policy considerations arguably supporting tribal criminal jurisdiction over non-Indians are "for Congress to weigh in deciding whether lndian tribes should finally be authorized to try non-Indians").

321. In 1990, Congress authorized tribal courts to exercise criminal jurisdiction over nonmember Indians for a one-year period. It did so by amending the Indian Civil Rights Act, 25 U.S.C. § 1301(2), changing the definition of "powers of self-government" to mean: "the inherent power of Indian tribes, hereby recognized and affirmed, to exercise criminal jurisdiction over all Indians." Act of Nov, 5, 1990, Pub. L. No. 101-511, § 8077(b), 104 Stat. 1856, 1892. This approach was made permanent in 1991. See Act of Oct. 28. 1991, Pub. L. No. 102-137, 105 Stat. 646.

322. Despite Duro's reference to Reid v. Covert, see supra text accompanying notes 203-213, I am unaware of any court that has struck down the "Duro fix" as beyond congressional power. Cf. Means v. Northern Cheyenne Tribal Court, 154 F.3d 941, 946 n.7 (9th Cir. 1998) (noting this concem). For contrasting commentaries on the constitutionality and appropriateness of the Duro fix, see Gould, supra note 73; Nell Jessup Newton, Permanent Legislarion to Correct Duro v. Reina, 17 AM. INDIAN L. REv. 109 (1992); and Alex Tallchief Skibine, Duro v. Reina and the Legislation that Overturned It: A Power Play of Constiturional Dimensions, 66 S. CAL L. REV. 767 (1993).

A recent Eighth Circuit panel decision seriously misunderstood the source of the tribal power exercised when a nonmember Indian is prosecuted. In Unired States v. Weaselhead, 156 F.3d 818 (8th Cir. 1998), district court judgment reinstated by equally divided en banc count per curiam, 165 F.3d 1209 (8th Cir. 1999), petition for cert. filed. U.S. Apr. 29. 1999 (No. 98-9211). the district court had held that double jeopardy did not bar the federal prosecution of a nonmember Indian for a crime on a reservation for which he had already been tribally prosecuted. A majority of the Eighth Circuit panel disagreed. The panel reasoned that tribal criminal jurisdiction over nonmember Indians pursuant to the Duro fix resulted from delegated federal authority, not inherent tribal sovereignty, and thus the defendant had already been prosecuted once 
course, incorporation and reverse incorporation impose limits on state and federal power that cannot be overturned by mere legislation.

Accordingly, what the Court has done in Oliphant and its progeny is not perfectly analogous to the incorporation doctrine, the reverse incorporation doctrine, or cases such as Reid $v$. Covert. To be sure, these precedents capture much of the apparent judicial impetus to harmonize the constitutional landscape and complete an incomplete Constitution, but they are not alone on the list of constitutional doctrines that do so. In my judgment, a closer analogy lies with the dormant Commerce Clause doctrine. $^{323}$

At the outset, it is important to state the limits of this analogical effort. The Court has never even recognized that Oliphant and its progeny share some similarities with the dormant Commerce Clause approach, much less attempted to legitimate the former by reference to the latter. Moreover, as explained below, that approach would be a particularly inapt one to

by the same sovereign that sought to subject him to criminal penalty again. See id. at 824 . The panel recognized that in the Duro fix Congress intended to recognize inherent tribal authority rather than to delegate new federal authority. See id. at 823 . The panel concluded, however, that it was the judicial, not the congressional, role to establish the baseline of tribal sovereignty, and that any congressional modification of the baseline enhancing tribal authority amounted to a delegation of federal power. See id. at 824. In dissent, Judge Morris Amold understood that Oliphant and Duro were merely federal common-law decisions subject to congressional revision. See id. at 825 (M. Arnold, J., dissenting).

Judge Arnold was clearly correct, as a brief example should demonstrate. Suppose that the federal courts conclude that a state regulation of semitrailer truck length unduly burdens interstate commerce and declare the state law invalid under the dormant Commerce Clause doctrinewhich, although a constitutionally rooted rule, is actually best understood as an aspect of federal common law. See infra text accompanying notes 326-327. Then suppose that Congress enacts legislation authorizing states to regulate the length of such trucks. Surely when the state resumes truck-length regulation, it is exercising its inherent police power-which always existed, even though for a time it was preempted by federal common law-rather than some peculiar delegated federal authority. The effect of the congressional authorizing legislation was to destroy the preemptive barrier of federal common law-thereby allowing the always-existing-but-oncepreempted local police power to spring back free from judicial interference-not to delegate special federal power to the state.

This is the way that we understand federal preemption of the local police power. It should also be the way that we evaluate the Duro fix. Before European discovery of this continent, tribes had the local police power. The federal common-law decision in Duro preempted that police power over nonmember Indians; the Duro fix simply lifted the federal common-law preemption from the tribe's police power. The prosecution of nonmember Indians is now, and always has been, an exercise of inherent tribal authority-it was just that, for a time, this authority was preempted by federal common law. Accordingly, when the tribe first prosecutes a nonmember Indian and then the federal government prosecutes that defendant on the same set of facts, there is no double jeopardy problem because the prosecutions are accomplished by different sovereigns. Cf. United States v. Wheeler, 435 U.S. 313 (1978) (holding that tribal prosecution of a member is pursuant to inherent tribal authority, so that later prosecution by the United States for the same offense does not offend double jeopardy).

323. For discussions of the dormant Commerce Clause doctrine, see, for example, Lisa Heinzerling, The Commercial Constitution, 1995 SUP. CT. REV. 217; Michael A. Lawrence, Toward a More Coherent Dormant Commerce Clause: A Proposed Unitary Framework, 21 HARV. J.L. \& PuB. POL'Y 395 (1998); and Martin H. Redish \& Shane V. Nugent, The Dormant Commerce Clause and the Constitutional Balance of Federalism, 1987 DUKE L.J. 569. 
embrace in Indian law. These similarities in form but dissimilarities in substance suggest that the judicial impulse in Indian law is attributable more to an unreflective drift toward more familiar public-law techniques than to a careful attempt to justify doctrinal evolution by sound analogical reasoning or other defensible methods.

The dormant Commerce Clause cases are familiar terrain. As every constitutional law student learns, there is no constitutional text that prohibits states from burdening interstate commerce in ways that favor local interests. Of course, Congress has the authority, pursuant to the Commerce Clause, to outlaw such nationally counterproductive state regulation. But instead of understanding this grant of congressional power and this absence of any limitation upon state power as according Congress all front-line federal responsibility concerning free national markets, the Court has, for a century and a half, assumed its own role. ${ }^{324}$ It has viewed the delegation of authority to Congress to regulate interstate commerce as expressing such a firm constitutional policy favoring free national markets that a rebuttable presumption exists against allowing states to burden interstate commerce unduly even in the absence of congressional regulation. ${ }^{325}$

In light of the lack of constitutional textual support for these developments, the dormant Commerce Clause doctrine, like incorporation and reverse incorporation, amounts to judicial improvement of an incomplete Constitution. In essence, the Court has inferred, from a grant of congressional power, an implied, judicially enforceable limitation upon state power. Because this limitation is premised upon a presumption concerning congressional wishes rather than upon any constitutional provision or doctrine (such as incorporation) outlawing such state action, however, judicial decisions enforcing the doctrine have the quality of federal common law rather than constitutional law-they are merely suspensive vetoes of such implicitly preempted state acts, leaving it open to Congress to authorize the states to proceed again along the formerly judicially disapproved lines. ${ }^{326}$

In many respects, the dormant Commerce Clause methodology seems analogous to the implicit-divestiture approach of Oliphant and its progeny. Both use the suspensive-veto technique of preserving ultimate congressional responsibility over the subject matter. Moreover, the Indian law cases, like the dormant Commerce Clause cases, seem premised on an

324. See, e.g., Cooley v. Board of Wardens. 53 U.S. (12 How.) 298 (1851).

325. See Lawrence, supra note 323, at 411-12.

326. See, e.g., In re Rahrer, 140 U.S. 545 (1891); LAURENCE H. TRIBE AMERICAN CONSTITUTIONAL LAW $\S 6-2$, at 403-04 (2d ed. 1988) (noting that because the dormant Commerce Clause cases are "negative judicial inferences from a constitutional grant of power to Congress, the Supreme Court's doctrinal limitations on state interference are always subject to congressional revision"). 
assumed congressional intent surrounding a constitutional grant of congressional power. ${ }^{327}$

The only constitutional grant of power expressly concerning Indian affairs is the Indian Commerce Clause, providing that Congress may "regulate commerce... with the Indian Tribes." ${ }^{28}$ In light of the narrowness of this text, it is something of a legalistic mystery how Congress ended up with "plenary power" over Indian affairs. ${ }^{329}$ But despite the rejection of the notion in an earlier case, ${ }^{330}$ the Court has stated that "the central function of the Indian Commerce Clause is to provide Congress with plenary power to legislate in the field of Indian affairs." 331

Note the similarity between the judicially ascribed power of Congress over Indian affairs and that over interstate commerce: Both are "plenary." 332 Both fields also overlap with the local police power. The Supreme Court long ago abandoned the notion that, once an activity was considered to be in interstate commerce, state power over it was absolutely forbidden even in the absence of preempting federal statutes. ${ }^{333}$ Instead, the dormant Commerce Clause doctrine provides that, in the absence of federal preemption or approval, state regulation of interstate commerce is generally upheld unless it facially discriminates against interstate commerce, is motivated by protectionist purposes, or unduly burdens interstate commerce. ${ }^{334}$ The basic idea is that, although states often have legitimate interests in regulating matters connected to interstate commerce, state regulation nonetheless requires first-line federal judicial supervision because of the incentives that states have to favor local interests at the expense of outsiders in particular and of national commerce in general. ${ }^{35}$

327. Because Oliphant expressly stated that Congress could overturn its result by legislation, an occasional commentator has briefly noted the similarity between the suspensive veto adopted in that case and the Court's dormant Commerce Clause doctrines. See, e.g., Philip S. Deloria \& Nell Jessup Newton, The Criminal Jurisdiction of Tribal Courts over Non-Member Indians: An Examination of the Basic Framework of Inherent Tribal Sovereignty Before and After Duro v. Reina, 38 FED. B. NEwS \& J. 70, 74 (1991); Karl J. Kramer, Comment, The Most Dangerous Branch: An Institutional Approach to Understanding the Role of the Judiciary in American Indian Jurisdictional Determinations, 1986 WIS. L. REV. 989, 998-99.

328. U.S. CONST. art. I, $\S 8, \mathrm{cl} .3$.

329. See Frickey, supra note 23 , at $35-36$. As explained there, congressional plenary power is no mystery to the legal realist: Legislative power to conduct colonization is an essential attribute of any colonial society, and it is far more efficient to centralize that power in the Congress than to disperse it among the states. See id. at 52-74.

330. See United States v. Kagama, 118 U.S. 375, 378-79 (1886) (holding that the Indian Commerce Clause cannot justify federal legislation regulating noncommercial intratribal affairs).

331. Cotton Petroleum Corp. v. New Mexico, 490 U.S. 163, 192 (1989).

332. As to interstate commerce, this notion has solid judicial recognition all the way back to Gibbons v. Ogden, 22 U.S. (9 Wheat.) 1, 196-97 (1824).

333. See, e.g., Cooley v. Board of Wardens, 53 U.S. (12 How.) 298, 320 (1851).

334. This summary is similar to the "Unitary Framework" of Lawrence, supra note 323, at 416-17.

335. See, e.g., South Carolina State Highway Dep't v. Barnwell Bros., 303 U.S. 177. 184 n.2 (1938); TRIBE, supra note $326, \S 6-5$, at $409-10$. 
The judicially understood conception of the Interstate Commerce Clause is, thus, not simply a grant of "plenary" power to Congress over interstate commerce, but a constitutionally recognized and judicially cognizable policy favoring national free trade even in the absence of congressional action pursuant to the clause. The purpose is to protect outsiders against illegitimate local interference. The premise is that state boundary lines are in most instances irrelevant to rational regulation of presumptively free economic markets. If the Court guesses wrong about congressional wishes when it invalidates a particular state regulation of interstate commerce, Congress may of course enact legislation overturning the judicial resultthus perhaps allaying concerns about judicial activism expanding an express grant of congressional authority into an unwritten source of judicial power.

Similarly, although the plenary power doctrine in federal Indian law authorizes Congress to regulate even the most local of tribal affairs on the reservation, ${ }^{336}$ the backdrop of unexercised congressional power is not understood to preempt tribal authority automatically, for otherwise tribal sovereignty would have vanished completely. ${ }^{337}$ But at least since Oliphant, it has been clear that tribal authority may be preempted by judicially articulated federal policy even in the absence of any congressional exercise of its plenary power. Like the dormant Commerce Clause doctrine, this "dormant plenary power impulse" provides first-line, searching federal judicial scrutiny to evaluate whether tribes have legitimate local interests implemented by appropriate lawmaking and law-applying procedures and institutions that transcend the interests of outsiders to be free from tribal authority. The implicit assumption seems to be that the judicially constructed doctrine of congressional plenary power over Indian affairs not only accords Congress a police power in Indian country, but that it also represents a national policy that, in the absence of congressional action, there is a presumption that Indian reservation boundaries are irrelevant to rational, nondiscriminatory regulation of insiders and outsiders. Because this policy amounts to a presumption about unenacted congressional intent rather than a constitutional command, Congress may overturn federal judicial invalidation of tribal regulation of nonmembers, as it has done in rejecting Duro by enacting legislation authorizing tribes to exercise criminal jurisdiction over nonmember Indians.

336. See United States v. Kagama, 118 U.S. 375, 383-84 (1886) (upholding a federal statute prohibiting intratribal crimes). The Supreme Court has never invalidated federal legislation on the theory that it unduly invaded tribal affairs. See supra note 53 and accompanying text.

337. $C f$. United States v. Wheeler, 435 U.S. 313. 328-29 (1978) (holding that a tribe retains inherent sovereignty to prosecute a member even though Congress had also made the conduct a federal crime). 
The analogy to the dormant Commerce Clause doctrine thus illuminates what the Court has been doing unreflectively in the implicit-divestiture cases. The analogy fits Montana well, for there the Court struck down a facially discriminatory tribal rule forbidding only nonmembers from hunting or fishing throughout the reservation. It takes a bit more work to make sense of Oliphant and Duro, for there the tribe was only seeking to subject outsiders to the same tribal laws and institutions that applied to insiders. Apparently, the Court concluded that such facially even-handed regulation nonetheless unduly burdened nonmember interests. In the typical scenario involving facially neutral and generally applicable economic regulation, it is presumed that the interests of out-of-state entities burdened by the regulation are virtually represented in the state political process by similarly situated in-state regulated entities. ${ }^{338}$ In Oliphant and Duro, the Court apparently did not view nonmembers as similarly situated to members, in light of the unique tribal laws and institutions in place, especially the presence of an all-member jury. ${ }^{339}$

The dormant plenary power impulse is a striking example of judicial activism against the backdrop of wide-ranging congressional power. As with the judicial invasion of the local police power under the dormant Commerce Clause doctrine, the implication of judicially enforceable limits on tribal authority based solely upon a grant of congressional power over the subject matter is a kind of bootstrapping. But the dormant plenary power impulse in federal Indian law involves another, even more radical, kind of bootstrapping. At least the dormant Commerce Clause doctrine empowers federal courts to interfere with the police power of the states only concerning matters of economic regulation, a subject on which the Constitution expressly grants legislative authority to Congress when

338. See Mark Tushnet, Rethinking the Dormant Commerce Clause, 1979 WIS. L. REv. 125. $139-40$.

339. The other major precedents might also be explained as applications of the inquiry whether tribal regulation unduly burdens nonmembers who are not situated similarly to members. Merrion suggests that, when nonmembers have the capacity ex ante to negotiate with tribes, the federal courts should not supplement the bargain by adding common-law immunities to tribal authority. In contrast, where, as in Montana and Brendale, nonmember fee owners have no convenient way to negotiate ex ante with tribes, common-law immunities to tribal regulation may seem more appropriate. In addition, the power to tax at issue in Merrion, as it implicates the very capacity of a government to survive, may have been viewed as a stronger local justification for tribal authority than the power to regulate hunting and fishing (Montana) and to zone (Brendale) within the reservation.

The tribal-court civil jurisdiction cases remain somewhat inscrutable under this analysis. however. Perhaps the nonmember store owner in Williams could have protected himself ex ante. so that his failure to find some way to avoid tribal court for his collection actions required no judicial solicitude. National Farmers and Iowa Mutual may reflect a special judicial deference to other tribunals, but Strate indicates that this trend may have ended, at least for cases arising on nonmember land. The most recent decision, El Paso Natural Gas Co. v. Neztsosie, $119 \mathrm{~S}$. Ct. 1430 (1999), suggests that tribal courts retain presumptive civil jurisdiction over nonmembers on Indian land. See supra note 277. 
interstate concerns are present. Moreover, so long as state economic regulation is facially neutral and not motivated by self-serving purposes, a presumption of validity attaches to it. The dormant Commerce Clause doctrine is arguably consistent with the intentions of the constitutional Framers and does promote national free trade, a value around which there is almost uniform consensus. Contrast the dormant plenary power impulse. Even though the Court today understands congressional authority to be rooted in the Indian Commerce Clause, long ago the Court accorded Congress plenary power over all Indian affairs, commercial or otherwise. Because congressional power over Indian affairs is plenary, the front-line judicial power to invalidate tribal regulation lacks clearly defined limits as well. Moreover, the opinions do not aggregate into any presumption favoring the validity of tribal regulation of nonmembers so long as such regulation is facially neutral and seems free of improper motivation.

In establishing the plenary power of Congress over Indian affairs, the Court performed the perhaps disappointing, but nonetheless unsurprising, role of the "court of the conqueror" reflected in Johnson v. McIntosh: $:^{3+0}$ It deferred to established patterns and practices designed to centralize the colonial power in the political branches. When it, in effect, arrogated to itself what amounts to a judicially enforceable "dormant" aspect of this power, however, the Court became an actor imposing its own set of colonial values, not merely an agent of congressional choices. This second step seems remarkable, even given the realities of a colonial society. The Court has transformed itself from the court of the conqueror into the court as the conqueror.

\section{Harmonizing Federal Indian Law with the Anglo-American Legal Landscape}

The basic thrust of the Court's statutory interpretation and quasiconstitutional decisions in federal Indian law has been to domesticate tribal power by harmonizing federal Indian law with basic Anglo-American legal values and assumptions. The Court has produced a profound "flattening" of federal Indian law into the broader public law. The precedents and the canons of interpretation that have rendered the field of Indian law a unique exception to many general public-law principles have now been diluted in the name of legal uniformity and the protection of the perceived reasonable reliance of nonmembers upon their assumptions about the rule of law and the roles of lawmaking institutions within the United States.

This judicial missionary work of bringing the general law into Indian country may explain at least some of the Indian law precedents that are not

340. See supra note 188. 
simply rooted in statutory interpretation or quasi-constitutional elaboration. The clearest example is Strate. Recall that the case involved a suit brought in tribal court by a nonmember surviving spouse of a member decedent and by his member children against a nonmember concerning an auto accident on a state highway. These facts might seem analogous to the common situation in which a citizen brings suit in her home state's court against a citizen of another state. One of the most basic elements of civil procedure is that this scenario raises fears that the defendant will be unfamiliar with local processes or will be "hometowned" by the local judge or jury. Accordingly, in its wisdom, Congress enacted legislation allowing the outof-state defendant to remove the case to federal court. ${ }^{341}$ But, it would seem, the Court in Strate concluded that Congress lacked infinite wisdom, for it has never enacted legislation allowing nonmember defendants to remove cases from tribal court to federal or state court. Overtly analogizing to removal from state courts, ${ }^{342}$ the Court simply filled the gap in federal law by adopting a federal common-law approach precluding tribal-court authority on the facts of Strate, thereby compelling similarly situated plaintiffs, in the absence of diversity of citizenship and an amount in controversy authorizing federal jurisdiction, to bring the case in state court. $^{343}$

On the surface, Strate may seem defensible as similar to other decisions that borrow statutorily rooted policies to inform federal common-law evolution. Perhaps the most famous of these is Moragne v. States Marine Lines, ${ }^{344}$ in which the Supreme Court abandoned the common-law rule barring recovery for wrongful death in light of the repudiation of that approach in numerous federal and state wrongful death statutes. Few would quarrel with the general logic of Moragne that "legislative establishment of policy carries significance beyond the particular scope of each of the statutes involved. The policy thus established has become itself a part of our law, to be given its appropriate weight not only in matters of statutory construction but also in those of decisional law." 345 Now that federal Indian

341. See 28 U.S.C. $\S 1441$ (1994).

342. See Strate v. A-1 Contractors, 520 U.S. 438,459 n. 13 (1997).

343. The Court implicitly referred to forum-shopping concerns by noting that the protective action already filed by plaintiffs was in a state court that is "open to all who sustain injuries on North Dakota's highway," id. at 459, and that is "physically much closer by road to the accident scene ... than [is] the tribal courthouse," id. at 445 n.4 (quoting Brief for Respondents at 8 n.6).

344. 398 U.S. 375 (1970).

345. Id. at 390-91. On the theory that courts should reason by analogy from statutes that do not govern the litigative dispute but express a clear legislative policy strongly counseling the evolution of the common law, see James McCauley Landis, Statutes and the Sources of Law, in HARVARd Legal ESSAYS 213 (1934); Roscoe Pound, Common Law and Legislation, 21 HaRV. L. REV. 383 (1908); and Harlan F. Stone, The Common Law in the United States, 50 HARV. L. REV. 4 (1936). For an excellent student note on the theory that was written soon after Moragne. see Michael J. Bean, Note, The Legitimacy of Civil Law Reasoning in the Common Law: Justice Harlan's Contribution, 82 YALE L.J. 258 (1972). 
law is being folded into the general public law at an unprecedented rate, we might expect to see more Moragne-like reasoning importing principles from the "general law" ${ }^{346}$ in an effort to make the field less arcane-to domesticate it as a branch of general federal public law rather than to allow it to retain its complicated conglomeration of unique doctrines.

The potential consequences of this technique for federal Indian law would be hard to overstate. They easily transcend those of the Court's more established approaches-loose statutory interpretation and quasiconstitutional lawmaking-to accommodating nonmember interests. For, if broadly implemented, the Moragne technique could well mean the end of the field of federal Indian law as we have known it. This is so because, unlike loose statutory interpretation and quasi-constitutional lawmaking, which are at least both tied to presumptions about congressional purposes, moving Moragne into Indian law would suggest that the many aspects of federal Indian law that are in tension with general public-law principles should be judicially waved aside in the name of harmonization. Judges could then look to any source of general American legal principlesstatutes, administrative regulations, state as well as federal common lawand when, as will often be the case, an inconsistency appears, displace the established unique aspect of Indian law in the name of legal uniformity, all without any specific congressional guidance.

The Moragne method has influenced doctrinal evolution in such basic domains as torts and landlord-tenant relations, where certain aspects of the ubiquitous backdrop of the common law have been statutorily modified so consistently that it is clear that a more appropriate policy has been legislatively identified. ${ }^{347}$ Despite these important inroads, however, the method is probably generally unfamiliar to American-trained lawyers, who may assume that a statute can intrude into a common-law domain only when its terms govern the case. ${ }^{348}$ In my judgment, this traditional assumption does take a crabbed view of the capacity of legislatures to articulate reasoned principles counseling legal evolution. ${ }^{3+9}$ That the Moragne move is a legitimate tool for the reassessment of hoary doctrines in basic common-law fields in no way counsels the automatic use of the technique to flatten all unique legal regimes into more general patterns, however. Indeed, "[a] possible danger . . . is that the very unfamiliarity of the doctrine will give it an immediate superficial attractiveness. Initially

346. See Moragne, 398 U.S. at 391-92 (“Today we should be thinking of the death statutes as part of the general law." (quoting Roscoe Pound, Comment on State Death Starutes-Application to Death in Admiralty, 13 NACCA L.J. 188, 189 (1954))).

347. See Robert F. Williams, Statutes as Sources of Law Beyond Their Terms in CommonLaw Cases, 50 GEO. WASH. L. REV. 554, 571-73, 583 n. 160 (1982).

348. See id. at 557-58; Bean, supra note 345, at 258-59.

349. See ESKRIDGE \& FRICKEY, supra note 292, at 398-411 (examining case law and commentary on statutes as sources of law beyond their terms). 
grasped, the methodology seems capable of giving almost any solution desired for a particular problem." 350

In particular, where the courts have adopted special approaches to construct fine-tuned "interpretive regimes," ${ }^{351}$ there has been a judicial understanding that the legal domain in question has unique qualities legitimately distinguishing it from the "general law." An obvious example is criminal regulation: Statutory codes have displaced the common law of crimes, and those criminal statutes are construed narrowly so that the citizenry has fair notice of what conduct triggers sanctions. ${ }^{352}$ In such areas of law, special considerations counsel that doctrinal evolution generally requires direct legislative intervention, not common-law evolution.

Federal Indian law is best understood as one of these domains. It represents a structural, sovereign-to-sovereign arrangement that seeks to meld historical practices of colonization with a current commitment to tribal survival. Federal Indian law came first. It legitimated for non-Indian purposes the colonial processes used in the acquisition of Indian lands and the displacement and involuntary partial incorporation of indigenous peoples. It thereby made room-both literally and figuratively-for the construction of the general American legal system, which continues to sit awkwardly on top of internal tribal law and the federal-tribal relationship. Given this background and its contemporary consequences, an interpretive regime requiring clear congressional action to displace tribal prerogatives further draws force from precedent and principle alike. ${ }^{353}$ It follows that using the Moragne move to harmonize federal Indian law with the general American law would be judicial colonization of the first order. ${ }^{354}$

If increasing the clarity and predictability of federal Indian law is a prime impetus for this technique, it is also likely to be unavailing. ${ }^{355}$ For

350. Bean, supra note 345, at 279.

351. William Eskridge \& John Ferejohn, Politics, Interpretation. and the Rule of Law, in NOMOS XXXVI: THE RULE OF LAW 265, 267 (1994).

352. On the narrow construction of criminal statutes, see, for example, Dan M. Kahan, Lenity and Federal Common Law Crimes, 1994 SUP. CT. REV. 345.

353. Thus, federal Indian law involves more than the allocation of lawmaking power between the federal courts and Congress-the most fundamental question is whether either federal lawmaking entity has displaced underlying tribal authority. In this respect. Strate was a considerably more controversial exercise of the Moragne move than was Moragne itself, because there the Court may have been "influenced by the fact that it was dealing with an area of federal admiralty law, and not with an area in which the effect of a change would be to preempt otherwise applicable state law." David L. Shapiro, Continuity and Change in Statutory Interprefation, 67 N.Y.U. L. REV. 921, 953 (1992).

354. Cf. Frickey, supra note 11, at 1764-65 (criticizing scholarship suggesting that general equal protection theories should be imported into federal Indian law as making "an error of significant magnitude, for it confuses a puzzling, conceptually intractable, and little-understood comer of public law with its mainstream").

355. Indeed, even in the seemingly much simpler area of tort actions for wrongful death on the waters, the judicial implementation of Moragne has proved surprisingly difficult and controversial. See, e.g., Robert Force, The. Curse of Miles v. Apex Marine Corp.: The Mischief of 
example, in Brendale, Justice White, writing for a four-Justice bloc, argued that the tribe had no sovereign authority to zone nonmember reservation property, but did have a property interest in being free from usage of nonmember property that imperiled the tribal interest in using its own land as it reasonably saw fit. ${ }^{356}$ According to White, this federal property interest might be enforceable only through the county zoning process and whatever appeals or litigation might lie beyond it under state law. ${ }^{357}$ Then again, White seemed to indicate that the tribe might have a way to invoke federalcourt jurisdiction at some point to protect its property interest. ${ }^{358}$ In the final analysis, the opinion stands as an example of analogical reasoning in an endless loop, a descent into the maelstrom of judicial freewheeling that leads everywhere in general but nowhere in particular. The confusion and unpredictability are compounded by the fact that five Justices did not join the White opinion, with two of them opting for an outcome based on the Indian character of the area in question and three others arguing for the traditional notion that tribal sovereignty to zone should be territorial in scope. ${ }^{359}$ Brendale demonstrates that any judicial effort to undertake firstline responsibility for bringing coherence to federal Indian law by harmonizing it with the broader law may produce more, not less, of a conceptual mess. There are too many choices and not enough judicial consensus, even leaving aside the nagging question whether there is sufficient justification to overrule the many longstanding precedents recognizing unique tribal interests where Congress also has authority to displace such settled law.

As a final example, recall Duro. The Moragne technique suggests that a well-established statutory pattern of policy counsels reconsideration of an inconsistent common-law rule. Yet in Duro, the Court adopted a new constitutionally inspired common-law rule-that tribes had no criminal jurisdiction over nonmember Indians-in the face of a pattern of federal statutes suggesting that Congress had long assumed tribes had such jurisdiction and that, far from promoting a coherent harmonization of criminal jurisdiction in Indian country, produced a serious gap in it. ${ }^{360}$ The outcome in Duro starkly demonstrates that the three judicial techniques that have emerged in federal Indian law during the past two decades are not

Seeking "Uniformity" and "Legislative Inten" in Maritime Personal Injun Cases, 55 LA. L. REV. 745 (1995) (discussing cases following Moragne).

356. See Brendale v. Confederated Tribes \& Bands of the Yakima Nation. 492 U.S. 408, 430-

31 (1989) (White, J., joined by Rehnquist, C.J., and Scalia \& Kennedy. JJ.)

357. See id. at 431.

358. See id.

359. See supra text accompanying notes 222-230.

360. See supra note 211 (explaining the jurisdictional void concerning minor crimes committed by nonmember Indians against tribal members that resulted from Duro). 
always compatible. Taken together, these techniques may well promise more, not less, incoherence in federal Indian law.

\section{The Consequences of Doing What Comes Naturally: Anglocentric Analogical Reasoning}

Analogical reasoning is a key judicial tool. ${ }^{361}$ In an area as murky as federal Indian law, analogizing to more mainstream areas of law may be almost irresistible, especially for judges who have not developed any appreciation for why federal Indian law has grown up to be as unusual as it is. ${ }^{362}$ The Court's jurisprudence on tribal authority over nonmembers is saturated with analogical reasoning. Unfortunately, the Court's analogical exercises seem more ad hoc than adept, more Anglocentric than analytical.

In the diminishment cases, the Court seems to have jettisoned the canonical approach to the interpretation of statutes and treaties in favor of a fact-based analogical process. The basic inquiry is whether the reservation area in question is, in the Justices' minds, analogous to off-reservation areas. To put it bluntly, the Court seems to be asking, "is this area like the rest of South Dakota, or is it truly Indian in nature?" One might question the objectivity of this analysis from a group of jurists who may know little about South Dakota, much less about Indian reservations found there. Whatever vision is conjured up of a truly "Indian reservation" may have little to do with contemporary reality and imposes an essentialist, static conception upon the inherently dynamic institutions of tribal governance and contexts of tribal life.

In Oliphant and its progeny, the Court has embarked upon a process of bringing the values of the broader legal system to Indian country. The Constitution does not apply to tribal governmental action, and Congress has imposed only a qualified set of analogous limitations upon tribes in the Indian Civil Rights Act. Nonetheless, the Court has "improved" upon the congressional solution by diminishing tribal power when it threatens the judicial conception of fundamental rights untouched by ICRA, such as the threat that all-member juries might treat nonmembers unfairly. In these situations, the Court seems to view tribal processes as analogous to those of state and local governments, rather than as a different sort of sovereigntyone that predates the Constitution, possesses inherent, retained indigenous authority rather than constitutionally rooted reserved or delegated power,

361. See, e.g., Cass R. Sunstein, On Analogical Reasoning, 106 HARV. L. REV. 741 (1993).

362. Even scholars who are sympathetic to tribes have made this mistake, by explaining the canons of interpretation in federal Indian law as an application of a principle favoring discrete and insular racial minorities, when the appropriate justification for the canons is that they reflect the sovereign-sovereign relationship of tribes with the United States. See Frickey, supra note 22, at 424-26. 
and is subject to "Anglocization" (colonial assimilative impositions) through the congressional rather than the judicial process. Even more remarkably, Strate suggests that seemingly foundational subconstitutional values, such as the availability of removal from potentially biased local courts, are also fair game for analogical implementation despite the fact that Congress has never seen fit to impose them upon the tribes.

It should be obvious that bringing the Constitution to Indian country and promoting evolution of the federal common law of Indian affairs to harmonize it with our general law are radical steps that could disintegrate the established doctrines of federal Indian law. It is ironic, indeed, in a field in which the Court says that Congress has plenary power, that this destructive drive toward uniformity has taken place without any supporting congressional action. Indeed, the only recent congressional lawmaking directly involving the concerns of this Article-the legislation overturning Duro by acknowledging tribal authority to prosecute nonmember Indianswas motivated solely by a desire to undo a Supreme Court decision designed to make federal Indian law more uniform. It is ironic, as well, that this judicial shift has occurred in a time in which the express congressional and executive policy has been to promote, not undercut, tribal sovereignty.

Nor has the Court openly acknowledged that it has gone a long way toward abandoning its prior practices of using canons of interpretation to prevent all but congressionally mandated losses of tribal interests. In the reservation-diminishment cases and the implicit-divestiture cases like Bourland, where the Court purported to rely upon statutory or treaty text, it is hard to avoid the conclusion that the Court paid the canons lip service, but ended up embracing its sense of general congressional assimilative purposes where the context under litigation was seen as heavily non-Indian in nature. But note that the general congressional purposes in these cases relate to statutes adopted long ago, during a different era in federal-tribal relations, and represent obsolete congressional purposes as against current congressional and executive policies. Why should the Court prefer old purposes to new ones, especially where, as in all these cases, the statutory text does not compel any particular outcome and the canons favoring the protection of Indian interests have both a longstanding pedigree and a substantial basis in policy?

In the implicit-divestiture cases like Oliphant and Duro, where the Court has fallen victim to a "dormant plenary power impulse" to bring constitutional values to Indian country, the canons have played an even less significant role. The Court in these circumstances imposed such federal common-law rules where Congress has been essentially silent (Oliphant) and even where Congress has sent strong signals contrary to the judicial outcome (Duro). To the extent that the Court has considered nonconstitutional values as informing its authority to alter federal common 
law in this domain, as occurred in Strate, it has arrogated to itself even more power than was involved in Oliphant or Duro, for the Court seems to believe that all values found in general law, not just well-established constitutional values, are relevant to the new harmonization of federal Indian law. To put it bluntly, this approach suggests that, to the extent that federal Indian law is inconsistent with what law students learn in their required courses and foundational electives, federal Indian law is out of step and in need of reform. The current congressional and executive policies promoting tribal self-government are, apparently, irrelevant to this inquiry, except to the extent that they suggest to the Court that tribes have allies available who might be willing to overturn the Court once in a while and restore to tribes some authority that was judicially removed, as with the legislation effectively overruling Duro.

This technique turns federal Indian law on its head. The field is best understood as reflecting a stark compromise between colonialism (overriding power) and limited government (the rule of law): Congress has virtually untethered authority over Indian affairs, but the courts stand ready, through the canons of interpretation, to force Congress to do its ongoing colonial work expressly. ${ }^{363}$ The vagaries of existing law are interpreted to preserve tribal sovereignty, and those seeking to diminish tribal power must bear the burden of overcoming legislative inertia to obtain express congressional authorization. This approach provides the courts with a course to chart through the immense complexities of the field, preserves the status quo from the Indian perspective, and gives tribes and their allies fair notice and a meaningful chance to defeat proposals to implement colonization more broadly. The new harmonization threatens to jettison this well-established mediating method rooted in congressional responsibility and judicial checks in favor of a one-sided imposition of colonial values where courts, not Congress, assume front-line colonial responsibility.

If the judges borrow concepts from the general law, not simply from constitutional values and general congressional purposes associated with particular statutes, the uniqueness of federal Indian law may evaporate. In a decade or two, law schools may have no reason to offer a course in "Federal Indian Law"; instead, it might be enough to teach a chapter called "Indian Lands" in a casebook on public lands and natural resources. Tribes will have lost all sovereignty and, from the outside, might appear to be little more than ethnocentric Elks Clubs. To be sure, tribes and their members will endure as best they can. But even if the doctrinal drift alone is unlikely

363. See Frickey, supra note 22, at 406-17. 
to revive the nineteenth-century non-Indian notion of the "vanishing Indian," 364 it is the harbinger of the vanishing Indian law.

Of course, nothing like a complete collapse of federal Indian law into the broader public law has yet occurred. What I have described is merely a trend that the Court itself has embarked upon without evident reflection. Particularly in a field as slippery and complicated as federal Indian law, a host of choices remains viable. In the next Part, this Article concludes by briefly examining some of them.

\section{CONCLUSION: SOME ALTERNATIVES TO THE NEW HARMONIZATION OF FEDERAL INDIAN LAW}

The end of a lengthy article is hardly the place to examine with requisite care the choices available to Congress and the Supreme Court in this second quincentennial of the colonization of this continent. Instead, what $I$ hope to do is merely suggest some of the plausible avenues open to these institutions in addressing what seems to be the root problem in the cases involving judicial diminishment of tribal authority: the presence of nonmembers in Indian country.

In many respects, the simplest option for the Court would be to freeze the law as it now stands, embrace what it can retrieve of the traditional concepts, and force Congress to undertake any further relief for nonmembers in Indian country. This approach would leave the doctrines incoherent-it would maintain precedents favoring tribal sovereignty like Williams and Merrion, while likewise entrenching nonmember-protecting precedents like Oliphant and Montana. Any real freezing of the doctrinal status quo would have to avoid more decisions like Bourland and Strate, which refused to find rather evident distinctions between their facts and prior precedents. ${ }^{365}$ Such a judicial change of direction might seem unfair to nonmembers, who have been able to convince courts of the injustice of tribal regulation on a case-by-case basis. But a fundamental problem with the Court's new common law of colonization is that it relieves Congress of its responsibility to visit these issues. A further problem is that the disputes come up in a concrete litigative situation in which an abstract and poorly

364. On this myth, see, for example, BRIAN W. DIPPIE, THE VANISHING AMIERICAN: WhITE ATTITUDES AND U.S. INDLAN POLICY (1982); and Rober N. Clinton, Redressing the Legacy of Conquest: A Vision Quest for a Decolonized Federal Indian Law, 46 ARK. L. REv. 77, 79-80 (1993).

365. The outcome in Bourland could easily have been avoided by interpreting Oliphant and Duro as metely involving tribal criminal authority and Monsana as mercly involving tribal civil regulatory authority over nonmember fee lands. These limiting interpretations would then have freed the Court in Strate to consider National Farmers and lowa Murual as the authoritative precedents concerning tribal-cour jurisdiction over nonmember defendants, and to conclude that Montana had no relevance there, because the conduct of the nonmember defendant in question occurred outside nonmember fee land. 
understood concept with little cross-cultural currency - tribal sovereigntyis weighed against perceived real hardship to an identified individual with whom the judges share more cultural affinity. It is no surprise how that balance has been struck in recent cases-that, to borrow from Holmes again, it is tribal sovereignty, not the presence of nonmembers in Indian country, that strikes judges as an "accidental relic of an early notion." But the fundamental question is which institution should be attempting to strike the balance in the first place. Under our longstanding assumptions in the field, that institution should be Congress, not the Court. ${ }^{366}$ The only way that Congress is likely to take on these matters is if the Court retrocedes to it front-line responsibility for them. ${ }^{367}$

To divert the Court from its doctrinal drift, such considerations of comparative institutional competence are probably paramount, but other factors are also relevant. Most fundamentally, the Court is unlikely to take a more favorable view of tribal sovereignty in the contemporary context without being presented with a salient argument for following the traditional constructs of the Marshall Court that transcends a mere exhortation to adhere to the formalisms of hoary precedent. ${ }^{368}$ At bottom, the Court needs a contemporary comfort level with the proposition that tribes are governments, not voluntary membership associations; it is surely discomfort with this conclusion that has led the Court to impose a creeping constitutionalism in federal Indian law. There is no escaping the normative character of any defense of tribal sovereignty along these lines, ${ }^{369}$ although practical factors, such as scholarship indicating that economic development in Indian country works best when tribes are capable of autonomous sovereignty, make the case as well. ${ }^{370}$

366. See Getches, supra note 22, at 1573-76.

367. Cf. Minnesota v. Mille Lacs Band of Chippewa Indians, 119 S. Ct. 1187 (1999) (declining to construe a treaty or an executive order as abolishing tribal off-reservation hunting. fishing, and gathering rights); Kiowa Tribe v. Manufacturing Techs., 118 S. Ct. 1700, 1705 (1998) (refusing to abolish tribal sovereign immunity by judicial decision, and instead leaving the issue for Congress).

368. See Frickey, supra note 68, at 1204-09.

369. In earlier work, I have attempted to make the case that, at a minimum, the opponents of tribal sovereignty bear the burden of argumentative persuasion today. A major prece of the defense of a baseline of tribal authority is based on a conceptualization of the Marshall Court precedents as attempts to mediate colonialism and constitutionalism rather than simply to privilege the former. See Frickey, supra note 22; supra text accompanying notes 54-60. More fundamentally, I have suggested that our traditions of limited government, consent of the governed, and respect for autonomy are simply incompatible with our historical and contemporary unilateral displacement of indigenous persons. Today, the international community almost universally condemns future acts of colonization. The failure of policies such as allotment demonstrates that practical concems support the autonomy of tribes as well. See Frickey, supra note 23 , at $48 \&$ n.71.

370. See Stephen Cornell \& Joseph P. Kalt, Reloading the Dice: Improving the Chances for Economic Development on American Indian Reservations, in WHAT CAN TRIBES DO? STRATEGIES AND INSTITUTIONS IN AMERICAN INDIAN ECONOMIC DEVELOPMENT (Stephen Cornell \& Joseph P. Kalt eds., 1995). 
What might Congress do in response to the agonizing problems faced both by tribes and nonmembers, as well as by states that have potentially overlapping jurisdiction with tribes? No doubt tribal leaders would do their best to prevent Congress from further diluting tribal sovereignty, and no one should begrudge them that effort. If Congress is bestirred to attempt to achieve a principled compromise, however, it should encourage a wide scope to the imagination of good-faith advocates for all sides. Consider a few possibilities, which I offer merely as illustrations of places where such a conversation might begin.

If Congress deemed tribal courts to be inferior institutions to adjudicate claims against nonmembers, it might consider increasing federal funding and other supportive measures for these courts. Perhaps the quid pro quo could be a limited federal appellate review, akin to certiorari, from the highest tribal court to the Supreme Court, to the federal court of appeals for that circuit, or to a special Court of Appeals for Indian Affairs. ${ }^{371}$

Another possibility would be the enactment of an "Unallotment Act." Bruce Duthu once imagined such a federal statute that would provide that, after the passage of a certain amount of time, perhaps a decade, all nonmembers who remain in Indian country would be subject to full tribal territorial sovereignty. ${ }^{372}$ Duthu acknowledged the political implausibility of the proposal, ${ }^{373}$ but there may be more politically feasible revisions to the idea. For example, Congress might provide the tribe with a right of first refusal concerning any transfer of fee simple land within the reservation, so that the tribe would have the privilege of purchase. Of course, for most tribes, funds are not readily available for such an effort, and thus Congress would have to provide financial assistance. A more aggressive program would recognize a tribal power of eminent domain concerning fee simple reservation land. ${ }^{374}$ As a matter of compromise, Congress could limit such

371. See, e.g., Robert N. Clinton, Tribal Courts and the Federal Union, 26 WILLAMETTE L. REV. 841, 889-94 (1990) (exploring, but not necessarily endorsing, such options). For the argument that a dialogue between tribal courts and the state and federal courts would more productively advance fair and efficient adjudication respectful of tribal sovereignty than would litigation in the federal courts about the capacities of tribal judiciaries, see B.J. Jones, IVelcoming Tribal Courts into the Judicial Fraternity: Emerging Issues in Tribal-State and Tribal-Federal Court Relations, 24 WM. MTCHELL L. REV. 457 (1998).

372. See N. Bruce Duthu, Implicit Divestiture of Tribal Powers: Locating Legitimate Sources of Authority in Indian Country, 19 AM. INDLAN L. REV. 353, 399-400 (1994). Duthu's article presents a good overview of the implicit-divestiture cases as well as a realistic perspective upon potential responses to them.

373. See id at 400.

374. Authorizing the tribe to exercise a power of eminent domain would seem similar to acknowledging tribal civil regulatory authority, which was upheld in Mazurie. See supra text accompanying notes $154-157$. If Congress may authorize eminent domain, it might very well have the lesser-included power of authorizing a right of first refusal to the tribe. One imporant fearure of both of these proposals is that the nonmember landowner would receive fair market value for the land. For one recent congressional proposal to promote land consolidation on reservations, see H.R. 4325, 105th Cong. (1998). 
programs to reservations, or portions of reservations, where land consolidation seems most feasible. Interestingly, such efforts may have a significant chance of success on some Indian reservations today, which because of depopulation trends by non-Indians have an increasingly "Indian character." 375

At bottom, the issues seem to be more about political economy than law. Indeed, the Court itself has engaged in its own brand of amateur political economy in recent years, evaluating demographics and land ownership patterns in deciding whether reservation boundaries should be diminished and whether tribal authority should remain over nonmembers concededly found within the reservation. In light of the doctrinal confusion and practical chaos that these lines of cases have produced, however, it strikes me as fruitful to shift the intellectual debate in federal Indian law in order to spark the imagination of professional political economists and to dampen the influence of litigation. ${ }^{376}$ The only institution capable of encouraging such innovation designed to find local solutions to local problems is Congress-and to do so it would itself need to avoid one-sizefits-all statutory solutions and instead provide incentives for the play of imagination and bargaining.

Of course, many other legislative possibilities exist, including some that would seriously intrude upon or even terminate tribal sovereignty. ${ }^{377}$

375. See BoRDEWICH, supra note 6, at 342 (referring to the Great Plains as a "region for the most part so ill-suited to modern development that the descendants of the settlers who muscled the Indians off in the nineteenth century have largely abandoned it themselves").

376. See Frickey, supra note 11, at 1777-84.

377. One obvious example would be the granting of some sort of voting rights to nonmembers. This solution might make sense on some reservations, but I would hope that it would be accomplished by voluntary compromise by the tribe, not through unilateral congressional action. Related strategies might include allowing nonmembers to serve on juries and constructing approaches to shared governance for limited-purpose institutions. For discussion of one such innovative arrangement, see Utah Department of Community and Economic Development, 1997 Annual Report-Uintah Basin Revitalization Fund (visited Mar. 16, 1999) <http://www.ce.ex.state.ut.us/annrep97/ubrf.html>, which describes a five-member boardconsisting of a governor's designee, one county commissioner each from the two affected counties, and two representatives of the Ute Indian Tribe's Business Committee-that distributes revenue from the state severance tax imposed upon the extraction of minerals on tribal trust lands in grants to agencies of county or tribal government working to benefit those who are socially or economically affected by this oil and gas development. For an overview of an innovative bilateral agreement concerning shared governance by the federal government and a tribe, see Charles Wilkinson, The Role of Bilateralism in Fulfilling the Federal-Tribal Relationship: The Tribal Rights-Endangered Species Secretarial Order, 72 WASH. L. REV. 1063 (1997): and Carl H. Johnson, Note, Balancing Species Protection with Tribal Sovereignty: What Does the Tribal Rights-Endangered Species Order Accomplish?, 83 MINN. L. REv. 523 (1998). On jurisdictional agreements between states and tribes, see, for example, P.S. Deloria \& Robert Laurence, Negotiating Tribal-State Full Faith and Credit Agreements: The Topology of the Negotiation and the Merits of the Question, 28 GA. L. REV. 365, 373-74 (1994); David H. Getches, Negotiated Sovereignty: Intergovernmental Agreements with American Indian Tribes as Models for Expanding Self-Government, 1 REV. CONST. STUD. 120, 121 (1993); Rebecca Tsosie. Negotiating Economic Survival: The Consent Principle and Tribal-State Compacts Under the Indian Gaming 
Colonialism is a dangerous political game, and congressional considerations of these problems could go in a variety of directions, some of them devastating to tribes. In anticipation of such possibilities, there are those of us in the academy who would provide some judicially enforceable side constraints upon unilateral congressional colonial action. ${ }^{378}$ For present purposes, however, it seems sufficient to note what the examination of Supreme Court decisions in this Article has demonstrated: that any effort to mediate the tension between tribes and nonmembers in Indian country is inherently political and not easily subject to judicial balancing and resolution. Dialogue and compromise among sovereigns-Congress, tribes, and states, which have incentives to provide an effective voice to nonmembers-are likely to be superior methods of achieving anything remotely approaching a lasting solution in this context of multi-sided and sharply contrasting visions of "accidental relics of early notions" and "felt necessities of the time." What makes sense is a constructive conversation, not a common law, for our age of colonialism.

Regulatory Act, 29 ARZ. ST. L.J. 25. 59 (1997); and Note, Intergovemmental Compacts in Native American Law: Models for Expanded Usage, 112 HARV. L. REV. 922 (1999).

378. For my argument, see Frickey, supra note 23. 
